\title{
Effects of different dietary oil sources on growth performance, antioxidant capacity and lipid deposition of juvenile golden pompano Trachinotus ovatus
}

Haoji Guo ${ }^{1 \dagger}$, Cuiying Chen ${ }^{1 \dagger}$, Xin Yan $^{1}$, Yuanyou Li², Xiaobo Wen ${ }^{1,2}$, Cuihong You ${ }^{1}$, Óscar Monroig ${ }^{4}$, Douglas R. Tocher ${ }^{1,5}$, Shuqi Wang ${ }^{1,3 *}$

Affiliations:

${ }^{1}$ Guangdong Provincial Key Laboratory of Marine Biotechnology \& Research Center for Nutrition \& Feed and Healthy Breeding of Aquatic Animals, Shantou University, Shantou 515063, China

${ }^{2}$ School of Marine Sciences, South China Agricultural University, Guangzhou 510642, China

${ }^{3}$ Southern Marine Science and Engineering Guangdong Laboratory, Guangzhou 511458, China

${ }^{4}$ Instituto de Acuicultura Torre de la Sal, Consejo Superior de Investigaciones Científicas (IATS-CSIC), 12595 Ribera de Cabanes, Castellón, Spain

${ }^{5}$ Institute of Aquaculture, Faculty of Natural Sciences, University of Stirling, Stirling FK9 4LA, Scotland, UK

*Corresponding Author

Shuqi Wang, Ph.D. (E-mail: sqw@stu.edu.cn; Tel: 0754-86500614)

${ }^{\dagger}$ These authors contributed equally to this work. 


\section{Abstract}

Vegetable oils (VO) that are used to substitute fish oil in aquafeeds may affect, not only the fatty acid composition, but also lipid metabolism and distribution. The present study was designed to investigate this issue in juvenile golden pompano Trachinotus ovatus fed eight diets formulated with typical VO with widely varying fatty acid compositions including coconut oil (CO), palm oil (PO), oil-tea camellia seed oil (OTO), olive oil (OO), canola oil (CNO), peanut oil (PNO), linseed oil (LO) and perilla oil (PFO), in comparison with fish fed fish oil (FO). After the 8-week feeding trial, fish fed the CO diet had the highest growth performance, and higher general antioxidant capacities in serum and liver than in fish fed the other VO. The crude lipid content in whole body and expression levels of fas were lower in fish fed the FO, PFO and LO diets, while lipid contents and expression levels of $s c d$ were higher in fish fed the OTO and PNO diets. Other than fish fed the PFO diet, the total lipid contents of liver in other fish fed the other VO diets were higher than that in fish fed the FO diet, with the highest contents in fish fed the OTO and OO diets. The expression levels of genes involved in fatty acid catabolism and transport, namely ppara, cpt1 and apoB100, were higher in fish fed diet PFO than in fish fed the other diets. Comparing the fatty acid compositions of tissues and diets showed that 18:1n-9, 18:3n-3 (ALA) and 22:6n-3 (DHA) were preferentially deposited in tissues of pompano, with DHA preferentially deposited in polar lipids rather than neutral lipids. However, excessive dietary ALA in PFO did not lead to increased deposition of ALA, but increased liver lipid content. The present study showed that dietary lipid sources had significant influences on growth performance and antioxidant capacity, as well as on lipid deposition. Low dietary 18:1n-9, high n-3 longchain polyunsaturated fatty acids and an appropriate ratio of ALA/LNA (18:2n-6) could reduce lipid deposition in pompano tissues, especially liver.

Keywords: Trachinotus ovatus, lipid sources, vegetable oils, growth performance, lipid deposition 


\section{Introduction}

In recent decades, the farming of aquatic organisms has been the fastest growing animal protein and food producing sector, supplying over $50 \%$ of global fish and seafood for human consumption (Sprague et al., 2017). In consequence, the design and manufacture of aquafeeds for marine animal species will continue to be a key cornerstone in the future development of sustainable fish farming. Fish oil has been a traditional and popular raw material for the supply of dietary lipids in aquafeeds, providing excellent nutritional value (Sun et al., 2011). In particular, fish oil is rich in n-3 long-chain polyunsaturated fatty acid (n-3 LC-PUFA) including eicosapentaenoic acid (EPA, 20:5n-3) and docosahexaenoic acid (DHA, 22:6n-3), which are essential nutrients with important roles in many physiological and biochemical processes, including immune and anti-inflammatory responses, and nervous system development among others (Firat et al., 2017; Li et al., 2020a). However, on an annual basis, fish oil is a finite natural resource and its supply has reached its sustainable limit, and so increasing demand has resulted in prices rising year on year (Turchini et al., 2011a). Therefore, finding sources of appropriate oils to replace dietary fish oil has been a subject of considerable research interest for many years (Turchini et al., 2009, 2011b). The research results have encouraged the global aquaculture industry to consider a spectrum of potential lipid sources as alternatives to marine oils, with increasing proportions of fish oil being replaced by alternative oils resulting in increased sustainability and economic viability of fish farming (Ytrestøyl et al., 2015; Aas et al., 2019).

The main alternatives to fish oil that have been extensively evaluated in various fish species in recent years are vegetable oils (VO) that, although being devoid of the n-3 LC-PUFA, EPA and DHA, can offer a wide range of different fatty acid compositions. Among others, potential alternative VO include coconut oil, palm oil, canola, olive oil, camellia (tea) seed oil, peanut oil, linseed oil and perilla oil. Coconut oil, enriched in up to $45 \%$ lauric acid (12:0), has shown potential to stimulate growth and health of some fish species, such as yellow catfish Pelteobagrus fulvidraco (Lu et 
al., 2018). Palm oil, the second largest edible oil in the world by volume with a lower price than other VO, is enriched in palmitic acid (16:0) and can replace dietary fish oil in some fish species with no negative impacts on growth performance or feed utilization (Naing et al., 2007). Both olive and camellia seed oils are enriched in oleic acid (18:1n9) up to almost $80 \%$, and have similar physicochemical properties that are highly suitable for use in aquafeeds (Preedy et al., 2011). Although generally no negative impacts on growth of fish fed olive oil or camellia seed oil were observed, liver lipid contents were increased in some fish species, such as yellowtail Seriola quinqueradiata (Seno et al., 2008) and hybrid tilapia Oreochromis niloticus $\times$ O. aureus (Han et al., 2012). Canola (or rapeseed) oil contains not only a high content of 18:1n-9 but also abundant linoleic acid (LNA, 18:2n-6) along with other minor lipid compounds such as phytosterols and tocopherols, and also affects lipid metabolism in fish (Pettersson et al., 2010). Peanut oil, also rich in 18:1n-9 and LNA, has been used to replace fish oil without obvious impacts on growth performance in several species of fish, including juvenile African catfish Clarias gariepinus (Zaid and Akinremi, 2009), Mozambique tilapia O. mossambicus (Demir et al., 2014) and two-banded seabream Diplodus vulgaris (Osman et al., 2016). Linseed oil and perilla oil, which contain abundant $\alpha$ linolenic acid (ALA, 18:3n-3), have been regarded as functional lipid sources, having the ability to modulate lipid metabolism in Atlantic salmon (Salmo salar) (Bell et al., 2003; Bell et al., 2004) and South American catfish Jundiá (Rodrigo et al., 2008). Compared to other VO, linseed and perilla oils had positive effects on n-3 PUFA deposition in Nile tilapia O. niloticus (Dos et al., 2014), rainbow trout Oncorhynchus mykiss (Wijekoon et al., 2014) and Japanese seabass Lateolabrax japonicus (Xu et al., 2015), contributing to increased nutritional value.

In terms of fatty acid composition, the VO can be classified into four groups, depending upon whether they are enriched in saturated fatty acids (SFA), monounsaturated fatty acids (MUFA), n-6 PUFA or n-3 PUFA. Studies have shown that diets rich in the different fatty acid groups can have differential effects on the fatty acid compositions of different tissues (liver and muscle) and, in some cases, can significantly affect fish fillet quality and health (Martínez-Lorens et al., 2007; Menoyo 
et al., 2004; Mourente et al., 2005). However, whether VO containing similar fatty acid groups/compositions have entirely similar effects on growth performance and lipid metabolism including deposition in different tissues, particularly liver and flesh, requires further research.

The golden pompano, Trachinotus ovatus, belongs to the Carangidea family, and is a euryhaline species able to thrive in both seawater and brackish water (Tutman et al., 2004). It is highly regarded by consumers who appreciate its delicious, delicate taste and the fact its fillet has few small bones. In addition, golden pompano displays rapid growth and is easy to handle and, therefore, is a highly farmed fish in south-eastern China with important economic value (Tan et al., 2017). Golden pompano is omnivorous but with a carnivorous tendency and has been the subject of considerable research into various aspects of culture including nutrient requirements (Tang et al., 2013) such as optimum levels of dietary protein (Ma et al., 2014) and lipid (Wang et al., 2013; Li et al., 2020b), dietary additives (Zhou et al., 2015), stocking density and stress. In addition, high PUFA contents in muscle make golden pompano an interesting species in which to investigate the impacts of different dietary VO in marine fish (Sun et al., 2018). One study showed that pompano fed dietary soybean and corn oils (both rich in LNA and to a lesser extent 18:1n-9) showed significantly lower specific growth rate and muscle lipid content than fish fed a diet with fish oil (Li et al., 2019). Another study reported that fish fed soybean oil or lard showed increased lipid content of whole body, liver and muscle (Liu et al., 2018). These contradictory results suggest that little is known about the effects of dietary lipid substitution and, particularly, their impacts on lipid metabolism and tissue fat deposition in golden pompano.

The aims of the present study were to evaluate the effects on growth performance, tissue fat distribution and lipid oxidation resistance in golden pompano fed eight VO with a range of fatty acid compositions, in comparison with fish fed a fish oil diet as the control, in order to determine appropriate lipid sources as alternatives to dietary fish oil. The results of the study provide reference data and a theoretical basis for the formulation of feeds with fatty acid compositions balanced to promote the health of 
marine fish.

\section{Materials and methods}

\subsection{Experimental diets}

Nine isoproteic ( $45.7 \%$ crude protein) and isolipidic $(\sim 12.5 \%$ total lipid) experimental diets were formulated to contain different lipid sources, specifically coconut oil (CO), palm oil (PO), oil-tea camellia seed oil (OTO), olive oil (OO), canola oil (CNO), peanut oil (PNO), linseed oil (LO) and Perilla frutescens seed oil (PFO) with a fish oil diet (FO) as a control. The dietary ingredients, proximate compositions and fatty acid compositions are detailed in Table 1. All dry ingredients were ground into fine powder, and micro components such as mineral and vitamin premixes added followed by lipid and distilled water $(20 \%, w / w)$. Ingredients were blended thoroughly by hand, before pellets ( $4 \mathrm{~mm}$ and $5 \mathrm{~mm}$ diameter) were produced using an automatic pelleting machine (SLC-45, Fishery Machinery and Instrument Research Institute, China). Pellets were air-dried to approximately $10 \%$ moisture, after which the diets were stored at $-20{ }^{\circ} \mathrm{C}$ until use.

\subsection{Experimental fish and feeding procedure}

The feeding trial with golden pompano T. ovatus was conducted at the Nan Ao Marine Biology Station (NAMBS) of Shantou University, Southern China. A total of 810 juvenile pompano were obtained from a local commercial farm in Zhangzhou, Fujian, China and fed a mixture of equal proportions of all nine experimental diets for two weeks to acclimatize to the experimental conditions. At the end of this period, fish were fasted for $24 \mathrm{~h}$ and weighed after being anesthetized with $0.01 \% 2-$ phenoxyethanol (Sigma-Aldrich, USA). Fish (initial weight $10.6 \pm 0.2 \mathrm{~g}$ ) were randomly distributed into 27 floating net cages $(1.0 \mathrm{~m} \times 1.0 \mathrm{~m} \times 1.5 \mathrm{~m})$, with 30 fish per cage and 3 cages per diet. Twice a day (6:30 and 17:00), the fish in each cage were hand-fed carefully to ensure feeding to obvious satiation and the feeding trial lasted for 
8 weeks. Mortalities were collected, recorded and weighed throughout the trial. The sea water temperature was $10.5-20.0^{\circ} \mathrm{C}$, salinity was 33 - 35 ppt and dissolved oxygen was $7 \mathrm{mg} \cdot \mathrm{L}^{-1}$.

\subsection{Sample collection}

At the end of the feeding trial, fish were fasted for $24 \mathrm{~h}$ prior to sample collection. All fish in every net gage were anaesthetized with $0.01 \%$ 2-phenoxyethanol (SigmaAldrich, USA), counted and weighed individually. Anaesthetized fish were euthanized by a blow to the head prior to collection of the appropriate fish and tissue samples. Three fish were randomly collected from each net cage and stored at $-20^{\circ} \mathrm{C}$ for whole body composition analysis. A sample of blood was collected by heparinized syringe from the caudal vasculature of 3 fish randomly collected per net cage and held at $4{ }^{\circ} \mathrm{C}$ for $6 \mathrm{~h}$ prior to centrifugation (4000 g, $10 \mathrm{~min}$ ). The serum obtained was stored at $20{ }^{\circ} \mathrm{C}$ in $2 \mathrm{~mL}$ sterile tubes (Axygen, USA) until used for the measurement of biochemical and antioxidant indices. Samples of liver, dorsal muscle, and abdominal muscle were collected in $2 \mathrm{~mL}$ sterile tubes (Axygen) from another 3 fish per net gage and stored at $-80^{\circ} \mathrm{C}$ prior to lipid and fatty acid analyses. A further sample of liver was collected from these fish and snap frozen for analysis of genes involved in lipid and fatty acid metabolism. Liver and whole viscera of all sampled and dissected fish were weighed for determining hepatosomatic (HSI) and viscerosomatic (VSI) indices.

\subsection{Proximate and fatty acid compositions}

The proximate compositions (protein, lipid, ash and moisture contents) of diets and whole fish were determined according to standard methods (AOAC, 2006). For fatty acid analysis, total lipid was extracted from samples of diets, liver, dorsal muscle and ventral muscle by extracting with chloroform / methanol $(2: 1, \mathrm{v} / \mathrm{v})$ containing $0.01 \%$ butylated hydroxytoluene (BHT) as antioxidant according to the method of Folch et al. (1957). Total lipids of fish tissues were fractionated into total neutral and polar lipids by chromatography using Sep-Pak ${ }^{@}$ Vac 6cc (500 mg) silica cartridges (Waters, 
Ireland). Neutral lipids were eluted with chloroform $(30 \mathrm{~mL})$ and polar lipids with methanol (30 mL) as described by Belaunzaran et al. (2017), and fatty acid methyl esters of these fractions were prepared as follows. Lipids were saponified with $0.5 \mathrm{M}$ potassium hydroxide in methanol before transesterification with boron trifluoride methanol (ca. $14 \%$; Acros Organics, NJ, USA). Fatty acid methyl esters were separated by gas chromatography (GC-2010 plus; Shimadzu, Kyoto, Japan) equipped with an auto-sampler and a hydrogen flame ionization detector as described in detail previously (Li et al., 2010). Individual fatty acids were identified by comparison with known commercial standards (Sigma-Aldrich, St. Louis, MO, USA) and quantified with GCsolution workstation (Shimadzu, Kyoto, Japan).

\subsection{Serum biochemical indices}

Serum samples were assayed within $24 \mathrm{~h}$ after collection and storage at $4{ }^{\circ} \mathrm{C}$. Contents of total protein (TP), high-density lipoprotein (HDL), low-density lipoprotein (LDL), triglyceride (TG), total-cholesterol (T-CHO) and non-esterified fatty acid (NEFA), and activities of alanine aminotransferase (ALT) and aspartate aminotransferase (AST) were determined using commercial assay kits (Nanjing Jiancheng Bioengineering Institute, China). All the enzymatic activities and nonenzymatic factor contents were calculated according to the manufacturer's instructions.

\subsection{Antioxidant indices in serum and liver}

Serum samples were assayed within $24 \mathrm{~h}$ of collection after storage at $4{ }^{\circ} \mathrm{C}$. Hepatic samples were homogenized in ice-cold physiological saline $0.89 \%$ (w/v) buffer, and the homogenate centrifuged for $20 \mathrm{~min}$ at $800 \mathrm{~g}$ to collect the supernatant. The content of malondialdehyde (MDA) in serum and liver supernatants was determined using assay kits (Nanjing Jiancheng Bioengineering Institute, China). The activities of serum and liver glutathione peroxidase (GSH-PX), catalase (CAT), superoxide dismutase (SOD), and total antioxidant capacity (T-AOC) were determined 
using commercial assay kits (Nanjing Jiancheng Bioengineering Institute). All the enzymatic activities and nonenzymatic factors were calculated according to the manufacturer's instructions.

\subsection{Real time quantitative PCR}

Total RNA from liver was isolated using RNAprep pure Tissue $\mathrm{Kit}^{\circledR}$ (Tiangen, China) according to the manufacturer's instructions. The RNA quality was assessed by formaldehyde agarose gel electrophoresis, and the concentration of RNA was quantified by A260/A280 ratio (between 1.8 and 2.0) by spectrophotometry (NanoDrop 2000, Thermo Fisher, Germany). The reverse transcriptase reaction was performed using a FastQuant ${ }^{\circledR}$ RT kit (Tiangen) including a genomic DNA elimination reaction. Quantitative real time PCR (qPCR) was carried out on a LightCycler ${ }^{\circledR} 480$ thermocycler (Roche, Germany) in a total volume of $20 \mu \mathrm{L}$ with $10 \mu \mathrm{L}$ SYBR Green I Master (Roche), $7 \mu \mathrm{L} \mathrm{ddH}_{2} \mathrm{O}, 1 \mu \mathrm{L}$ of each primer $(10 \mu \mathrm{M})$, and $1 \mu \mathrm{L}$ of diluted cDNA $\left(200 \mathrm{ng} \mu \mathrm{L}^{-1}\right)$. The qPCR program followed the manufacturer's protocol and all amplification reactions were run in triplicate. The specificity and efficiency of the primers for the $\beta$ actin (reference gene) and target genes were determined by constructing a standard curve using serial dilutions of cDNA. The expression levels of the target genes were calculated using the $2^{-\Delta \Delta \mathrm{Ct}}$ method with fish fed the control diet (FO) used as the reference group. The specific primers of the reference and target genes were as follows: B -actin, sense TACGAGCTGCCTGACGGACA and antisense GGCTGTGATCTCCTTCTGC; fatty acid synthase (fas), sense GAAGGAGAGGGGGTGGAGTC and antisense GTGTGAAGGTGGAGGGTGTG; stearoyl-CoA desaturase $(s c d)$, sense CCTTTTACGGCGTGTTCG and antisense TGGGGTTGATGTTCTTGT; peroxisome proliferator-activated receptor alpha (ppar $)$, sense AATCTCAGCGTGTCGTCTT and antisense GGAAATGCTTCGGATACTTG; carnitine palmitoyltransferase I (cpt1), sense CTTTAGCCAAGCCCTTCATC and antisense CACGGTTACCTGTTCCCTCT; 
apolipoprotein B100 (apoB100), sense AAAAGCCACAAGACGAAAGCA and antisense GAAGCAGCAAAAGGCAGAGC.

\subsection{Calculations and statistical analysis}

Data were presented as means \pm S.E. ( $n$ value as indicated). All data were subjected to one-way analysis of variance (ANOVA), and comparisons among the treatments were determined by Tukey's multiple range test at the $P<0.05$ level of significance using SPSS version 25.0 (SPSS Inc., Chicago, IL, USA).

\section{Results}

\subsection{Growth performance and feed efficiency}

The growth performance and feed efficiency of juvenile pompano T. ovatus fed the experimental diets are shown in Table 2. Neither survival rate (SR) nor feed conversion ratio (FCR) showed any statistical differences among the dietary treatments. Of the fish fed the VO diets, only fish fed diets CO and PFO showed slightly better growth performance values than fish fed the FO diet, with numerically higher final weights, weight gain (WG) and specific growth rate (SGR), although the data were not statistically significant. Within the VO diets, fish fed the CO and PFO diets had significantly better growth performance with higher final weights, WG and SGR than fish fed diet PO. Fish fed the CO diet had significantly higher VSI than fish fed the FO diet, while fish fed both CO and PO diets had significantly higher HSI than fish fed FO. Fish fed the OTO diet also had significantly higher condition factor (CF) than fish fed FO.

\subsection{Proximate composition of whole body}

The proximate compositions of whole body of juvenile pompano fed the experimental diets are shown in Table 3. Fish fed the PO diet had a lower protein content than fish fed the FO diet and all other diets except diet CO. The highest levels 
of total lipid were found in pompano fed the OTO and PNO diets, which were significantly higher than fish fed the control FO diet and diet PFO. Ash content in pompano fed the $\mathrm{CNO}$ diet was significantly higher than in fish fed the $\mathrm{CO}$, OTO and LO diets. Moisture contents did not show any significant differences among the experimental groups.

\subsection{Biochemistry indexes in serum}

As shown in Table 4, HDL tended to be higher, and LDL lower, in fish fed the FO diet compared to fish fed the VO diets, but this was generally not statistically significant other than LDL being significantly higher in fish fed the OTO and OO diets compared to fish fed all other diets. Serum concentrations of TG and T-CHO did not show any statistical differences among the dietary treatments, but pompano fed the $\mathrm{CO}$ and PO diets had significantly lower NEFA concentration than fish fed the other diets. Pompano fed the LO diet had significantly higher serum ALT activity than fish fed all the other diets, and lower AST activity than fish fed the other diets, significantly so in the case of fish fed the OTO, OO and PO diets.

\subsection{Antioxidation parameter in serum and liver}

Antioxidation parameters in serum and liver of juvenile pompano fed the experimental diets are shown in Table 5. Serum MDA level in fish fed the PNO diet was significantly lower than in fish fed diets PO, FO and LO, while liver MDA levels were generally higher in fish fed the PO and LO diets. The GSH-PX activity showed similar trends in serum and liver, with fish fed the VO diets, other than diet $\mathrm{CO}$, having significantly lower activity than fish fed the FO diet. The significantly lowest activity of CAT in serum was observed in fish fed diet PO and, in liver, CAT activity was also lowest in fish fed diet PO, significantly so in fish fed the FO, CO, PNO and PFO diets. Compared with fish fed the FO diet, SOD activity in serum was lower in fish fed the PNO diet, while SOD activity in liver was generally higher in fish fed the CO and OTO diets, and lower in fish fed the OO diet. In serum, pompano fed the FO, CO and PFO 
diets had significantly higher T-AOC activity than fish fed the PNO diet, while fish fed diet PNO had significantly higher T-AOC activity in liver than fish fed the OO diet.

\subsection{Total lipid contents of tissues}

Irrespective of diet, lipid content was highest in the liver, and lowest in dorsal muscle, with ventral muscle showing intermediate levels, and diet had differential effects on the distribution of lipid in the different tissues considered (Fig. 1). Liver lipid contents were significantly higher in fish fed all the VO diets, other than diet PNO, with highest lipid contents in fish fed the OTO, OO and PFO diets. Diet had less impact on lipid content of dorsal muscle with only fish fed the OTO and OO diets showing higher lipid contents than fish fed the control FO diet. In general, the VO diets reduced the lipid content of ventral muscle compared to fish fed the control FO diet, with fish fed the $\mathrm{CO}, \mathrm{PO}$ and $\mathrm{CNO}$ diets showing significantly lower lipid contents than fish fed the other diets. The contents of neutral lipid (NL) and polar lipid (PL) showed the same trend as total lipids in fish fed all the diets (Table 6). The ratio of NL/PL was not significantly affected by diet but, overall, it was higher in the muscle than in the liver, other than in fish fed the LO diet.

\subsection{Fatty acid composition of neutral or polar lipid in liver, dorsal muscle and ventral muscle}

The fatty acid compositions of NL in liver, dorsal muscle and ventral muscle are shown in Fig. 2 (detailed in supplementary table 1,2 and 3), and the fatty acid compositions of PL are shown in Fig. 3 (detailed in supplementary table 4, 5 and 6). The results showed that the specific fatty acid compositions of the different dietary oil sources were reflected in both the NL and PL fatty acid compositions of the tissues, but that the fatty acid compositions differed between the tissues. In particular, liver fatty acid compositions were different to those of dorsal and ventral muscles that had generally similar fatty acid compositions. However, the LC-PUFA, especially DHA, 
were preferentially deposited/retained in PL rather than NL in all tissues (Figs. 2 and 3, detailed in supplementary table 1, 2, 3, 4, 5 and 6).

\subsection{The expression of lipid metabolism-related genes in liver}

As shown in Fig. 4, the expression level of fas in liver was not significantly different in pompano fed the VO diets when compared to fish fed the FO diet. However, fish fed the OTO, OO and PNO diets had significantly higher fas expression level than fish fed the LO and PFO diets, while pompano fed the $\mathrm{CO}$ and PO diets had significantly higher $s c d$ expression level than fish fed the OO and PNO diets. The apoB100, cpt1 and ppara gene expression levels showed similar trends, with fish fed the control FO diet showing generally low levels, and fish fed the PNO diet showing higher levels than fish fed all the other diets other than fish fed diet LO in which apoB100 was similarly high.

\section{Discussion}

The present study has shown that dietary oil sources with different fatty acid compositions, as alternatives to fish oil, had specific impacts on growth performance in juvenile pompano T. ovatus. Our results on growth parameters and feed efficiency, which generally resulted in good performance of the VO in comparison to fish oil, suggested that juvenile pompano can efficiently use a variety of dietary VO sources to replace fish oil. It is interesting to note that, among the different types of VO tested, diets formulated with SFA-rich oils, namely CO (coconut oil is rich in 12:0) and PO (palm oil is rich in 16:0), had a remarkably different impact on fish growth, with CO fish having significantly higher SGR and WG compared to the PO diet fed fish. While previous studies have reported that palm oil's digestibility can be low in some fish (Turchini et al., 2009), and that pompano and other marine species efficiently utilize dietary coconut oil (oil source of CO diet) (Luo et al., 2014; Henderson, 1996), it is challenging to explain the growth results attending exclusively to the fatty acid composition. Rather, our analyses on MDA, a marker reflecting the degree of lipid 
peroxidation in the body and indirectly reflect the amount of cell damage (Peng et al., 2008), confirmed high concentrations in serum and liver suggesting increased peroxidation damage in pompano fed the PO diet, which could ultimately compromise growth performance in this experimental group. In agreement, compared to PO fish, both serum and liver of juvenile pompano fed the $\mathrm{CO}$ diet had high activities of SOD, CAT, GSH-PX and T-AOC, well-known antioxidant components that scavenge free radicals and reduce oxidative damage in fish (Sun et al., 2011). This may be explained by the fact that the coconut oil in the $\mathrm{CO}$ diet was produced by cold-pressing, a process that can preserve nutritional qualities by protecting minor components such as polyphenols (Kapilan, 2008), compounds with the ability to enhance the activity of antioxidant enzymes and eliminate excess free radicals in cells (Nevin et al., 2004, 2009). Unlike CO diet, relatively low activity levels of SOD, CAT and GSH-PX in pompano fed the PO diet may result in greater oxidative damage that suppressed growth of fish associated to impaired liver metabolism (Huang et al., 2008).

Many previous studies have shown that different dietary oil sources significantly affected whole body lipid contents of marine fish (Olsen et al., 2007). Consistently, juvenile pompano fed the FO, PFO and LO diets in this study had the lowest levels of total lipid in whole body. These were the diets particularly enriched in n-3 PUFA or LCPUFA, suggesting that dietary n-3 fatty acids had the potential to reduce total fat accumulation in body of juvenile pompano. In addition to whole body lipid composition, we also investigated the lipid content of particular tissues including liver, dorsal muscle and ventral muscle, since it is well known that the impact of different dietary oil sources on the precise distribution of lipid/fat in these tissues can have very important practical significance associated to product quality and fish health. In agreement with previous studies, juvenile pompano fed diets formulated with VO other than peanut oil (PNO diet) as substitutes for fish oil increased the lipid content of liver (e.g., Jordal et al., 2007; Menoyo et al., 2004). Often, such trend is also observed in muscle and thus dietary VO such as rapeseed, palm, linseed and olive oils also increased the lipid content in muscle of Atlantic salmon (Torstensen et al., 2011) and gilthead sea bream (Cruz-Garcia et al., 2011). However, in contrast, other studies suggested that the lipid 
content of liver, muscle and ventral adipose tissues were reduced by feeding VO including rapeseed, palm and linseed oils in Atlantic salmon (Nanton et al., 2007; Bell et al., 2001).

In agreement with previous reports (see Turchini et al., 2011b), the fatty acid composition of the dietary $\mathrm{VO}$ used in the present study mostly determined that of the fish tissues. However, our analyses revealed that pompano do not merely accumulate dietary fatty acids but rather metabolize actively some of them. Thus, it was interesting to note that the levels of $18: 1 \mathrm{n}-9$ in tissues were higher than in the diets other than in fish fed the OO and OTO diets, which had high concentrations of 18:1n-9. Since pompano, as any other teleost (Monroig et al., 2018), can convert 18:0, 16:0 or shortchain SFA to $18: 1 n-9$, such fatty acids and energy are consumed when 18:1n-9 was low in the diet. Perhaps as a result, the lipid content was highest in liver of pompano fed the OO and OTO diets. Similar results had been reported in Atlantic salmon (Torstensen et al., 2004) and yellowtail (Seno et al., 2008). Thus, diets like OO and OTO, enriched in MUFA, particularly 18:1n-9, have been shown to promote lipid accumulation in tissues of fish (Du et al., 2008). The results of gene expression also support this hypothesis, as mRNA levels of $s c d$, the gene encoding the stearoyl-CoA desaturase responsible for 18:1n-9 biosynthesis from 18:0 (Monroig et al., 2018), were lower in fish fed the OO and OTO diets, and correspondingly higher in fish fed the $\mathrm{CO}$ and PO diets. However, the expression of fas, encoding the fatty acid synthase complex responsible for 16:0 and 18:0 biosynthesis, did not increase significantly in fish fed the $\mathrm{CO}$ and PO diets.

The feeding trial further showed that pompano preferentially deposits DHA in polar lipids as suggested by the fact that, in addition to the FO group, the other dietary groups also maintained high levels of DHA in the liver and muscle. As many other marine fish, it is likely that pompano cannot convert ALA to DHA, so maintaining DHA levels may require depositing more lipid in tissues. Except for fish fed diets PNO, CO and LO, the total lipid content of liver in fish fed the other VO was higher than that in FO group. This is consistent with the results of many studies (Tocher, 2015), and may suggest a further underlying mechanism. Interestingly, pompano fed the diets enriched in SFA and, to a lesser extent, MUFA, had higher DHA contents in tissue polar lipids 
than fish fed the other diets, while fish fed diets enriched in n-3 PUFA and n-6 PUFA showed lower levels of DHA in polar lipid. This phenomenon has been explained by the fact that high dietary MUFA and SFA can reduce the catabolism of n-3 LC-PUFA (Turchini et al., 2011a). Another interesting result in the present study was that the ratio of DHA to EPA was much higher in polar and neutral lipids than in the feeds, which suggested that pompano actively converted EPA to DHA. Our previous studies have shown that pompano has the capability to convert EPA to DHA, despite the lack of a complete pathway for the biosynthesis of LC-PUFA (Wang et al., 2020; Zhang et al., 2019). Similar results were reported in tilapia, where fish fed fish oil-free diets maintained high DHA/EPA ratios in both polar and neutral lipid (Liu et al., 2019).

In the present trial, the PNO diet with high dietary LNA, increased whole body lipid content, but decreased liver lipid content in pompano. Consistent with this, previous studies reported that feeding peanut oil (as in the PNO diet) increased muscle lipid and reduced liver lipid contents in freshwater fish including rainbow trout (Acar and Türker, 2018) and goldfish Carassius auratus gibelio (Wang et al., 2010). Another previous study showed that high dietary LNA significantly increased the expression of ppard in Wuchang bream Megalobrama amblycephala (Li et al., 2015). The present study showed that the highest levels of ppara and cpt1 mRNA were found in fish fed the PNO diet with highest LNA. Both ppara and cpt 1 are genes with important roles in the regulation of $\beta$-oxidation and, thus, in the process of fatty acid catabolism (Stubhaug et al., 2005ab; Kersten et al., 2000), suggesting that the high dietary LNA content could promote fatty acid catabolism, thereby reducing lipid content in the liver of fish fed diet PNO. Furthermore, the mRNA level of apoB100 was also higher in fish fed the PNO diet. $A p o B 100$ is an indispensable component of very low-density lipoprotein (VLDL) (Pan et al., 2008), and LNA was reported to significantly increase apoB100 secretion in mammalian liver cells (López-Soldado et al., 2009). As VLDL is the main route for lipid export from the liver, increased apoB100 expression can also help reduce the lipid content in liver.

The ratio of ALA to LNA is another factor that may affect tissue lipid deposition. In the present study, other than diets LO and PFO, the content of ALA was low in the 
VO diets, but the level of ALA in pompano tissues was higher than the levels in these diets. In contrast, the levels of ALA deposited in the tissues of pompano fed the LO and PFO diets was lower than the levels in the diets. Indeed, the total lipid content of pompano appeared most closely to be related to the ALA to LNA ratio. The rank order for this ratio in the $\mathrm{VO}$ feeds was $\mathrm{PFO}>\mathrm{LO}>\mathrm{CO}>\mathrm{OO}=\mathrm{CNO}>\mathrm{OTO}>\mathrm{PO}>\mathrm{PNO}$, while the rank order for whole body lipid content was $\mathrm{PNO}>\mathrm{OTO}>\mathrm{CO}>\mathrm{OO}>\mathrm{CNO}>$ $\mathrm{PO}>\mathrm{LO}>\mathrm{PFO}$. Therefore, the diets with the highest ALA/LNA ratio (PFO and LO) resulted in the lowest body lipid contents while the diet with the lowest ALA/LNA ratio PNO) gave the highest body lipid content. This association between body lipid content and dietary ALA/LNA ratio was stronger than the associations between body lipid content and the individual fatty acids, ALA and LNA. The rank order for ALA in the feeds was $\mathrm{PFO}>\mathrm{LO}>\mathrm{CNO}>\mathrm{OTO}=\mathrm{PNO}>\mathrm{PO}>\mathrm{OO}>\mathrm{CO}$, and for LNA it was $\mathrm{PNO}>\mathrm{LO}>\mathrm{CNO}>\mathrm{PO}>\mathrm{PFO}>\mathrm{OTO}>\mathrm{OO}>\mathrm{CO}$. Similarly, total SAFA and MUFA in feeds did not show as strong an association as ALA/LNA ratio with whole body lipid content.

In conclusion, of the $\mathrm{VO}$ tested, fish fed the $\mathrm{CO}$ diet showed the best growth performance and better antioxidant capability of juvenile golden pompano T. ovatus. The excessive accumulation of lipid in fish caused by dietary VO may be related to the balance of dietary fatty acids, especially the ALA/LNA ratio. When the diet lacks essential fatty acid, such as DHA, the fish may retain more lipid in order to maintain the level of this fatty acid. Dietary peanut oil significantly increased the expression of genes related to fatty acid catabolism and transport, which may be related to the high content of LNA. In summary, the present study confirmed the effects of various lipid sources of VO on the growth performance, antioxidant capability and lipid deposition in T. ovatus. Furthermore, the results provided the basis for further studies on the underpinning molecular mechanisms, as well as key information for developing precise feeds with balanced dietary fatty acid compositions that will be particularly beneficial for marine species to promote the production of healthy farmed fish. 


\section{Acknowledgments}

This work was financially supported by the China Agriculture Research System (CARS-47), Guangdong MEPP Fund (GDOE No. 2019A30), National Key R\&D Program of China (2018YFD0900400), Guangdong Agriculture Research System (2019KJ150), Natural Science Foundation of Guangdong Province (2018A030313910), and Key Special Project for Introduced Talents Team of Southern Marine Science and Engineering Guangdong Laboratory (Guangzhou) (GML2019ZD0606). 


\section{References}

Aas, T.S., Ytrestøyl, T., Åsgård, T., 2019. Utilization of feed resources in the production of Atlantic salmon (Salmo salar) in Norway: An update for 2016. Aquacult. Rep. $15,100216$.

Acar, Ü., Türker, A., 2018. Response of rainbow trout (Oncorhynchus mykiss) to unrefined peanut oil diets: Effect on growth performance, fish health and fillet fatty acid composition. Aquacult. Nutr. 24, 292-299.

AOAC, 2006. Official Methods of Analysis, 18th ed. Association of Official Analytical Chemists. Arlington: VA

Belaunzaran, X., Lavín, P., Mantecón, A.R., Kramer, J.K.G., Aldai, N., 2017. Effect of slaughter age and feeding system on the neutral and polar lipid composition of horse meat. Internat. J. Anim. Biosci. 12, 417-425.

Bell, J.G., Henderson, R.J., Tocher, D.R., Sargent, J.R., 2004. Replacement of fish oil with increasing levels of linseed oil: Modification of flesh fatty acid composition in Atlantic salmon (Salmo salar) using a fish oil finishing diet. Lipids 39, 223-232.

Bell, J.G., McEvoy, J., Tocher, D.R., McGhee, F., Campbell, P.J., Sargent, J.R., 2001. Replacement of fish oil with rapeseed oil in diets of Atlantic salmon (Salmo salar) affects tissue lipid compositions and hepatocyte fatty acid metabolism. J. Nutr. $131,1535-1543$.

Bell, J.G., Tocher, D.R., Henderson, R.J., Dick, J.R., Crampton, V.O., 2003. Altered fatty acid compositions in Atlantic salmon (Salmo salar) fed diets containing linseed and rapeseed oils can be partially restored by a subsequent fish oil finishing diet. J. Nutr. 133, 2793-2801.

Cruz-Garcia, L., Joan, S., Bouraoui, L., Alfonso, S.V., Jaume, P.S., Joaquim, G., Isabel, N., 2011. Changes in adipocyte cell size, gene expression of lipid metabolism markers, and lipolytic responses induced by dietary fish oil replacement in gilthead sea bream (Sparus aurata L.). Comp. Biochem. Physiol. A. Mol. Integr. Physiol. $158,391-399$. 
Demir, O., Türker, A., Acar, Ü., Kesbiç, O.S., 2014. Effects of dietary fish oil replacement by unrefined peanut oil on the growth, serum biochemical and hematological parameters of Mozambique tilapia juveniles (Oreochromis mossambicus). Turkish J. Fish. Aquat. Sci. 14, 887-892.

Dos Santos, H.M.C., Nishiyama, M.F., Bonafe, E.G., De Oliveira, C.A.L., Matsushita, M., Visentainer, J.V., Ribeiro, R.P., 2014. Influence of a Diet Enriched with Perilla Seed Bran on the Composition of Omega-3 Fatty Acid in Nile Tilapia. J. Am. Oil. Chem. Soc. 91(11), 1939-1948.

Du, Z., Clouet, P., Huang, L., Degrace, P., Zheng, W., He, J., Tian, L., Liu, Y., 2008. Utilization of different dietary lipid sources at high level in herbivorous grass carp (Ctenopharyngodon Idella) fed high-fat diets. Br. J. Nutr. 95, 905-915.

Firat, O., Makay, O., Yeniay, L., Gokce, G., Yenisey, C., Coker, A., 2017. Omega-3 fatty acids inhibit oxidative stress in a rat model of liver regeneration. Ann. Surg. Treat. Res. 93, 1-10.

Folch, J., Lees, M., Sloane Stanley, G.H., 1957. A simple method for the isolation and purification of total lipids from animal tissues. J. Biol. Chem. 226, 497-509.

Fountoulaki, E., Vasilaki, A., Hurtado, R., Grigorakis, K., Karacostas, I., Nengas, I., Rigos, G., Kotzamanis Y., Venou, B., Alexis, M.N., 2009. Fish oil substitution by vegetable oils in commercial diets for gilthead sea bream (Sparus aurata L.); effects on growth performance, flesh quality and fillet fatty acid profile: Recovery of fatty acid profiles by a fish oil finishing diet fluctuating water temperature. Aquaculture 289, 317-326.

Han, C., Wen, X, Zheng, Q., Li, H., 2012. Effects of dietary lipid levels on lipid deposition and activities of lipid metabolic enzymes in hybrid tilapia (Oreochromis niloticus $\times$ O. aureus). J. Anim. Physiol. Anim. Nutr. 95, 609-615.

Henderson, R.J., 1996. Fatty acid metabolism in freshwater fish with particular reference to polyunsaturated fatty acids. Archiv für Tierernaehrung 49, 5-22.

Huang, H., Mai, W., Liu, D., Hao, Y., Tao, J., Dong, Y., 2008. The oxidation ratio of LDL: a predictor for coronary artery disease. Dis. Markers 24, 341-349.

Jordal, A.E.O., Lie, Ø., Torstensen, B.E., 2007. Complete replacement of dietary fish 
oil with a vegetable oil blend affect liver lipid and plasma lipoprotein levels in Atlantic salmon (Salmo salar L.). Aquacult. Nutr. 1, 114-130.

Kapilan, S., 2008. Variation of phenolic content in coconut oil extracted by two conventional methods. Internat. J. Food Sci. Technol. 43, 597-602.

Kersten, S., Desvergne, B., Wahli, W., 2000. Roles of PPARs in health and disease. Nature 405, 421-424.

Li, Y., Monroig, Ó., Zhang, L., Wang, S., Zheng, X., Dick, J.R., You, C., Tocher, D.R., 2010. Vertebrate fatty acyl desaturase with $\Delta 4$ activity. Proc. Natl. Acad. Sci. USA $107,16840-16845$.

Li, Y., Zhao, Y. T., Zhang, Y. K., Liang, X., Zhang, Y., Gao, J., 2015. Growth performance, fatty acid composition, peroxisome proliferator-activated receptors gene expressions, and antioxidant abilities of blunt snout bream, Megalobrama amblycephala, fingerlings fed different dietary oil sources. J. World Aquacult. Soc. 46, 395-408.

Li, M., Zhang, M., Ma, Y., Ye, R., Wang, M., Chen, H., Xie, D., Dong, Y., Ning, L., You, C., Wang, S., Li, Y., 2020a. Dietary supplementation with n-3 high unsaturated fatty acids decreases serum lipid levels and improves flesh quality in the marine teleost golden pompano Trachinotus ovatus. Aquaculture. 516.

Li, M., Xu, C., Ma, Y., Ye, R., Chen, H., Xie, D., Zhang, G., Zhang, M., Wang, M., You, C., Wang, S., Ning, L., Luo, M., Li, Y., 2020b. Effects of dietary n-3 highly unsaturated fatty acids levels on growth, lipid metabolism and innate immunity in juvenile golden pompano (Trachinotus ovatus). Fish \& Shellfish Immunology. 105, 177-185.

Li, X., Liu, B., Liu, B., Zhang, N., Guo, L., Zhu, K., Guo, H., Jiang, S., Zhang, D., 2019. Growth performance, lipid deposition and serum biochemistry in golden pompano Trachinotus Ovatus (Linnaeus, 1758) fed diets with various fish oil substitutes. Soc. Israeli Aquacult. Mar. Biotechnol. 71, 1589-1600.

Liu, K., Liu, H., Chi, S., Dong, X., Yang, Q., Tan, B., 2018. Effects of different dietary lipid sources on growth performance, body composition and lipid metabolismrelated enzymes and genes of juvenile golden pompano, Trachinotus ovatus. 
Aquacult. Res. 49, 717-725.

Liu, Y., Jiao, J., Gao, S., Ning, L., Limbu, S., Qiao, F., Chen, L, Zhang, M., Du, Z., 2019. Dietary oils modify lipid molecules and nutritional value of fillet in Nile tilapia: A deep lipidomics analysis. Food Chem. 277, 515-523.

López-Soldado, I., Avella, M., Botham, K. M., 2009. Differential influence of different dietary fatty acids on very low-density lipoprotein secretion when delivered to hepatocytes in chylomicron remnants. Metabolism 58, 186-195.

Lu, Y., Jin, M., Yuan, Y., Xiong, J., Ma, H., Zhou, Q., 2018. Effects of different lipid sources on growth performance, body composition, the serum biochemical indices, fatty acids composition and antioxidant capacity in juvenile yellow catfish (Pelteobagrus fulvidraco). J. Fisheries China 042, 1094-1110.

Luo, L., Xue, M., Vachot, C., Geurden, I., Kaushik, S., 2014. Dietary medium chain fatty acids from coconut oil have little effects on postprandial plasma metabolite profiles in rainbow trout (Oncorhynchus mykiss). Aquaculture 420-421, 24-31.

Ma, X., Wang, F., Han, H., Wang, Y., Lin, Y., 2014. Replacement of dietary fish meal with poultry by-product meal and soybean meal for golden pompano, Trachinotus ovatus, reared in net pens. J. World Aquacult. Soc. 45, 662-671.

Martínez-Lorens, S., Vidal, A.T., Moñino, A.V., Torres, M.P., Jover-Cerdá, M., 2007. Effects of dietary soybean oil concentration on growth, nutrient utilization and muscle fatty acid composition of gilthead bream (Sparus aurata L.). Aquacult. Res. 38, 76-81.

Menoyo, D., Izquierdo, M.S., Robaina, L., Ginés, R., Lopez-Bote, C.J., Bautista, J. M., 2004. Adaptation of lipid metabolism, tissue composition and flesh quality in gilthead sea bream (Sparus aurata) to the replacement of dietary fish oil by linseed and soybean oils. Br. J. Nutr. 92, 41-52.

Monroig, Ó., Tocher, D.R., Castro, L.F.C., 2018. Polyunsaturated fatty acid biosynthesis and metabolism in fish. In: Burdge, G.C. (Ed.), Polyunsaturated Fatty Acid Metabolism, Academic Press and AOCS Press, London, pp. 31-60.

Mourente, G., Good, J.E., Bell, J.G., 2005. Partial substitution of fish oil with rapeseed, linseed and olive oils in diets for European sea bass (Dicentrarchus labrax L.): 
effects on flesh fatty acid composition, plasma prostaglandins $\mathrm{E}_{2}$ and $\mathrm{F}_{2}$, immune function and effectiveness of a fish oil finishing diet. Aquacult. Nutr. 11, 25-40.

Naing, O.A., Satoh, S., Tsuchida, N., 2007. Effect of replacements of fishmeal and fish oil on growth and dioxin contents of rainbow trout. Fisheries Sci. 7, 750-759.

Nanton, D.A., Vegusdal, A., Rørå, A.M.B., Ruyter, B., Baeverfjord, G., Torstensen, B.E., 2007. Muscle lipid storage pattern, composition, and adipocyte distribution in different parts of Atlantic salmon (Salmo salar) fed fish oil and vegetable oil. Aquaculture 265, 230-243.

Nevin, K.G., Rajamohan, T., 2004. Beneficial effects of virgin coconut oil on lipid parameters and in vitro LDL oxidation. Clin. Biochem. 37, 830-835.

Nevin, K.G., Rajamohan, T., 2009. Wet and dry extraction of coconut oil: impact on lipid metabolic and antioxidant status in cholesterol coadministered rats. Can. J. Physiol. Pharmacol. 87, 610-616.

Olsen, R.E., Hansen, A.C., Rosenlund, G., Hemre, G.-I., Mayhew, T.M., Knudsen D.L., Eroldoğan O.T., Myklebust, R., Karlseng, Ø., 2007. Total replacement of fish meal with plant proteins in diets for Atlantic cod (Gadus morhua L.) II - Health aspects. Aquaculture 272, 612-624.

Osman, S.K., Ümit Acar, Y.M., Bulut, M., Nejdet, G., Yilmaz, S., 2016. Unrefined peanut oil as a lipid source in diets for juveniles of two-banded seabream diplodus vulgaris. N. AM. J. Aquacult. 78, 64-71.

Pan, M., Maitin, V., Parathath, S., Andreo, U., Lin, S., St. Germain, C., Yao, Z., Maxfield, F.R., Williams, K.J., Fisher, E.A., 2008. Presecretory oxidation, aggregation, and autophagic destruction of apoprotein-B: a pathway for late-stage quality control. Proc. Natl. Acad. Sci. USA 105, 5862-5867.

Peng, S., Chen, L., Qin, J., Hou, J., Yu, N., Long, Z., Ye, J., Sun, X., 2008. Effects of replacement of dietary fish oil by soybean oil on growth performance and liver biochemical composition in juvenile black seabream, Acanthopagrus schlegeli. Aquaculture 276, 154-161.

Pettersson, A., Johnsson, L., Brannas, E., Pickova, J., 2010. Effects of rapeseed oil replacement in fish feed on lipid composition and self-selection by rainbow trout 
(Oncorhynchus mykiss). Aquacult. Nutr. 15, 577-586.

Preedy, R.V., Watson, R.R., Vinood, P., 2011. Use of tea (Camellia oleifera Abel.) seeds in human health. In: Preedy, R.V., Watson, R.R., (Eds.), Nuts and Seeds in Health and Disease Prevention. Academic Press, Elsevier. Ch. 132, Pp.1173-1185.

Rodrigo, J.V., Silvia, M.G.S., Alexandre, M.K., Baggio, S.R., 2008. Replacement of fish oil with vegetable oils in diets for jundiá (Rhamdia quelen Quoy and Gaimard 1824): effects on performance and whole body fatty acid composition. Aquacult. Res. 39, 657-665.

Seno, O.A., Takakuwa, F., Hashiguchi, T., Morioka, K., Masumoto, T., Fukada, H., 2008. Replacement of dietary fish oil with olive oil in young yellowtail Seriola quinqueradiata: effects on growth, muscular fatty acid composition and prevention of dark muscle discoloration during refrigerated storage. Fisheries Sci. 74, 1297-1306.

Sprague, M., Betancor, M.B., Tocher, D.R., 2017. Microbial and genetically engineered oils as replacements for fish oil in aquaculture feeds. Biotechnol. Lett. 39, 15991609.

Stubhaug, I., Froyland, L., Torstensen, B.E., 2005a. $\beta$-Oxidation capacity of red and white muscle and liver in Atlantic salmon (Salmo salar L.): effects of increasing dietary rapeseed oil and olive oil to replace capelin oil. Lipids 40, 39-47.

Stubhaug, I., Tocher, D.R., Bell, J.G., Dick, J.R., Torstensen, B.E., 2005b. Fatty acid metabolism in Atlantic salmon (Salmo salar L.) hepatocytes and influence of dietary vegetable oil. Biochim. Biophys. Acta 1734, 277-288.

Sun, S., Ye, J., Chen, J., Wang, Y., Chen, L., 2011. Effect of dietary fish oil replacement by rapeseed oil on the growth, fatty acid composition and serum non-specific immunity response of fingerling black carp, Mylopharyngodon piceus. Aquacult. Nutr. 17, 441-450.

Sun, X., Guo, H., Zhu, K., Zhang, N., Yu, W., Wu, N., Jiang, S., Zhang, D., 2018. Feed type regulates the fatty acid profiles of golden pompano Trachinotus ovatus (Linnaeus 1758). J. Appl. Anim. Res. 1-4, 60-63.

Tan, X., Sun, Z., Huang, Z., Zhou, C., Lin, H., Tan, L., Xun, P., Huang, Q., 2017. Effects 
of dietary hawthorn extract on growth performance, immune responses, growthand immune-related genes expression of juvenile golden pompano (Trachinotus ovatus) and its susceptibility to Vibrio harveyi infection. Fish Shellfish Immunol. $70,656-664$.

Tang, Y., Zhang, J., Ai, C., Hu, B., 2013. Review of nutrient requirements and formula dietary for Trachinotus ovatus. Feed Indust. 34, 46-50.

Tocher, D.R., 2015. Omega-3 long-chain polyunsaturated fatty acids and aquaculture in perspective. Aquaculture 449, 94-107.

Torstensen, B.E., Espe, M., Stubhaug, I., Lie, Ø., 2011. Dietary plant proteins and vegetable oil blends increase adiposity and plasma lipids in Atlantic salmon (Salmo salar L.). Br. J. Nutr. 106, 633-647.

Torstensen, B.E., Frøyland, L., Ørnsrud, R., Lie, Ø., 2004. Tailoring of a cardioprotective muscle fatty acid composition of Atlantic salmon (Salmo salar) fed vegetable oils. Food Chem. 87, 567-580.

Turchini, G.M., Torstensen, B.E., Ng, W-K., 2009. Fish oil replacement in finfish nutrition. Rev. Aquacult. 1, 10-57.

Turchini, G.M., Francis, D.S., Senadheera, S. P. S. D., Thanuthong, T., De Silva, S.S., 2011a. Fish oil replacement with different vegetable oils in Murray cod: Evidence of an "omega-3 sparing effect" by other dietary fatty acids. Aquaculture 315, 250259.

Turchini, G.M., Ng, W.-K. Tocher, D.R. (Eds.), 2011b. Fish Oil Replacement and Alternative Lipid Sources in Aquaculture Feeds. Taylor \& Francis, CRC Press, Boca Raton. p.533.

Tutman, P., Glavic, N., Kozol, V., Skaramuca, B., Glamuzina, B., 2004. Preliminary information on feeding and growth of pompano, Trachinotus ovatus (Linnaeus, 1758) (Pisces; Carangidae) in captivity. Aquacult. Internat. 12, 387-393.

Wang, F., Han, H., Wang, Y., Ma, X., 2013. Growth, feed utilization and body composition of juvenile golden pompano Trachinotus ovatus fed at different dietary protein and lipid levels. Aquacult. Nutr. 19, 360-367.

Wang, Y.H., Wang, A.M., Liu, W.B., You, Y.B., Han, G.M., Zang, Y., 2010. Effects of 
dietary oil sources on growth performance, apparent digestibility and body composition of Carassius auratus gibelio. Journal of Fisheries of China 34(9), 1440-1446.

Wang, S., Wang, M., Zhang, H., Yan, X., Guo, H., You, C., Tocher, D.R., Chen, C., Li, Y., 2020. Long-chain polyunsaturated fatty acid metabolism in carnivorous marine teleosts: Insight into the profile of endogenous biosynthesis in golden pompano Trachinotus ovatus. Aquacult. Res. 51, 623-635.

Wijekoon, M.P.A., Parrish, C.C., Mansour, A., 2014. Effect of dietary substitution of fish oil with flaxseed or sunflower oil on muscle fatty acid composition in juvenile steelhead trout (Oncorhynchus mykiss) reared at varying temperatures. Aquaculture 433:74-81.

Xu, H., Zhang, Y., Wang, J., Zuo, R., Mai, K., Ai, Q., 2015. Replacement of fish oil with linseed oil or soybean oil in feeds for japanese seabass, lateolabrax japonicus: effects on growth performance, immune response, and tissue fatty acid composition. J. World Aquacult. Soc. 46, 349-362.

Ytrestøyl, T., Aas, T. S., Åsgård, T., 2015. Utilisation of feed resources in production of Atlantic salmon (Salmo salar) in Norway. Aquaculture 448, 365-374.

Zaid, A.A., Akinremi, O.A., 2009. Dietary effects of coconut oil and peanut oil in improving biochemical characteristics of Clarias gariepinus juvenile. Turkish J. Fish. Aquat. Sci. 9, 105-110.

Zhang, M., Chen, C.Y., You, C.H., Chen, B.J., Wang, S.Q., Li, Y.Y., 2019. Effects of different dietary ratios of docosahexaenoic to eicosapentaenoic acid (DHA/EPA) on the growth, non-specific immune indices, tissue fatty acid compositions and expression of genes related to LC-PUFA biosynthesis in juvenile golden pompano Trachinotus ovatus. Aquaculture. 505, 488-495.

Zhou, C., Ge, X., Lin, H., Huang, Z., Tan, X., 2015. Effect of dietary carbohydrate levels on growth performance, body composition, intestinal and hepatic enzyme activities, and growth hormone gene expression of juvenile golden pompano, Trachinotus ovatus. Aquaculture 437, 390-397. 
Table 1. Ingredients (\%), proximate compositions and fatty acid composition ( $\%$ total fatty acids) of experimental diets (\% dry matter).

\begin{tabular}{|c|c|c|c|c|c|c|c|c|c|}
\hline Ingredients (\%) & FO & $\mathrm{CO}$ & $\mathrm{PO}$ & OTO & $\mathrm{OO}$ & $\mathrm{CNO}$ & $\mathrm{PNO}$ & LO & PFO \\
\hline Fish oil & 7.00 & 0.00 & 0.00 & 0.00 & 0.00 & 0.00 & 0.00 & 0.00 & 0.00 \\
\hline Coconut oil & 0.00 & 7.00 & 0.00 & 0.00 & 0.00 & 0.00 & 0.00 & 0.00 & 0.00 \\
\hline Palm oil & 0.00 & 0.00 & 7.00 & 0.00 & 0.00 & 0.00 & 0.00 & 0.00 & 0.00 \\
\hline Oil-tea oil & 0.00 & 0.00 & 0.00 & 7.00 & 0.00 & 0.00 & 0.00 & 0.00 & 0.00 \\
\hline Olive oil & 0.00 & 0.00 & 0.00 & 0.00 & 7.00 & 0.00 & 0.00 & 0.00 & 0.00 \\
\hline Canola oil & 0.00 & 0.00 & 0.00 & 0.00 & 0.00 & 7.00 & 0.00 & 0.00 & 0.00 \\
\hline Peanut oil & 0.00 & 0.00 & 0.00 & 0.00 & 0.00 & 0.00 & 7.00 & 0.00 & 0.00 \\
\hline Linseed oil & 0.00 & 0.00 & 0.00 & 0.00 & 0.00 & 0.00 & 0.00 & 7.00 & 0.00 \\
\hline Perilla seed oil & 0.00 & 0.00 & 0.00 & 0.00 & 0.00 & 0.00 & 0.00 & 0.00 & 7.00 \\
\hline Others $^{1}$ & 93.00 & 93.00 & 93.00 & 93.00 & 93.00 & 93.00 & 93.00 & 93.00 & 93.00 \\
\hline \multicolumn{10}{|c|}{ Proximate composition (\% dry weight) } \\
\hline Moisture & 9.44 & 9.75 & 9.75 & 9.44 & 11.17 & 12.95 & 11.62 & 10.64 & 9.76 \\
\hline Crude protein & 45.48 & 46.04 & 45.62 & 46.54 & 45.47 & 45.37 & 45.31 & 45.43 & 46.17 \\
\hline Crude lipid & 12.57 & 12.54 & 12.86 & 12.49 & 11.96 & 12.60 & 12.12 & 12.39 & 12.56 \\
\hline Ash & 8.49 & 8.91 & 9.11 & 8.52 & 8.67 & 8.73 & 8.75 & 8.60 & 8.64 \\
\hline \multicolumn{10}{|c|}{ Fatty acid composition ( $\%$ total fatty acids) } \\
\hline C10:0 & 0.00 & 3.26 & 0.00 & 0.00 & 0.00 & 0.00 & 0.00 & 0.00 & 0.00 \\
\hline $\mathrm{C} 12: 0$ & 0.00 & 33.79 & 1.70 & 0.06 & 0.00 & 0.00 & 0.00 & 0.00 & 0.00 \\
\hline C14:0 & 5.78 & 13.99 & 3.12 & 1.65 & 1.24 & 1.29 & 1.66 & 1.35 & 1.51 \\
\hline C16:0 & 19.88 & 11.61 & 32.03 & 13.13 & 14.72 & 10.32 & 12.95 & 10.32 & 9.40 \\
\hline C16:1n-9 & 5.62 & 1.48 & 1.67 & 1.64 & 1.47 & 1.36 & 1.47 & 1.32 & 1.34 \\
\hline C18:0 & 3.74 & 3.08 & 2.59 & 2.01 & 3.47 & 3.08 & 2.72 & 3.54 & 1.81 \\
\hline C18:1n-9 & 12.31 & 9.16 & 29.90 & 54.61 & 59.68 & 41.64 & 32.52 & 17.48 & 15.41 \\
\hline C18:2n-6 & 11.22 & 10.35 & 17.56 & 16.77 & 10.98 & 20.63 & 38.50 & 19.83 & 17.10 \\
\hline $\mathrm{C} 20: 0$ & 0.45 & 0.11 & 0.12 & 0.11 & 0.16 & 0.36 & 0.13 & 0.09 & 0.14 \\
\hline C20:1n-9 & 0.13 & 0.06 & 0.06 & 0.07 & 0.06 & 0.08 & 0.21 & 0.07 & 0.08 \\
\hline C18:3n-3 & 5.21 & 1.33 & 1.57 & 1.70 & 1.40 & 8.99 & 1.70 & 37.68 & 45.99 \\
\hline$C 20: 2 n-6$ & 2.11 & 0.61 & 0.42 & 0.57 & 0.29 & 0.43 & 0.54 & 0.40 & 0.54 \\
\hline$C 22: 1 n-9$ & 0.00 & 0.00 & 0.00 & 0.00 & 0.00 & 5.21 & 0.00 & 0.00 & 0.00 \\
\hline$C 20: 4 n-6$ & 1.48 & 0.26 & 0.43 & 0.24 & 0.22 & 0.16 & 0.12 & 0.26 & 0.19 \\
\hline$C 20: 4 n-3$ & 0.42 & 0.11 & 0.07 & 0.09 & 0.03 & 0.07 & 0.14 & 0.09 & 0.07 \\
\hline$C 20: 5 n-3$ & 8.83 & 2.96 & 3.53 & 3.68 & 2.61 & 2.73 & 2.30 & 2.86 & 2.14 \\
\hline$C 22: 5 n-3$ & 0.67 & 0.18 & 0.27 & 0.19 & 0.15 & 0.15 & 0.12 & 0.18 & 0.22 \\
\hline$C 22: 6 n-3$ & 10.34 & 2.82 & 2.27 & 2.26 & 2.17 & 2.51 & 2.38 & 2.83 & 1.94 \\
\hline$\Sigma \mathrm{SFA}^{2}$ & 29.85 & 69.46 & 39.56 & 16.97 & 19.59 & 15.05 & 17.46 & 15.30 & 12.86 \\
\hline$\Sigma \mathrm{MUFA}^{3}$ & 18.87 & 10.96 & 31.94 & 56.68 & 61.37 & 48.50 & 34.49 & 19.09 & 17.12 \\
\hline$\Sigma \mathrm{PUFA}^{4}$ & 42.58 & 18.84 & 26.43 & 25.77 & 17.95 & 35.81 & 46.00 & 64.34 & 68.45 \\
\hline$\Sigma$ n-6 PUFA ${ }^{5}$ & 15.42 & 11.45 & 18.71 & 17.85 & 11.59 & 21.36 & 39.36 & 20.69 & 18.09 \\
\hline$\Sigma$ n-3 PUFA ${ }^{6}$ & 27.15 & 7.40 & 7.72 & 7.92 & 6.36 & 14.45 & 6.63 & 43.65 & 50.36 \\
\hline$\Sigma$ LC-PUFA $^{7}$ & 25.68 & 6.95 & 6.99 & 7.03 & 5.51 & 6.05 & 5.59 & 6.63 & 5.10 \\
\hline
\end{tabular}


\begin{tabular}{cccccccccc} 
n-3 / n-6 PUFA & 1.76 & 0.65 & 0.41 & 0.44 & 0.55 & 0.68 & 0.17 & 2.11 & 2.78 \\
\hline${ }^{1}$ Others: included $25 \%$ fishmeal $(72.7 \%$ crude protein, $8.9 \%$ total lipid, $1.5 \%$ & $20: 4 n-6,14.9 \%$
\end{tabular} 20:5n-3, $15.8 \%$ 22:6n-3), $12 \%$ fermented soybean meal (54.8\% crude protein, $2.0 \%$ total lipid), $28 \%$ soya concentrate (70.9 \% crude protein), $2 \%$ vitamin and $2 \%$ mineral premixes (obtained from Yuequn Ocean Biological Research Development Co. Ltd., Jieyang, Guangdong, China), $5 \%$ $\alpha$-Starch, $12 \%$ Cassava starch, $2 \%$ Soybean lecithin, $0.8 \% \mathrm{Ca}\left(\mathrm{H}_{2} \mathrm{PO}_{4}\right), 0.2 \%$ Lutein, $0.5 \%$ Choline chloride, $0.5 \%$ Betaine and $3 \%$ Microcrystalline cellulose; ${ }^{2} \Sigma \mathrm{SFA}$ is the sum of saturated fatty acids; ${ }^{3}$ EMUFA is the sum of monounsaturated fatty acids; ${ }^{4}$ $\Sigma$ PUFA is the sum of polyunsaturated fatty acids (PUFA); ${ }^{5} \Sigma \mathrm{n}-6$ PUFA is the sum of n-6 polyunsaturated fatty acids; ${ }^{6}$ $\Sigma \mathrm{n}-3$ PUFA is the sum of n-3 polyunsaturated fatty acids; ${ }^{7} \Sigma$ LC-PUFA is the sum of long-chain polyunsaturated fatty acids.

FO, fish oil; CO, coconut oil; PO, palm oil; OTO, camellia oil; OO, olive oil; CNO, canola oil; PNO, peanut oil; LO, linseed oil; PFO, perilla oil. 
Table 2. Growth performance, feed efficiency, and biometrical parameters of juvenile pompano T. ovatus fed the experimental diets for 8 weeks.

\begin{tabular}{|c|c|c|c|c|c|c|c|c|c|}
\hline \multirow[t]{2}{*}{ Parameter } & \multicolumn{9}{|l|}{ Dietary treatment } \\
\hline & $\mathrm{FO}$ & $\mathrm{CO}$ & $\mathrm{PO}$ & OTO & $\mathrm{OO}$ & $\mathrm{CNO}$ & PNO & LO & $\mathrm{PFO}$ \\
\hline Initial weight (g) & $10.69 \pm 0.15$ & $10.60 \pm 0.13$ & $10.56 \pm 0.13$ & $10.61 \pm 0.11$ & $10.59 \pm 0.09$ & $10.59 \pm 0.08$ & $10.64 \pm 0.13$ & $10.55 \pm 0.09$ & $10.49 \pm 0.08$ \\
\hline Final weight (g) & $45.51 \pm 1.11^{\mathrm{ab}}$ & $49.65 \pm 3.01^{\mathrm{b}}$ & $39.42 \pm 1.88^{\mathrm{a}}$ & $45.00 \pm 2.72^{\mathrm{ab}}$ & $41.58 \pm 1.08^{\mathrm{ab}}$ & $42.44 \pm 1.17^{\mathrm{ab}}$ & $42.37 \pm 0.67^{\mathrm{ab}}$ & $40.78 \pm 2.17^{\mathrm{ab}}$ & $49.68 \pm 1.60^{b}$ \\
\hline $\operatorname{SR}(\%)^{1}$ & $86.67 \pm 3.85$ & $84.44 \pm 1.11$ & $83.33 \pm 3.33$ & $87.78 \pm 1.11$ & $81.11 \pm 9.87$ & $91.11 \pm 2.93$ & $88.89 \pm 1.11$ & $94.44 \pm 2.93$ & $93.33 \pm 5.09$ \\
\hline WG $(\%)^{2}$ & $325.72 \pm 6.61^{\mathrm{ab}}$ & $368.49 \pm 29.31^{b}$ & $272.97 \pm 14.31^{\mathrm{a}}$ & $323.90 \pm 23.28^{\mathrm{ab}}$ & $292.83 \pm 13.03^{\mathrm{ab}}$ & $300.47 \pm 8.48^{\mathrm{ab}}$ & $298.29 \pm 11.16^{\mathrm{ab}}$ & $286.98 \pm 23.50^{\mathrm{ab}}$ & $373.78 \pm 15.01^{\mathrm{b}}$ \\
\hline $\operatorname{SGR}(\% / \text { day })^{3}$ & $2.59 \pm 0.03^{\mathrm{ab}}$ & $2.75 \pm 0.11^{\mathrm{b}}$ & $2.35 \pm 0.07^{\mathrm{a}}$ & $2.57 \pm 0.10^{\mathrm{ab}}$ & $2.44 \pm 0.06^{\mathrm{ab}}$ & $2.48 \pm 0.04^{\mathrm{ab}}$ & $2.47 \pm 0.05^{\mathrm{ab}}$ & $2.41 \pm 0.11^{\mathrm{ab}}$ & $2.78 \pm 0.06^{\mathrm{b}}$ \\
\hline $\mathrm{FCR}^{4}$ & $1.74 \pm 0.05$ & $1.54 \pm 0.12$ & $2.05 \pm 0.12$ & $1.77 \pm 0.15$ & $1.89 \pm 0.07$ & $1.81 \pm 0.06$ & $1.84 \pm 0.05$ & $2.03 \pm 0.16$ & $1.58 \pm 0.06$ \\
\hline VSI $(\%)^{5}$ & $6.84 \pm 0.36^{\mathrm{a}}$ & $9.16 \pm 0.43^{b}$ & $8.84 \pm 0.62^{\mathrm{ab}}$ & $8.90 \pm 0.51^{\mathrm{ab}}$ & $8.58 \pm 0.47^{\mathrm{ab}}$ & $7.48 \pm 0.49^{\mathrm{ab}}$ & $7.72 \pm 0.38^{\mathrm{ab}}$ & $7.51 \pm 0.57^{\mathrm{ab}}$ & $7.59 \pm 0.02^{\mathrm{ab}}$ \\
\hline $\operatorname{HSI}(\%)^{6}$ & $2.01 \pm 0.11^{\mathrm{a}}$ & $3.02 \pm 0.01^{\mathrm{b}}$ & $3.01 \pm 0.29^{b}$ & $2.91 \pm 0.22^{\mathrm{ab}}$ & $2.82 \pm 0.09^{\mathrm{ab}}$ & $2.49 \pm 0.26^{\mathrm{ab}}$ & $2.42 \pm 0.14^{\mathrm{ab}}$ & $2.63 \pm 0.17^{\mathrm{ab}}$ & $2.19 \pm 0.14^{\mathrm{ab}}$ \\
\hline $\mathrm{CF}(\%)^{7}$ & $3.44 \pm 0.08^{\mathrm{a}}$ & $3.66 \pm 0.08^{\mathrm{ab}}$ & $3.49 \pm 0.03^{\mathrm{ab}}$ & $3.79 \pm 0.07^{\mathrm{b}}$ & $3.53 \pm 0.04^{\mathrm{ab}}$ & $3.64 \pm 0.01^{\mathrm{ab}}$ & $3.58 \pm 0.09^{\mathrm{ab}}$ & $3.63 \pm 0.02^{\mathrm{ab}}$ & $3.63 \pm 0.06^{\mathrm{ab}}$ \\
\hline
\end{tabular}

Values are means $\pm \mathrm{SE}(\mathrm{n}=3)$. Means values in the same row with different superscripts are significantly different $(P<0.05)$.

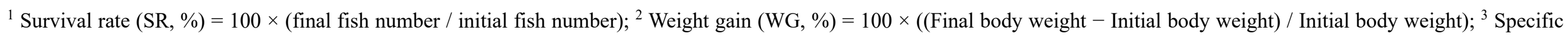

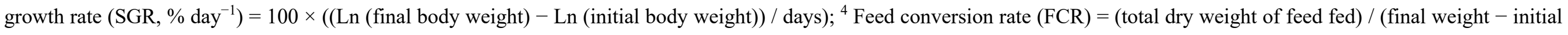

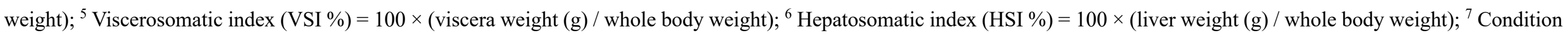
factor $(\mathrm{CF}, \%)=100 \times\left(\right.$ fish weight $(\mathrm{g}) /$ fish length $\left.(\mathrm{cm})^{3}\right)$.

FO, fish oil; CO, coconut oil; PO, palm oil; OTO, camellia oil; OO, olive oil; CNO, canola oil; PNO, peanut oil; LO, linseed oil; PFO, perilla oil. 
Table 3. Whole body composition (\% wet matter basis) of juvenile pompano T. ovatus fed the experimental diets for 8 weeks.

\begin{tabular}{|c|c|c|c|c|c|c|c|c|c|}
\hline \multirow{2}{*}{ Parameter } & \multicolumn{9}{|c|}{ Dietary treatment } \\
\hline & $\mathrm{FO}$ & $\mathrm{CO}$ & $\mathrm{PO}$ & OTO & $\mathrm{OO}$ & $\mathrm{CNO}$ & $\mathrm{PNO}$ & LO & $\mathrm{PFO}$ \\
\hline Moisture & $65.77 \pm 0.50$ & $66.95 \pm 0.79$ & $66.53 \pm 1.73$ & $63.39 \pm 0.92$ & $65.04 \pm 0.76$ & $65.77 \pm 1.01$ & $64.35 \pm 0.23$ & $66.18 \pm 0.28$ & $65.09 \pm 1.38$ \\
\hline Crude protein & $17.12 \pm 0.40^{\mathrm{b}}$ & $16.51 \pm 0.22^{\mathrm{ab}}$ & $15.64 \pm 0.10^{\mathrm{a}}$ & $16.90 \pm 0.07^{\mathrm{b}}$ & $16.76 \pm 0.12^{\mathrm{b}}$ & $16.98 \pm 0.12^{\mathrm{b}}$ & $17.16 \pm 0.32^{b}$ & $17.26 \pm 0.04^{\mathrm{b}}$ & $17.14 \pm 0.04^{\mathrm{b}}$ \\
\hline Total lipid & $15.87 \pm 0.71^{\mathrm{a}}$ & $18.19 \pm 0.33^{\mathrm{bc}}$ & $17.13 \pm 0.50^{\mathrm{abc}}$ & $18.61 \pm 0.24^{\mathrm{c}}$ & $17.59 \pm 0.18^{\mathrm{abc}}$ & $17.44 \pm 0.37^{\mathrm{abc}}$ & $18.62 \pm 0.68^{c}$ & $16.28 \pm 0.41^{\mathrm{ab}}$ & $15.48 \pm 0.63^{\mathrm{a}}$ \\
\hline Ash & $3.61 \pm 0.10^{\mathrm{bc}}$ & $3.13 \pm 0.16^{\mathrm{ab}}$ & $3.64 \pm 0.04^{\mathrm{bc}}$ & $3.19 \pm 0.09^{\mathrm{ab}}$ & $3.56 \pm 0.05^{\mathrm{bc}}$ & $3.92 \pm 0.07^{\mathrm{c}}$ & $3.50 \pm 0.23^{\mathrm{abc}}$ & $2.99 \pm 0.10^{\mathrm{a}}$ & $3.36 \pm 0.05^{\mathrm{abc}}$ \\
\hline
\end{tabular}

Values are mean $\pm \mathrm{SE}(\mathrm{n}=3)$. Means values in the same row with different superscripts are significantly different $(P<0.05)$.

FO, fish oil; CO, coconut oil; PO, palm oil; OTO, camellia oil; OO, olive oil; CNO, canola oil; PNO, peanut oil; LO, linseed oil; PFO, perilla oil. 
Table 4. The serum biochemistry indices of juvenile pompano T. ovatus fed the experimental diets for 8 weeks.

\begin{tabular}{|c|c|c|c|c|c|c|c|c|c|}
\hline \multirow{2}{*}{ ameter } & \multicolumn{9}{|l|}{ Dietary treatment } \\
\hline & $\mathrm{FO}$ & $\mathrm{CO}$ & $\mathrm{PO}$ & OTO & $\mathrm{OO}$ & $\mathrm{CNO}$ & PNO & LO & $\mathrm{PFO}$ \\
\hline $\mathrm{DL}(\mathrm{mmol} / \mathrm{L})^{1}$ & $2.41 \pm 0.04$ & $2.19 \pm 0.15$ & $2.11 \pm 0.23$ & $2.13 \pm 0.09$ & $2.13 \pm 0.01$ & $2.03 \pm 0.07$ & $2.25 \pm 0.05$ & $2.04 \pm 0.12$ & $1.91 \pm 0.17$ \\
\hline $\mathrm{DL}(\mathrm{mmol} / \mathrm{L})^{2}$ & $0.21 \pm 0.01^{\mathrm{a}}$ & $0.30 \pm 0.01^{\mathrm{a}}$ & $0.29 \pm 0.02^{\mathrm{a}}$ & $0.55 \pm 0.03^{b}$ & $0.56 \pm 0.05^{\mathrm{b}}$ & $0.30 \pm 0.03^{\mathrm{a}}$ & $0.22 \pm 0.02^{\mathrm{a}}$ & $0.30 \pm 0.03^{\mathrm{a}}$ & $0.32 \pm 0.02^{\mathrm{a}}$ \\
\hline I $(\mathrm{mmol} / \mathrm{L})^{3}$ & $2.00 \pm 0.19$ & $2.04 \pm 0.15$ & $2.12 \pm 0.22$ & $2.82 \pm 0.41$ & $2.63 \pm 0.28$ & $2.77 \pm 0.41$ & $2.08 \pm 0.24$ & $1.85 \pm 0.17$ & $2.30 \pm 0.22$ \\
\hline$-\mathrm{CHO}(\mathrm{mmol} / \mathrm{L})^{4}$ & $10.47 \pm 0.25$ & $7.66 \pm 0.15$ & $8.85 \pm 0.07$ & $10.49 \pm 0.81$ & $10.58 \pm 1.45$ & $10.72 \pm 0.56$ & $9.88 \pm 1.01$ & $9.74 \pm 0.07$ & $9.46 \pm 0.13$ \\
\hline $\mathrm{EFA}(\mu \mathrm{mol} / \mathrm{L})^{5}$ & $170.45 \pm 22.73^{b}$ & $56.82 \pm 6.56^{\mathrm{a}}$ & $79.55 \pm 6.56^{\mathrm{a}}$ & $196.97 \pm 23.04^{b}$ & $242.42 \pm 26.52^{\mathrm{b}}$ & $223.48 \pm 15.15^{\mathrm{b}}$ & $178.03 \pm 26.52^{b}$ & $193.18 \pm 13.12^{\mathrm{b}}$ & $193.18 \pm 6.56^{b}$ \\
\hline $\mathrm{LT}(\mathrm{U} / \mathrm{L})^{6}$ & $1.96 \pm 0.23^{\mathrm{a}}$ & $2.75 \pm 0.16^{\mathrm{a}}$ & $3.05 \pm 0.16^{\mathrm{a}}$ & $3.37 \pm 0.32^{\mathrm{a}}$ & $2.31 \pm 0.15^{\mathrm{a}}$ & $3.04 \pm 0.45^{\mathrm{a}}$ & $1.77 \pm 0.28^{\mathrm{a}}$ & $5.94 \pm 0.69^{\mathrm{b}}$ & $2.99 \pm 0.19^{\mathrm{a}}$ \\
\hline $\mathrm{ST}(\mathrm{U} / \mathrm{L})^{7}$ & $1.64 \pm 0.09^{\mathrm{abc}}$ & $1.84 \pm 0.20^{\mathrm{abc}}$ & $2.20 \pm 0.34^{\mathrm{bc}}$ & $2.05 \pm 0.22^{\mathrm{abc}}$ & $2.46 \pm 0.14^{\mathrm{c}}$ & $1.69 \pm 0.20^{\mathrm{abc}}$ & $1.44 \pm 0.13^{\mathrm{ab}}$ & $1.19 \pm 0.01^{\mathrm{a}}$ & $1.64 \pm 0.09^{\mathrm{abc}}$ \\
\hline
\end{tabular}

Values are mean $\pm \mathrm{SE}(\mathrm{n}=3)$. Means values in the same row with different superscripts are significantly different $(P<0.05)$. ND, not detected.

${ }^{1}$ HDL: high-density lipoprotein; ${ }^{2}$ LDL: low-density lipoprotein; ${ }^{3}$ TG: triglyceride; ${ }^{4}$ T-CHO: total-cholesterol; ${ }^{5}$ NEFA: non-esterified fatty acid;

${ }^{6} \mathrm{ALT}$ : alanine aminotransferase; ${ }^{7} \mathrm{AST}$ : aspartate aminotransferase.

FO, fish oil; CO, coconut oil; PO, palm oil; OTO, camellia oil; OO, olive oil; CNO, canola oil; PNO, peanut oil; LO, linseed oil; PFO, perilla oil. 
Table 5. Antioxidation parameters in serum and liver of juvenile pompano T. ovatus fed the experimental diets for 8 weeks.

\begin{tabular}{|c|c|c|c|c|c|c|c|c|c|}
\hline \multirow{2}{*}{ Parameter } & \multicolumn{9}{|c|}{ Dietary treatment } \\
\hline & FO & $\mathrm{CO}$ & $\mathrm{PO}$ & OTO & $\mathrm{OO}$ & $\mathrm{CNO}$ & PNO & $\mathrm{LO}$ & $\mathrm{PFO}$ \\
\hline \multicolumn{10}{|l|}{ Serum } \\
\hline $\operatorname{MDA}(\mathrm{nmol} / \mathrm{mL})^{1}$ & $8.85 \pm 0.24^{\mathrm{bc}}$ & $7.62 \pm 0.15^{\mathrm{ab}}$ & $9.41 \pm 0.3^{\mathrm{c}}$ & $8.51 \pm 0.20^{\mathrm{abc}}$ & $8.35 \pm 0.24^{\mathrm{abc}}$ & $8.40 \pm 0.35^{\mathrm{abc}}$ & $7.34 \pm 0.06^{\mathrm{a}}$ & $8.51 \pm 0.34^{\mathrm{abc}}$ & $7.73 \pm 0.39^{\mathrm{ab}}$ \\
\hline GSH-PX $(\mu \mathrm{mol} / \mathrm{L})^{2}$ & $244.91 \pm 8.73^{\mathrm{c}}$ & $245.59 \pm 4.79^{c}$ & $168.29 \pm 3.13^{\mathrm{a}}$ & $207.29 \pm 8.54^{\mathrm{b}}$ & $210.71 \pm 4.93^{\mathrm{bc}}$ & $206.60 \pm 5.85^{b}$ & $203.87 \pm 9.87^{\mathrm{ab}}$ & $207.29 \pm 4.10^{\mathrm{b}}$ & $234.65 \pm 11.87^{\mathrm{bc}}$ \\
\hline $\mathrm{CAT}(\mathrm{U} / \mathrm{mL})^{3}$ & $26.30 \pm 0.55^{b}$ & $25.97 \pm 1.33^{b}$ & $18.64 \pm 1.42^{\mathrm{a}}$ & $25.58 \pm 0.24^{b}$ & $23.59 \pm 1.01^{b}$ & $24.25 \pm 1.31^{\mathrm{b}}$ & $24.84 \pm 0.54^{b}$ & $26.48 \pm 0.24^{\mathrm{b}}$ & $27.81 \pm 0.60^{b}$ \\
\hline $\mathrm{SOD}(\mathrm{U} / \mathrm{mL})^{4}$ & $13.29 \pm 0.35^{\mathrm{bcd}}$ & $15.53 \pm 0.43^{\mathrm{d}}$ & $11.10 \pm 0.20^{\mathrm{ab}}$ & $14.16 \pm 0.60^{\mathrm{cd}}$ & $14.04 \pm 0.86^{\mathrm{cd}}$ & $13.09 \pm 0.20^{\mathrm{abcd}}$ & $10.36 \pm 0.88^{\mathrm{a}}$ & $12.08 \pm 0.80^{\mathrm{abc}}$ & $13.25 \pm 0.22^{\mathrm{bcd}}$ \\
\hline $\mathrm{T}-\mathrm{AOC}(\mathrm{mM})^{5}$ & $0.52 \pm 0.05^{\mathrm{c}}$ & $0.53 \pm 0.01^{\mathrm{c}}$ & $0.28 \pm 0.02^{\mathrm{ab}}$ & $0.38 \pm 0.04^{\mathrm{abc}}$ & $0.43 \pm 0.03^{\mathrm{bc}}$ & $0.43 \pm 0.0 .3^{b c}$ & $0.22 \pm 0.02^{\mathrm{a}}$ & $0.31 \pm 0.05^{\mathrm{ab}}$ & $0.54 \pm 0.05^{\mathrm{c}}$ \\
\hline \multicolumn{10}{|l|}{ Liver } \\
\hline MDA (nmol / mgprot) $)^{1}$ & $1.97 \pm 0.45^{\mathrm{ab}}$ & $0.94 \pm 0.04^{\mathrm{a}}$ & $2.88 \pm 0.04^{\mathrm{b}}$ & $1.43 \pm 0.24^{\mathrm{a}}$ & $1.02 \pm 0.03^{\mathrm{a}}$ & $1.08 \pm 0.09^{\mathrm{a}}$ & $1.79 \pm 0.02^{\mathrm{ab}}$ & $2.61 \pm 0.25^{b}$ & $1.87 \pm 0.25^{\mathrm{ab}}$ \\
\hline GSH-PX (U / mgprot $)^{2}$ & $499.77 \pm 9.62^{\mathrm{c}}$ & $453.09 \pm 27.70^{\mathrm{c}}$ & $285.45 \pm 25.38^{\mathrm{a}}$ & $310.84 \pm 12.66^{\mathrm{ab}}$ & $337.28 \pm 27.43^{\mathrm{ab}}$ & $395.86 \pm 2.58^{\mathrm{bc}}$ & $344.77 \pm 12.46^{\mathrm{ab}}$ & $267.82 \pm 22.38^{\mathrm{a}}$ & $338.84 \pm 29.73^{\mathrm{ab}}$ \\
\hline CAT (U / mgprot $)^{3}$ & $19.72 \pm 0.86^{\mathrm{c}}$ & $16.88 \pm 0.69^{\mathrm{bc}}$ & $11.64 \pm 0.60^{\mathrm{a}}$ & $14.97 \pm 0.61^{\mathrm{ab}}$ & $14.26 \pm 0.98^{\mathrm{ab}}$ & $14.78 \pm 0.94^{\mathrm{ab}}$ & $19.26 \pm 0.28^{c}$ & $13.78 \pm 0.75^{\mathrm{ab}}$ & $17.33 \pm 0.84^{\mathrm{bc}}$ \\
\hline SOD (U / mgprot $)^{4}$ & $12.17 \pm 0.61^{\mathrm{bcd}}$ & $15.71 \pm 0.10^{\mathrm{e}}$ & $11.58 \pm 1.01^{\mathrm{bc}}$ & $14.56 \pm 0.24^{\mathrm{de}}$ & $8.98 \pm 0.47^{\mathrm{a}}$ & $11.54 \pm 0.31^{\mathrm{bc}}$ & $12.69 \pm 0.28^{\mathrm{bcd}}$ & $10.31 \pm 0.55^{\mathrm{ab}}$ & $12.81 \pm 0.16^{\mathrm{cd}}$ \\
\hline T-AOC (mM / mgprot $)^{5}$ & $0.69 \pm 0.02^{\text {cd }}$ & $0.72 \pm 0.02^{\text {cd }}$ & $0.68 \pm 0.01^{\mathrm{cd}}$ & $0.71 \pm 0.01^{\text {cd }}$ & $0.50 \pm 0.01^{\mathrm{a}}$ & $0.62 \pm 0.05^{\mathrm{bc}}$ & $0.78 \pm 0.01^{\mathrm{d}}$ & $0.57 \pm 0.01^{\mathrm{ab}}$ & $0.69 \pm 0.03^{\text {cd }}$ \\
\hline
\end{tabular}

Values are mean $\pm \mathrm{SE}(\mathrm{n}=3)$. Means values in the same row with different superscripts are significantly different $(P<0.05)$.

${ }^{1}$ MDA: malondialdehyde; ${ }^{2}$ GSH-PX: glutathione peroxidase activity; ${ }^{3} \mathrm{CAT}$ : catalase activity; ${ }^{4}$ SOD: superoxide dismutase activity; ${ }^{5} \mathrm{~T}$-AOC: total antioxidant capacity activity.

FO, fish oil; CO, coconut oil; PO, palm oil; OTO, camellia oil; OO, olive oil; CNO, canola oil; PNO, peanut oil; LO, linseed oil; PFO, perilla oil. 
Table 6. Tissue lipid deposition of total lipid ( $\mathrm{mg} / \mathrm{g}$ ), neutral lipid (mg / g) and polar lipid (mg / g) of juvenile Trachinotus ovatus fed with experimental diets for 8 weeks.

\begin{tabular}{|c|c|c|c|c|c|c|c|c|c|}
\hline \multirow{2}{*}{ Parameter } & \multicolumn{9}{|l|}{ Dietary treatment } \\
\hline & FO & $\mathrm{CO}$ & $\mathrm{PO}$ & OTO & $\mathrm{OO}$ & $\mathrm{CNO}$ & PNO & LO & $\mathrm{PFO}$ \\
\hline \multicolumn{10}{|l|}{ Liver } \\
\hline Total lipid & $215.21 \pm 10.88^{\mathrm{ab}}$ & $252.11 \pm 17.63^{\mathrm{bc}}$ & $285.06 \pm 2.67^{\mathrm{c}}$ & $375.33 \pm 2.18^{\mathrm{d}}$ & $360.72 \pm 4.91^{\mathrm{d}}$ & $275.78 \pm 6.34^{c}$ & $187.48 \pm 4.41^{\mathrm{a}}$ & $246.28 \pm 12.51^{\mathrm{bc}}$ & $335.19 \pm 12.37^{d}$ \\
\hline $\mathrm{NL}^{1}$ & $166.53 \pm 3.22^{\mathrm{ab}}$ & $202.72 \pm 10.73^{\mathrm{bc}}$ & $212.29 \pm 3.73^{c}$ & $291.32 \pm 2.43^{\mathrm{e}}$ & $296.08 \pm 15.69^{\mathrm{e}}$ & $232.41 \pm 8.42^{\mathrm{cd}}$ & $162.06 \pm 3.32^{\mathrm{a}}$ & $221.62 \pm 8.87^{c}$ & $263.48 \pm 6.33^{\mathrm{de}}$ \\
\hline $\mathrm{PL}^{2}$ & $48.67 \pm 8.36^{\mathrm{abc}}$ & $49.39 \pm 7.12^{\mathrm{abc}}$ & $72.77 \pm 1.2^{\mathrm{bc}}$ & $83.98 \pm 1.02^{\mathrm{c}}$ & $64.64 \pm 11.07^{\mathrm{bc}}$ & $43.37 \pm 4.21^{\mathrm{ab}}$ & $25.42 \pm 3.64^{\mathrm{a}}$ & $24.66 \pm 5.01^{\mathrm{a}}$ & $71.71 \pm 13.09^{\mathrm{bc}}$ \\
\hline $\mathrm{NL} / \mathrm{PL}^{3}$ & $3.64 \pm 0.65^{\mathrm{a}}$ & $4.21 \pm 0.38^{\mathrm{a}}$ & $2.92 \pm 0.99^{\mathrm{a}}$ & $3.47 \pm 0.06^{\mathrm{a}}$ & $4.89 \pm 0.93^{\mathrm{a}}$ & $5.49 \pm 0.70^{\mathrm{a}}$ & $6.64 \pm 0.92^{\mathrm{ab}}$ & $9.66 \pm 1.65^{b}$ & $3.96 \pm 0.65^{\mathrm{a}}$ \\
\hline \multicolumn{10}{|c|}{ Dorsal muscle } \\
\hline Total lipid & $58.92 \pm 1.90^{\mathrm{bc}}$ & $66.45 \pm 1.78^{c}$ & $70.11 \pm 0.47^{\text {cde }}$ & $83.58 \pm 3.56^{\mathrm{e}}$ & $81.91 \pm 6.85^{\mathrm{de}}$ & $61.13 \pm 1.73^{\mathrm{bc}}$ & $68.05 \pm 1.63^{\mathrm{cd}}$ & $37.76 \pm 2.26^{\mathrm{a}}$ & $50.44 \pm 2.62^{\mathrm{ab}}$ \\
\hline $\mathrm{NL}^{1}$ & $49.36 \pm 1.11^{\mathrm{bc}}$ & $61.24 \pm 1.61^{\mathrm{cd}}$ & $64.16 \pm 0.32^{\mathrm{cd}}$ & $76.64 \pm 4.13^{\mathrm{d}}$ & $75.01 \pm 7.35^{\mathrm{d}}$ & $55.68 \pm 1.61^{\mathrm{bc}}$ & $63.28 \pm 1.99^{\mathrm{cd}}$ & $30.06 \pm 1.89^{\mathrm{a}}$ & $41.09 \pm 1.70^{\mathrm{ab}}$ \\
\hline $\mathrm{PL}^{2}$ & $9.56 \pm 0.79^{\mathrm{c}}$ & $5.21 \pm 0.29^{\mathrm{ab}}$ & $5.96 \pm 0.18^{\mathrm{ab}}$ & $6.94 \pm 0.75^{\mathrm{abc}}$ & $6.90 \pm 0.51^{\mathrm{abc}}$ & $5.45 \pm 0.20^{\mathrm{ab}}$ & $4.77 \pm 3.17^{\mathrm{a}}$ & $7.69 \pm 0.48^{\mathrm{bc}}$ & $9.35 \pm 1.05^{\mathrm{c}}$ \\
\hline $\mathrm{NL} / \mathrm{PL}^{3}$ & $5.21 \pm 0.29^{\mathrm{ab}}$ & $11.80 \pm 0.54^{\mathrm{b}}$ & $10.79 \pm 0.28^{\mathrm{b}}$ & $11.40 \pm 1.68^{\mathrm{b}}$ & $11.16 \pm 1.96^{\mathrm{b}}$ & $10.23 \pm 0.32^{\mathrm{b}}$ & $13.50 \pm 1.37^{\mathrm{b}}$ & $3.91 \pm 0.18^{\mathrm{a}}$ & $4.48 \pm 0.39^{\mathrm{a}}$ \\
\hline \multicolumn{10}{|c|}{ Ventral muscle } \\
\hline Total lipid & $186.99 \pm 1.93^{\mathrm{c}}$ & $99.9414 \mathcal{B} .8080^{\mathrm{a}}$ & $1099904.933283927^{\mathrm{a}}$ & 1091107640489 & $1^{\mathrm{bc}} 15991019$ & $23^{369} 97.910019$ & 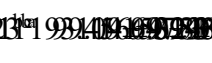 & 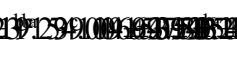 & 31) \\
\hline $\mathrm{NL}^{1}$ & $172.35 \pm 2.52^{\mathrm{b}}$ & $83.37 \pm 3.82^{\mathrm{a}}$ & $90.43 \pm 3.47^{\mathrm{a}}$ & $146.52 \pm 11.76^{\mathrm{bc}}$ & $134.90 \pm 4.69^{\mathrm{b}}$ & $78.98 \pm 7.63^{\mathrm{a}}$ & $170.99 \pm 9.93^{b}$ & $137.02 \pm 3.61^{b}$ & $133.13 \pm 6.04^{\mathrm{b}}$ \\
\hline $\mathrm{PL}^{2}$ & $14.64 \pm 1.30^{\mathrm{a}}$ & $15.77 \pm 0.90^{\mathrm{ab}}$ & $19.51 \pm 1.01^{\mathrm{ab}}$ & $19.57 \pm 1.11^{\mathrm{ab}}$ & $18.62 \pm 3.10^{\mathrm{ab}}$ & $18.48 \pm 0.52^{\mathrm{ab}}$ & $22.45 \pm 1.24^{\mathrm{b}}$ & $16.94 \pm 0.62^{\mathrm{ab}}$ & $14.05 \pm 0.83^{\mathrm{a}}$ \\
\hline $\mathrm{NL} / \mathrm{PL}^{3}$ & $11.99 \pm 1.26^{\mathrm{c}}$ & $5.33 \pm 0.43^{\mathrm{ab}}$ & $4.67 \pm 0.34^{\mathrm{a}}$ & $7.59 \pm 0.99^{\mathrm{abc}}$ & $7.79 \pm 1.68^{\mathrm{abc}}$ & $4.26 \pm 0.31^{\mathrm{a}}$ & $7.70 \pm 0.82^{\mathrm{abc}}$ & $8.11 \pm 0.41^{\mathrm{abc}}$ & $9.59 \pm 0.95^{\mathrm{bc}}$ \\
\hline
\end{tabular}

Values are mean $\pm \mathrm{SE}(\mathrm{n}=3)$. Means values in the same row with different superscripts are significantly different $(P<0.05)$.

${ }^{1}$ NL: neutral lipids; ${ }^{2}$ PL: polar lipids; ${ }^{3} \mathrm{NL} / \mathrm{PL}$ : the ratio of neutral lipids to polar lipids.

FO, fish oil; CO, coconut oil; PO, palm oil; OTO, camellia oil; OO, olive oil; CNO, canola oil; PNO, peanut oil; LO, linseed oil; PFO, perilla oil. 


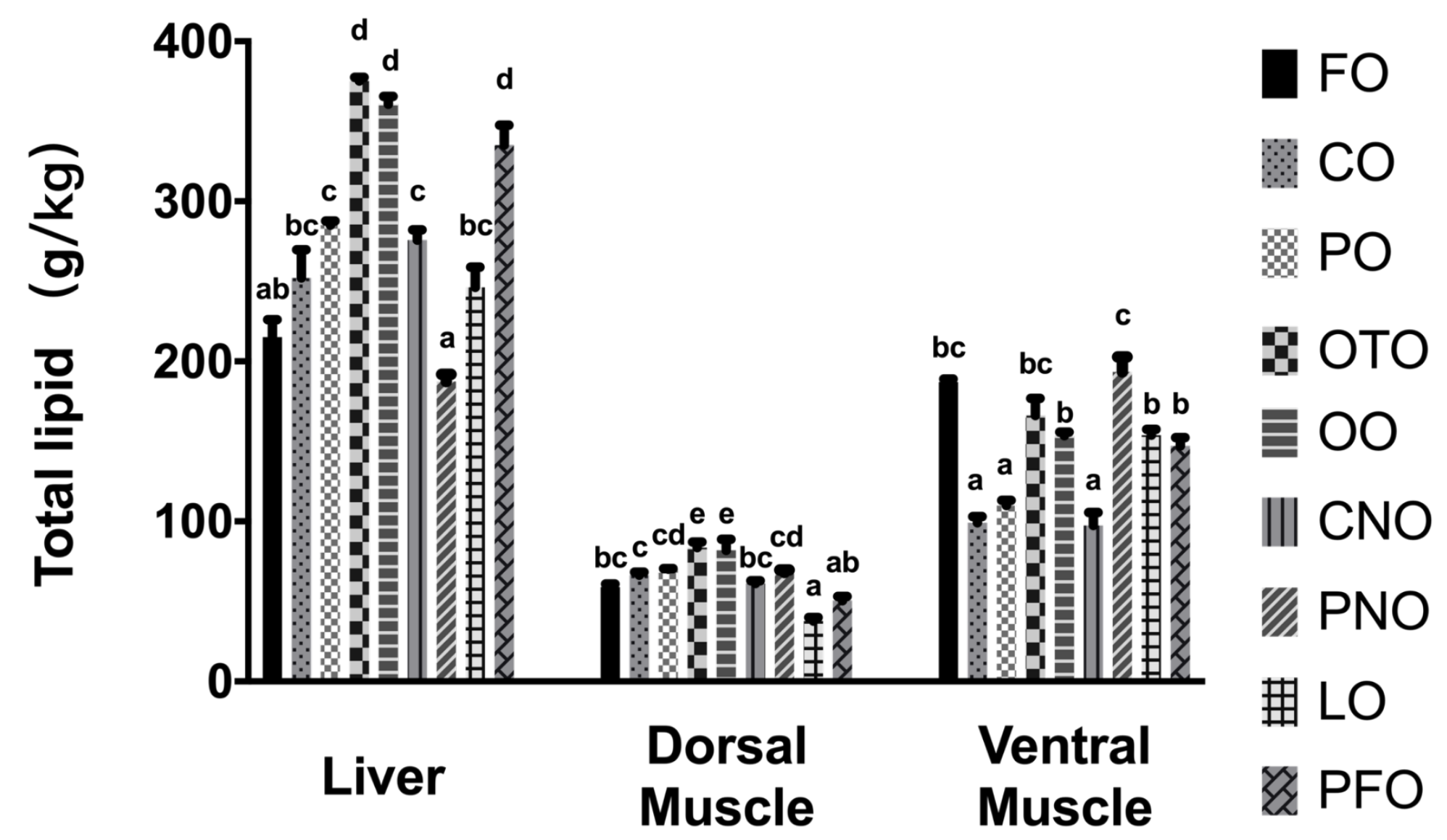

Fig. 1. Tissue total lipid (g / kg, wet matter basis) in liver, dorsal muscle and ventral muscle of juvenile Trachinotus ovatus fed different experimental diets for 8 weeks.

Values are mean $\pm \mathrm{SE}(\mathrm{n}=3)$. Means values in the same row with different superscripts are significantly different $(P<0.05)$.

FO, fish oil; CO, coconut oil; PO, palm oil; OTO, oil-tea camellia oil; OO, olive oil; CNO, canola oil; PNO, peanut oil; LO, linseed oil; PFO, perilla oil. 

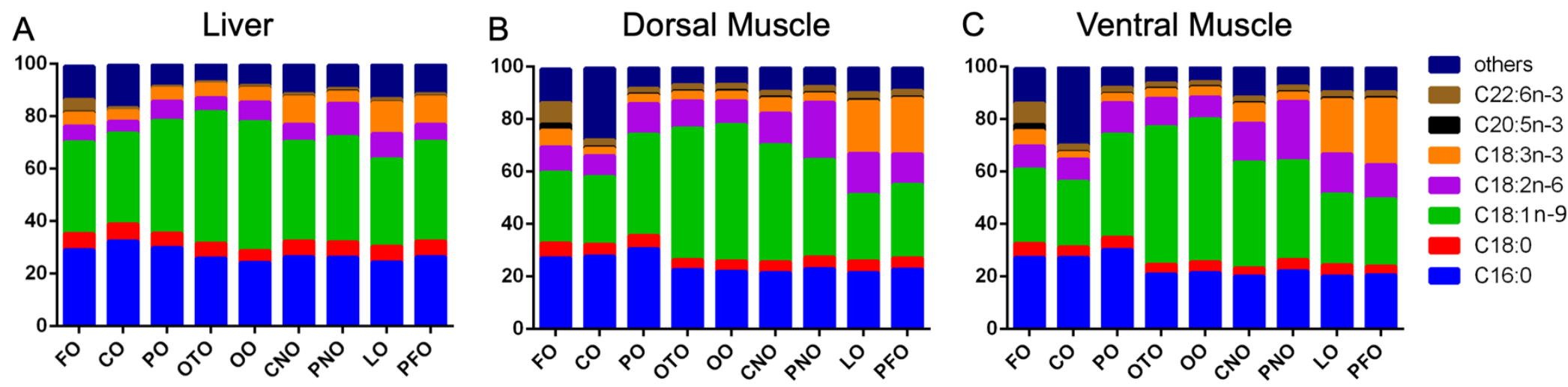

Proportions (\% total fatty acids) of selected fatty acids in neutral lipid of liver (A), dorsal muscle (B) and ventral muscle (C) of pompano fed the experimental diets for 8 weeks.

Note: complete neutral lipid fatty acid composition is detailed in Supplementary Table 1.

FO, fish oil; CO, coconut oil; PO, palm oil; OTO, oil-tea camellia oil; OO, olive oil; CNO, canola oil; PNO, peanut oil; LO, linseed oil; PFO, perilla oil. 

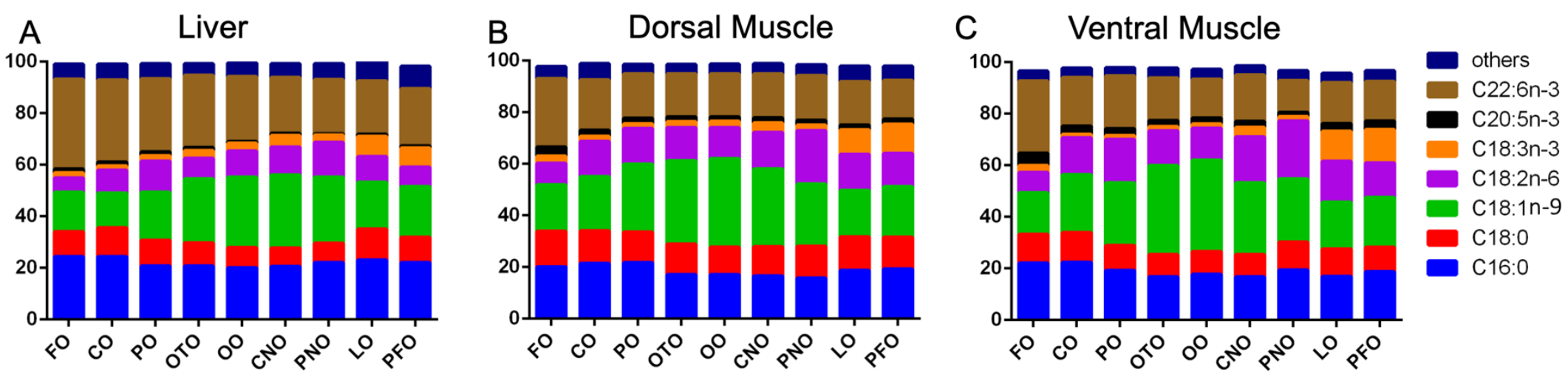

Fig. 3. Proportions (\% total fatty acids) of selected fatty acids in polar lipid of liver (A), dorsal muscle (B) and ventral muscle (C) of pompano fed the experimental diets for 8 weeks. Note: complete polar lipid fatty acid composition is detailed in Supplementary Table 1.

FO, fish oil; CO, coconut oil; PO, palm oil; OTO, oil-tea camellia oil; OO, olive oil; CNO, canola oil; PNO, peanut oil; LO, linseed oil; PFO, perilla oil. 

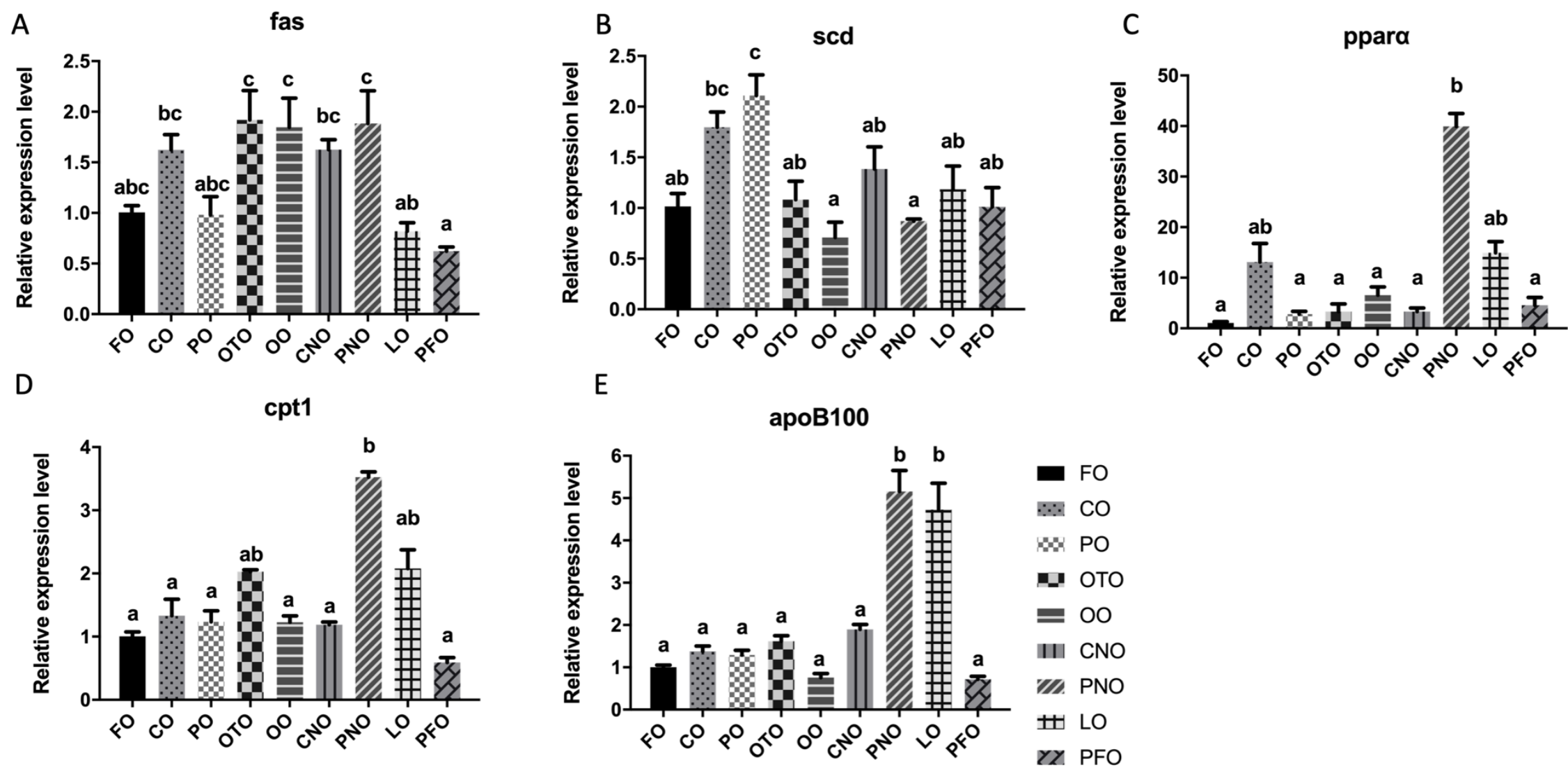

Fig. 4. Relative mRNA expression level of $f a s$ (A), scd (B), ppara (C), cpt1 (D) and apoB100 (E) in liver of pompano fed the experimental diets for 8 weeks. Values of columns for the same gene with different superscripts are significantly different $(P<0.05)$.

FO, fish oil; CO, coconut oil; PO, palm oil; OTO, oil-tea camellia oil; OO, olive oil; CNO, canola oil; PNO, peanut oil; LO, linseed oil; PFO, perilla oil. 
Supplementary Table 1 . The fatty acid composition of neutral lipids of liver ( $\%$ total fatty acids).

\begin{tabular}{|c|c|c|c|c|c|c|c|c|c|}
\hline \multirow[t]{2}{*}{ Parameter } & \multicolumn{9}{|l|}{ Dietary treatment } \\
\hline & $\mathrm{FO}$ & $\mathrm{CO}$ & $\mathrm{PO}$ & OTO & $\mathrm{OO}$ & $\mathrm{CNO}$ & PNO & LO & PFO \\
\hline $\mathrm{C} 12: 0$ & ND & $1.71 \pm 0.21^{\mathrm{b}}$ & $0.05 \pm 0.01^{\mathrm{a}}$ & $0.02 \pm 0.00^{\mathrm{a}}$ & $0.01 \pm 0.00^{\mathrm{a}}$ & $0.01 \pm 0.00^{\mathrm{a}}$ & ND & ND & ND \\
\hline C16:0 & $26.62 \pm 0.42^{\mathrm{ab}}$ & $30.94 \pm 0.40^{c}$ & $28.81 \pm 0.68^{b c}$ & $25.21 \pm 0.11^{\mathrm{ab}}$ & $23.58 \pm 0.43^{\mathrm{a}}$ & $24.01 \pm 0.64^{\mathrm{a}}$ & $25.34 \pm 1.96^{\mathrm{ab}}$ & $25.34 \pm 0.63^{\mathrm{a}}$ & $25.31 \pm 1.00^{\mathrm{ab}}$ \\
\hline C16:1n-9 & $3.29 \pm 0.06^{\mathrm{b}}$ & $3.34 \pm 0.27^{\mathrm{b}}$ & $2.21 \pm 0.17^{\mathrm{a}}$ & $1.85 \pm 0.03^{\mathrm{a}}$ & $2.00 \pm 0.05^{\mathrm{a}}$ & $1.84 \pm 0.08^{a}$ & $1.83 \pm 0.10^{\mathrm{a}}$ & $1.64 \pm 0.07^{\mathrm{a}}$ & $1.93 \pm 0.11^{\mathrm{a}}$ \\
\hline C18:0 & $5.64 \pm 0.21^{\mathrm{ab}}$ & $6.27 \pm 0.53^{b}$ & $5.26 \pm 0.35^{\mathrm{ab}}$ & $5.45 \pm 0.05^{\mathrm{ab}}$ & $4.28 \pm 0.27^{\mathrm{a}}$ & $4.64 \pm 0.28^{\mathrm{ab}}$ & $5.67 \pm 0.61^{\mathrm{ab}}$ & $5.60 \pm 0.56^{\mathrm{ab}}$ & $5.74 \pm 0.14^{\mathrm{ab}}$ \\
\hline C18:1n-9 & $32.44 \pm 1.00^{\mathrm{a}}$ & $33.51 \pm 1.50^{\mathrm{ab}}$ & $41.45 \pm 0.80^{\mathrm{cd}}$ & $48.55 \pm 0.05^{\mathrm{f}}$ & $47.61 \pm 1.98^{\mathrm{ef}}$ & $42.61 \pm 0.62^{\mathrm{de}}$ & $38.49 \pm 0.55^{\mathrm{bcd}}$ & $31.75 \pm 1.43^{\mathrm{a}}$ & $36.08 \pm 0.50^{\mathrm{abc}}$ \\
\hline C18:2n-6 & $5.93 \pm 0.19^{a}$ & $4.51 \pm 0.21^{\mathrm{a}}$ & $7.28 \pm 0.53^{\mathrm{ab}}$ & $5.50 \pm 0.02^{\mathrm{a}}$ & $7.58 \pm 2.27^{\mathrm{ab}}$ & $8.28 \pm 0.85^{\mathrm{ab}}$ & $12.37 \pm 2.37^{b}$ & $9.43 \pm 0.63^{\mathrm{ab}}$ & $6.40 \pm 0.34^{\mathrm{a}}$ \\
\hline C20:0 & $0.25 \pm 0.01^{\mathrm{ab}}$ & $0.23 \pm 0.01^{\mathrm{ab}}$ & $0.22 \pm 0.01^{\mathrm{ab}}$ & $0.18 \pm 0.00^{\mathrm{a}}$ & $0.15 \pm 0.07^{\mathrm{a}}$ & $0.24 \pm 0.00^{\mathrm{ab}}$ & $0.34 \pm 0.01^{b}$ & $0.20 \pm 0.01^{\mathrm{a}}$ & $0.20 \pm 0.00^{\mathrm{a}}$ \\
\hline C20:1n-9 & $0.03 \pm 0.01$ & $0.02 \pm 0.02$ & $0.05 \pm 0.00$ & $0.05 \pm 0.00$ & $0.02 \pm 0.01$ & $0.02 \pm 0.01$ & $0.04 \pm 0.01$ & $0.04 \pm 0.01$ & $0.03 \pm 0.01$ \\
\hline C18:3n-3 & $0.03 \pm 0.01^{\mathrm{a}}$ & $2.83 \pm 1.39^{\mathrm{ab}}$ & $3.89 \pm 0.21^{\mathrm{ab}}$ & $4.32 \pm 0.32^{\mathrm{abc}}$ & $4.77 \pm 0.35^{\mathrm{bc}}$ & $5.14 \pm 0.24^{b c}$ & $5.44 \pm 0.36^{\mathrm{bc}}$ & $4.90 \pm 0.56^{\mathrm{bc}}$ & $8.74 \pm 2.29^{c}$ \\
\hline$C 20: 2 n-6$ & $1.73 \pm 0.05^{\mathrm{a}}$ & $1.57 \pm 0.13^{\mathrm{a}}$ & $1.79 \pm 0.03^{\mathrm{a}}$ & $1.39 \pm 0.06^{\mathrm{a}}$ & $1.65 \pm 0.25^{\mathrm{a}}$ & $1.95 \pm 0.21^{\mathrm{ab}}$ & $2.90 \pm 0.44^{\mathrm{b}}$ & $2.04 \pm 0.20^{\mathrm{ab}}$ & $1.46 \pm 0.06^{\mathrm{a}}$ \\
\hline$C 22: 1 n-9$ & $0.82 \pm 0.03^{\mathrm{b}}$ & $0.06 \pm 0.00^{\mathrm{a}}$ & $0.04 \pm 0.00^{\mathrm{a}}$ & $0.02 \pm 0.01^{\mathrm{a}}$ & $0.04 \pm 0.00^{\mathrm{a}}$ & $0.02 \pm 0.01^{\mathrm{a}}$ & $0.05 \pm 0.00^{\mathrm{a}}$ & $0.04 \pm 0.02^{\mathrm{a}}$ & $0.08 \pm 0.00^{\mathrm{a}}$ \\
\hline$C 20: 3 n-3$ & $2.50 \pm 0.02^{\mathrm{ab}}$ & $1.95 \pm 0.08^{a}$ & $1.93 \pm 0.06^{\mathrm{a}}$ & $1.82 \pm 0.04^{\mathrm{a}}$ & $2.04 \pm 0.17^{\mathrm{a}}$ & $3.64 \pm 0.20^{\mathrm{b}}$ & $1.79 \pm 0.02^{\mathrm{a}}$ & $6.68 \pm 0.79^{c}$ & $5.72 \pm 0.18^{c}$ \\
\hline$C 20: 4 n-6$ & $0.13 \pm 0.02^{\mathrm{bc}}$ & $0.07 \pm 0.01^{\mathrm{abc}}$ & $0.05 \pm 0.00^{\mathrm{a}}$ & $0.05 \pm 0.00^{\mathrm{ab}}$ & $0.12 \pm 0.01^{\mathrm{abc}}$ & $0.13 \pm 0.01^{\mathrm{abc}}$ & $0.13 \pm 0.03^{\mathrm{c}}$ & $0.09 \pm 0.02^{\mathrm{abc}}$ & $0.06 \pm 0.03^{\mathrm{abc}}$ \\
\hline$C 20: 4 n-3$ & $0.55 \pm 0.05^{\mathrm{bc}}$ & $0.41 \pm 0.08^{\mathrm{abc}}$ & $0.36 \pm 0.02^{\mathrm{abc}}$ & $0.22 \pm 0.01^{\mathrm{a}}$ & $0.32 \pm 0.07^{\mathrm{abc}}$ & $0.29 \pm 0.03^{\mathrm{ab}}$ & $0.59 \pm 0.11^{b c}$ & $0.60 \pm 0.05^{\mathrm{c}}$ & $0.34 \pm 0.06^{\mathrm{abc}}$ \\
\hline $\mathrm{C} 24: 0$ & $0.36 \pm 0.01^{\mathrm{b}}$ & $0.08 \pm 0.01^{\mathrm{a}}$ & $0.06 \pm 0.00^{\mathrm{a}}$ & $0.06 \pm 0.01^{\mathrm{a}}$ & $0.08 \pm 0.00^{\mathrm{a}}$ & $0.09 \pm 0.00^{\mathrm{a}}$ & $0.08 \pm 0.01^{\mathrm{a}}$ & $0.10 \pm 0.02^{\mathrm{a}}$ & $0.08 \pm 0.02^{\mathrm{a}}$ \\
\hline$C 20: 5 n-3$ & $1.44 \pm 0.06^{\mathrm{d}}$ & $0.75 \pm 0.04^{\mathrm{a}}$ & $0.82 \pm 0.01^{\mathrm{ab}}$ & $0.72 \pm 0.05^{\mathrm{a}}$ & $0.86 \pm 0.05^{\mathrm{ab}}$ & $1.42 \pm 0.02^{\mathrm{d}}$ & $0.81 \pm 0.05^{\mathrm{ab}}$ & $1.22 \pm 0.10^{\mathrm{cd}}$ & $1.06 \pm 0.02^{\mathrm{bc}}$ \\
\hline$C 22: 5 n-3$ & $1.00 \pm 0.10^{\mathrm{b}}$ & $0.14 \pm 0.02^{\mathrm{a}}$ & $0.16 \pm 0.02^{\mathrm{a}}$ & $0.16 \pm 0.00^{\mathrm{a}}$ & $0.14 \pm 0.01^{\mathrm{a}}$ & $0.11 \pm 0.01^{\mathrm{a}}$ & $0.14 \pm 0.03^{\mathrm{a}}$ & $0.22 \pm 0.02^{\mathrm{a}}$ & $0.15 \pm 0.03^{\mathrm{a}}$ \\
\hline$C 22: 6 n-3$ & $4.44 \pm 0.19^{b}$ & $1.04 \pm 0.05^{\mathrm{a}}$ & $0.77 \pm 0.05^{\mathrm{a}}$ & $0.77 \pm \quad 0.01^{\mathrm{a}}$ & $0.84 \pm 0.01^{\mathrm{a}}$ & $0.87 \pm 0.10^{\mathrm{a}}$ & $0.99 \pm 0.07^{\mathrm{a}}$ & $1.28 \pm 0.18^{\mathrm{a}}$ & $1.10 \pm 0.10^{\mathrm{a}}$ \\
\hline$\Sigma \mathrm{SFA}^{1}$ & $34.68 \pm 0.66^{\mathrm{ab}}$ & $45.71 \pm 0.86^{\mathrm{c}}$ & $35.76 \pm 0.61^{b}$ & $32.00 \pm 0.15^{\mathrm{ab}}$ & $29.25 \pm 0.54^{\mathrm{a}}$ & $30.13 \pm 0.89^{\mathrm{ab}}$ & $32.42 \pm 2.59^{\mathrm{ab}}$ & $30.10 \pm 1.20^{\mathrm{a}}$ & $32.28 \pm 0.94^{\mathrm{ab}}$ \\
\hline$\Sigma \mathrm{MUFA}^{2}$ & $36.58 \pm 0.91^{\mathrm{ab}}$ & $36.93 \pm 1.32^{\mathrm{ab}}$ & $43.75 \pm 0.73^{c}$ & $50.47 \pm 0.07^{\mathrm{e}}$ & $49.66 \pm 1.96^{\mathrm{de}}$ & $44.50 \pm 0.71^{\mathrm{cd}}$ & $40.41 \pm 0.66^{\mathrm{bc}}$ & $33.47 \pm 1.50^{\mathrm{a}}$ & $38.09 \pm 0.60^{\mathrm{ab}}$ \\
\hline$\Sigma \mathrm{PUFA}^{3}$ & $22.06 \pm 0.46^{\mathrm{abcd}}$ & $14.29 \pm 0.52^{\mathrm{a}}$ & $17.62 \pm 0.20^{\mathrm{abc}}$ & $15.81 \pm 0.17^{\mathrm{ab}}$ & $18.63 \pm 2.32^{\mathrm{abcd}}$ & $22.58 \pm 1.33^{\mathrm{bcd}}$ & $24.12 \pm 3.02^{\mathrm{cd}}$ & $33.28 \pm 2.39^{\mathrm{e}}$ & $26.77 \pm 1.36^{\mathrm{de}}$ \\
\hline$\Sigma \mathrm{n}-6 \mathrm{PUFA}^{4}$ & $7.94 \pm 0.24^{\mathrm{a}}$ & $6.22 \pm 0.33^{\mathrm{a}}$ & $9.18 \pm 0.54^{\mathrm{ab}}$ & $6.98 \pm 0.05^{\mathrm{a}}$ & $9.42 \pm 2.52^{\mathrm{ab}}$ & $10.42 \pm 1.04^{\mathrm{ab}}$ & $15.50 \pm 2.81^{b}$ & $11.65 \pm 0.81^{\mathrm{ab}}$ & $8.02 \pm 0.41^{\mathrm{a}}$ \\
\hline$\Sigma \mathrm{LC}^{-\mathrm{PUFA}^{6}}$ & $11.93 \pm 0.32^{\mathrm{d}}$ & $6.00 \pm 0.36^{\mathrm{ab}}$ & $5.93 \pm 0.13^{\mathrm{ab}}$ & $5.16 \pm 0.15^{\mathrm{a}}$ & $6.04 \pm 0.25^{\mathrm{ab}}$ & $8.47 \pm 0.34^{b c}$ & $7.45 \pm 0.70^{\mathrm{abc}}$ & $12.21 \pm 1.19^{d}$ & $9.99 \pm 0.42^{\mathrm{cd}}$ \\
\hline n-3/n-6 PUFA & $1.78 \pm 0.03^{\mathrm{cd}}$ & $1.30 \pm 0.06^{\mathrm{bc}}$ & $0.93 \pm 0.10^{\mathrm{ab}}$ & $1.26 \pm 0.01^{\mathrm{bc}}$ & $1.12 \pm 0.27^{\mathrm{ab}}$ & $1.19 \pm 0.09^{b}$ & $0.59 \pm 0.08^{\mathrm{a}}$ & $1.86 \pm 0.08^{\mathrm{de}}$ & $2.34 \pm 0.01^{\mathrm{e}}$ \\
\hline
\end{tabular}


Notes: Values are mean $\pm \mathrm{SE}(\mathrm{n}=3)$. Mean values in the same row with different superscripts are significantly different $(P<0.05)$. ND, no detected.

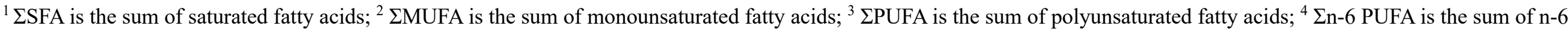
polyunsaturated fatty acids; ${ }^{5} \Sigma$ n-3 PUFA is the sum of n-3 polyunsaturated fatty acids; ${ }^{6} \Sigma$ LC-PUFA is the sum of long-chain polyunsaturated fatty acids.

FO, fish oil; CO, coconut oil; PO, palm oil; OTO, oil-tea camellia oil; OO, olive oil; CNO, canola oil; PNO, peanut oil; LO, linseed oil; PFO, perilla oil. 
Supplementary Table 2. The fatty acid composition of neutral lipids of dorsal muscle ( $\%$ total fatty acids).

\begin{tabular}{|c|c|c|c|c|c|c|c|c|c|}
\hline \multirow[t]{2}{*}{ Parameter } & \multicolumn{9}{|c|}{ Dietary treatment } \\
\hline & FO & $\mathrm{CO}$ & $\mathrm{PO}$ & OTO & $\mathrm{OO}$ & $\mathrm{CNO}$ & PNO & LO & PFO \\
\hline $\mathrm{C} 12: 0$ & ND & $9.65 \pm 0.63^{b}$ & $0.46 \pm 0.07^{\mathrm{a}}$ & $0.06 \pm 0.01^{\mathrm{a}}$ & $0.02 \pm 0.00^{\mathrm{a}}$ & ND & ND & ND & ND \\
\hline C14:0 & $3.00 \pm 0.07^{\mathrm{c}}$ & $9.94 \pm 0.15^{\mathrm{d}}$ & $2.05 \pm 0.07^{\mathrm{b}}$ & $1.42 \pm 0.07^{\mathrm{a}}$ & $1.32 \pm 0.02^{\mathrm{a}}$ & $1.49 \pm 0.04^{\mathrm{a}}$ & $1.33 \pm 0.01^{\mathrm{a}}$ & $1.37 \pm 0.08^{\mathrm{a}}$ & $1.27 \pm 0.01^{\mathrm{a}}$ \\
\hline C16:0 & $23.88 \pm 0.59^{\mathrm{bc}}$ & $26.17 \pm 0.38^{c}$ & $29.19 \pm 0.19^{d}$ & $21.47 \pm 0.86^{\mathrm{a}}$ & $20.61 \pm 0.27^{\mathrm{a}}$ & $20.05 \pm 0.60^{\mathrm{a}}$ & $21.62 \pm 0.03^{\mathrm{ab}}$ & $20.17 \pm 0.41^{\mathrm{a}}$ & $21.66 \pm 0.41^{\mathrm{ab}}$ \\
\hline C16:1n-9 & $4.11 \pm 0.09^{\mathrm{d}}$ & $3.31 \pm 0.07^{\mathrm{c}}$ & $2.62 \pm 0.11^{\mathrm{b}}$ & $2.31 \pm 0.16^{\mathrm{ab}}$ & $2.38 \pm 0.02^{\mathrm{ab}}$ & $2.13 \pm 0.04^{\mathrm{a}}$ & $2.18 \pm 0.02^{\mathrm{ab}}$ & $2.03 \pm 0.16^{\mathrm{a}}$ & $2.39 \pm 0.05^{\mathrm{ab}}$ \\
\hline C18:0 & $4.93 \pm 0.07^{b}$ & $4.24 \pm 0.05^{\mathrm{ab}}$ & $4.72 \pm 0.30^{\mathrm{b}}$ & $3.64 \pm 0.08^{\mathrm{a}}$ & $3.82 \pm 0.11^{\mathrm{a}}$ & $3.76 \pm 0.15^{\mathrm{a}}$ & $4.29 \pm 0.06^{\mathrm{ab}}$ & $4.26 \pm 0.22^{\mathrm{ab}}$ & $4.22 \pm 0.19^{\mathrm{ab}}$ \\
\hline C18:1n-9 & $24.30 \pm 1.52^{\mathrm{a}}$ & $24.34 \pm 0.33^{\mathrm{a}}$ & $36.92 \pm 0.40^{\mathrm{bc}}$ & $47.75 \pm 1.25^{\mathrm{d}}$ & $49.15 \pm 0.55^{\mathrm{d}}$ & $41.50 \pm 2.01^{\mathrm{c}}$ & $35.02 \pm 0.20^{\mathrm{b}}$ & $23.98 \pm 0.13^{\mathrm{a}}$ & $26.73 \pm 0.10^{\mathrm{a}}$ \\
\hline C18:2n-6 & $9.20 \pm 0.83^{\mathrm{ab}}$ & $7.80 \pm 0.03^{\mathrm{a}}$ & $11.26 \pm 0.13^{\mathrm{b}}$ & $10.35 \pm 0.28^{\mathrm{ab}}$ & $9.01 \pm 0.32^{\mathrm{ab}}$ & $11.76 \pm 1.73^{\mathrm{bc}}$ & $20.62 \pm 0.22^{\mathrm{d}}$ & $14.89 \pm 0.25^{\mathrm{c}}$ & $11.32 \pm 0.07^{b}$ \\
\hline C20:0 & $0.38 \pm 0.01^{\mathrm{d}}$ & $0.21 \pm 0.01^{\mathrm{ab}}$ & $0.25 \pm 0.00^{\mathrm{b}}$ & $0.17 \pm 0.01^{\mathrm{a}}$ & $0.25 \pm 0.01^{\mathrm{bc}}$ & $0.30 \pm 0.02^{\mathrm{c}}$ & $0.55 \pm 0.01^{\mathrm{e}}$ & $0.22 \pm 0.01^{\mathrm{ab}}$ & $0.20 \pm 0.00^{\mathrm{a}}$ \\
\hline C20:1n-9 & $0.01 \pm 0.00^{\mathrm{a}}$ & $0.03 \pm 0.02^{\mathrm{ab}}$ & $0.01 \pm 0.00^{\mathrm{a}}$ & $0.05 \pm 0.00^{\mathrm{ab}}$ & $0.03 \pm 0.01^{\mathrm{ab}}$ & $0.03 \pm 0.01^{\mathrm{ab}}$ & $0.03 \pm 0.01^{\mathrm{ab}}$ & $0.07 \pm 0.00^{\mathrm{b}}$ & $0.05 \pm 0.01^{\mathrm{ab}}$ \\
\hline C18:3n-3 & $6.25 \pm 0.27^{\mathrm{c}}$ & $2.80 \pm 0.07^{\mathrm{a}}$ & $3.25 \pm 0.04^{\mathrm{a}}$ & $3.46 \pm 0.13^{\mathrm{a}}$ & $3.65 \pm 0.05^{\mathrm{ab}}$ & $5.51 \pm 1.00^{\mathrm{bc}}$ & $3.22 \pm 0.09^{\mathrm{a}}$ & $19.55 \pm 0.34^{\mathrm{d}}$ & $20.59 \pm 0.49^{\mathrm{d}}$ \\
\hline$C 20: 2 n-6$ & $0.83 \pm 0.10^{\mathrm{ab}}$ & $1.07 \pm 0.05^{\mathrm{bc}}$ & $1.14 \pm 0.04^{\mathrm{c}}$ & $1.00 \pm 0.03^{\mathrm{abc}}$ & $0.93 \pm 0.04^{\mathrm{abc}}$ & $1.15 \pm 0.09^{\mathrm{c}}$ & $1.80 \pm 0.02^{\mathrm{d}}$ & $1.08 \pm 0.05^{\mathrm{bc}}$ & $0.76 \pm 0.01^{\mathrm{a}}$ \\
\hline$C 20: 3 n-6$ & $0.18 \pm 0.02^{\mathrm{a}}$ & $0.10 \pm 0.01^{\mathrm{a}}$ & $0.10 \pm 0.01^{\mathrm{a}}$ & $0.10 \pm 0.01^{\mathrm{a}}$ & $0.11 \pm 0.01^{\mathrm{a}}$ & $0.08 \pm 0.00^{\mathrm{a}}$ & $1.03 \pm 0.06^{\mathrm{b}}$ & $0.11 \pm 0.01^{\mathrm{a}}$ & $0.08 \pm 0.01^{\mathrm{a}}$ \\
\hline C22:1n-9 & $1.13 \pm 0.04^{\mathrm{b}}$ & $0.11 \pm 0.02^{\mathrm{a}}$ & $0.06 \pm 0.01^{\mathrm{a}}$ & $0.06 \pm 0.02^{\mathrm{a}}$ & $0.09 \pm 0.01^{\mathrm{a}}$ & $2.98 \pm 0.07^{b}$ & $0.06 \pm 0.01^{\mathrm{a}}$ & $0.07 \pm 0.00^{\mathrm{a}}$ & $0.03 \pm 0.01^{\mathrm{a}}$ \\
\hline $\mathrm{C} 20: 3 \mathrm{n}-3$ & $1.47 \pm 0.07^{\mathrm{b}}$ & $0.96 \pm 0.05^{\mathrm{a}}$ & $0.88 \pm 0.02^{\mathrm{a}}$ & $0.90 \pm 0.04^{\mathrm{a}}$ & $0.97 \pm 0.02^{\mathrm{a}}$ & $0.99 \pm 0.02^{\mathrm{a}}$ & $0.88 \pm 0.04^{\mathrm{a}}$ & $4.21 \pm 0.11^{\mathrm{d}}$ & $3.79 \pm 0.14^{\mathrm{c}}$ \\
\hline$C 20: 4 n-6$ & $0.17 \pm 0.03^{b}$ & $0.10 \pm 0.01^{\mathrm{ab}}$ & $0.06 \pm 0.02^{\mathrm{a}}$ & $0.08 \pm 0.02^{\mathrm{a}}$ & $0.12 \pm 0.01^{\mathrm{ab}}$ & $0.06 \pm 0.01^{\mathrm{a}}$ & $0.10 \pm 0.01^{\mathrm{ab}}$ & $0.07 \pm 0.00^{\mathrm{a}}$ & $0.05 \pm 0.01^{\mathrm{a}}$ \\
\hline C20:4n-3 & $0.26 \pm 0.04^{\mathrm{bcd}}$ & $0.30 \pm 0.01^{\mathrm{cd}}$ & $0.24 \pm 0.02^{\mathrm{abc}}$ & $0.21 \pm 0.02^{\mathrm{ab}}$ & $0.22 \pm 0.02^{\mathrm{abc}}$ & $0.22 \pm 0.00^{\mathrm{abc}}$ & $0.35 \pm 0.00^{\mathrm{d}}$ & $0.28 \pm 0.02^{\mathrm{bcd}}$ & $0.16 \pm 0.01^{\mathrm{a}}$ \\
\hline $\mathrm{C} 24: 0$ & $2.05 \pm 0.08^{\mathrm{b}}$ & $0.45 \pm 0.01^{\mathrm{a}}$ & $0.50 \pm 0.03^{\mathrm{a}}$ & $0.51 \pm 0.02^{\mathrm{a}}$ & $0.51 \pm 0.01^{\mathrm{a}}$ & $0.53 \pm 0.02^{\mathrm{a}}$ & $0.49 \pm 0.01^{\mathrm{a}}$ & $0.60 \pm 0.01^{\mathrm{a}}$ & $0.55 \pm 0.02^{\mathrm{a}}$ \\
\hline$C 20: 5 n-3$ & $0.79 \pm 0.09^{\mathrm{c}}$ & $0.56 \pm 0.02^{\mathrm{abc}}$ & $0.38 \pm 0.02^{\mathrm{a}}$ & $0.45 \pm 0.05^{\mathrm{ab}}$ & $0.53 \pm 0.06^{\mathrm{abc}}$ & $0.74 \pm 0.11^{\mathrm{c}}$ & $0.44 \pm 0.03^{\mathrm{ab}}$ & $0.69 \pm 0.03^{b c}$ & $0.57 \pm 0.04^{\mathrm{abc}}$ \\
\hline$C 22: 5 n-3$ & $2.38 \pm 0.12^{\mathrm{c}}$ & $0.87 \pm 0.01^{\mathrm{b}}$ & $0.72 \pm 0.02^{\mathrm{ab}}$ & $0.69 \pm 0.02^{\mathrm{ab}}$ & $0.70 \pm 0.04^{\mathrm{ab}}$ & $0.60 \pm 0.04^{\mathrm{a}}$ & $0.77 \pm 0.01^{\mathrm{ab}}$ & $0.73 \pm 0.02^{\mathrm{ab}}$ & $0.69 \pm 0.03^{\mathrm{ab}}$ \\
\hline$C 22: 6 n-3$ & $7.22 \pm 0.13^{b}$ & $2.60 \pm 0.19^{\mathrm{a}}$ & $2.04 \pm 0.01^{\mathrm{a}}$ & $2.22 \pm 0.06^{\mathrm{a}}$ & $2.28 \pm 0.21^{\mathrm{a}}$ & $2.10 \pm 0.06^{\mathrm{a}}$ & $2.22 \pm 0.08^{\mathrm{a}}$ & $2.58 \pm 0.16^{\mathrm{a}}$ & $2.24 \pm 0.09^{\mathrm{a}}$ \\
\hline$\Sigma \mathrm{SFA}^{1}$ & $34.24 \pm 0.60^{\mathrm{b}}$ & $50.67 \pm 0.55^{\mathrm{d}}$ & $37.16 \pm 0.34^{c}$ & $27.27 \pm 0.88^{\mathrm{a}}$ & $26.54 \pm 0.32^{\mathrm{a}}$ & $26.13 \pm 0.71^{\mathrm{a}}$ & $28.28 \pm 0.06^{\mathrm{a}}$ & $26.63 \pm 0.40^{\mathrm{a}}$ & $27.89 \pm 0.59^{\mathrm{a}}$ \\
\hline$\Sigma$ MUFA $^{2}$ & $29.55 \pm 1.52^{\mathrm{a}}$ & $27.80 \pm 0.29^{\mathrm{a}}$ & $39.61 \pm 0.41^{\mathrm{b}}$ & $50.17 \pm 1.08^{\mathrm{cd}}$ & $51.65 \pm 0.56^{\mathrm{d}}$ & $46.64 \pm 1.97^{\mathrm{c}}$ & $37.29 \pm 0.17^{\mathbf{b}}$ & $26.15 \pm 0.18^{\mathrm{a}}$ & $29.20 \pm 0.13^{\mathrm{a}}$ \\
\hline$\Sigma$ PUFA $^{3}$ & $28.74 \pm 1.63^{\mathrm{cd}}$ & $17.17 \pm 0.23^{\mathrm{a}}$ & $20.08 \pm 0.27^{\mathrm{ab}}$ & $19.46 \pm 0.24^{\mathrm{ab}}$ & $18.52 \pm 0.66^{\mathrm{ab}}$ & $23.21 \pm 3.00^{\mathrm{bc}}$ & $31.42 \pm 0.06^{\mathrm{d}}$ & $44.19 \pm 0.43^{\mathrm{e}}$ & $40.27 \pm 0.59^{\mathrm{e}}$ \\
\hline इn-6 PUFA ${ }^{4}$ & $10.37 \pm 0.97^{\mathrm{ab}}$ & $9.07 \pm 0.08^{\mathrm{a}}$ & $12.56 \pm 0.19^{\mathrm{ab}}$ & $11.53 \pm 0.28^{\mathrm{ab}}$ & $10.18 \pm 0.37^{\mathrm{ab}}$ & $13.05 \pm 1.80^{\mathrm{bc}}$ & $23.55 \pm 0.19^{d}$ & $16.15 \pm 0.30^{c}$ & $12.22 \pm 0.06^{\mathrm{ab}}$ \\
\hline इn-3 PUFA ${ }^{5}$ & $18.37 \pm 0.66^{c}$ & $8.09 \pm 0.18^{\mathrm{ab}}$ & $7.51 \pm 0.08^{\mathrm{a}}$ & $7.93 \pm 0.22^{\mathrm{ab}}$ & $8.34 \pm 0.31^{\mathrm{ab}}$ & $10.17 \pm 1.20^{\mathrm{b}}$ & $7.87 \pm 0.20^{\mathrm{ab}}$ & $28.03 \pm 0.20^{\mathrm{d}}$ & $28.05 \pm 0.55^{\mathrm{d}}$ \\
\hline$\Sigma$ LC-PUFA $^{6}$ & $13.29 \pm 0.56^{\mathrm{e}}$ & $6.56 \pm 0.25^{\mathrm{ab}}$ & $5.57 \pm 0.10^{\mathrm{a}}$ & $5.65 \pm 0.14^{\mathrm{a}}$ & $5.86 \pm 0.40^{\mathrm{a}}$ & $5.94 \pm 0.27^{\mathrm{a}}$ & $7.58 \pm 0.14^{\mathrm{bc}}$ & $9.74 \pm 0.22^{\mathrm{d}}$ & $8.36 \pm 0.24^{\mathrm{cd}}$ \\
\hline n-3/n-6 PUFA & $1.79 \pm 0.10^{\mathrm{d}}$ & $0.89 \pm 0.02^{\mathrm{c}}$ & $0.60 \pm 0.00^{\mathrm{b}}$ & $0.69 \pm 0.03^{\mathrm{bc}}$ & $0.82 \pm 0.02^{\mathrm{c}}$ & $0.78 \pm 0.02^{\mathrm{bc}}$ & $0.33 \pm 0.01^{\mathrm{a}}$ & $1.74 \pm 0.03^{\mathrm{d}}$ & $2.30 \pm 0.04^{\mathrm{e}}$ \\
\hline
\end{tabular}


Notes: Values are mean $\pm \mathrm{SE}(\mathrm{n}=3)$. Mean values in the same row with different superscripts are significantly different $(P<0.05)$. ND, no detected.

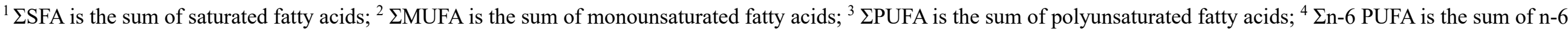
polyunsaturated fatty acids; ${ }^{5} \Sigma$ n-3 PUFA is the sum of n-3 polyunsaturated fatty acids; ${ }^{6} \Sigma$ LC-PUFA is the sum of long-chain polyunsaturated fatty acids.

FO, fish oil; CO, coconut oil; PO, palm oil; OTO, oil-tea camellia oil; OO, olive oil; CNO, canola oil; PNO, peanut oil; LO, linseed oil; PFO, perilla oil. 
Supplementary Table 3. The fatty acid composition of neutral lipids of ventral muscle ( $\%$ total fatty acids).

\begin{tabular}{|c|c|c|c|c|c|c|c|c|c|}
\hline \multirow[t]{2}{*}{ Parameter } & \multicolumn{9}{|c|}{ Dietary treatment } \\
\hline & $\mathrm{FO}$ & $\mathrm{CO}$ & $\mathrm{PO}$ & OTO & $\mathrm{OO}$ & $\mathrm{CNO}$ & PNO & LO & PFO \\
\hline $\mathrm{C} 12: 0$ & $0.03 \pm 0.00^{\mathrm{a}}$ & $12.19 \pm 1.59^{\mathrm{b}}$ & $0.03 \pm 0.01^{\mathrm{a}}$ & $0.04 \pm 0.01^{\mathrm{a}}$ & ND & ND & ND & ND & ND \\
\hline $\mathrm{C} 14: 0$ & $3.03 \pm 0.15^{\mathrm{b}}$ & $11.30 \pm 0.60^{\mathrm{c}}$ & $1.88 \pm 0.12^{\mathrm{a}}$ & $1.29 \pm 0.10^{\mathrm{a}}$ & $1.18 \pm 0.02^{\mathrm{a}}$ & $1.52 \pm 0.07^{\mathrm{a}}$ & $1.25 \pm 0.07^{\mathrm{a}}$ & $1.24 \pm 0.06^{\mathrm{a}}$ & $1.43 \pm 0.03^{\mathrm{a}}$ \\
\hline C16:0 & $\begin{array}{l}24.76 \quad \pm \\
0.39^{\mathrm{b}}\end{array}$ & $26.48 \pm 0.26^{\mathrm{b}}$ & $29.27 \pm 0.20^{c}$ & $20.24 \pm 0.46^{\mathrm{a}}$ & $20.77 \pm 0.07^{\mathrm{a}}$ & $19.32 \pm 0.51^{\mathrm{a}}$ & $20.84 \pm 0.72^{\mathrm{a}}$ & $19.22 \pm 0.63^{\mathrm{a}}$ & $20.03 \pm 0.63^{\mathrm{a}}$ \\
\hline C16:1n-9 & $4.46 \pm 0.22^{c}$ & $3.57 \pm 0.03^{b}$ & $2.45 \pm 0.11^{\mathrm{a}}$ & $2.02 \pm 0.14^{\mathrm{a}}$ & $2.17 \pm 0.04^{\mathrm{a}}$ & $2.22 \pm 0.06^{\mathrm{a}}$ & $2.08 \pm 0.14^{\mathrm{a}}$ & $1.94 \pm 0.07^{\mathrm{a}}$ & $2.36 \pm 0.05^{\mathrm{a}}$ \\
\hline C18:0 & $4.68 \pm 0.45^{\mathrm{c}}$ & $3.85 \pm 0.07^{\mathrm{abc}}$ & $4.41 \pm 0.24^{\mathrm{bc}}$ & $3.46 \pm 0.24^{\mathrm{abc}}$ & $4.11 \pm 0.05^{\mathrm{abc}}$ & $3.08 \pm 0.15^{\mathrm{a}}$ & $4.10 \pm 0.21^{\mathrm{abc}}$ & $3.99 \pm 0.18^{\mathrm{abc}}$ & $3.21 \pm 0.39^{\mathrm{ab}}$ \\
\hline C18:1n-9 & $25.86 \pm 0.72^{\mathrm{a}}$ & $24.23 \pm 0.48^{\mathrm{a}}$ & $38.10 \pm 0.59^{b}$ & $50.26 \pm 0.78^{c}$ & $52.82 \pm 0.34^{\mathrm{c}}$ & $38.79 \pm 0.33^{b}$ & $35.60 \pm 1.21^{\mathrm{b}}$ & $25.70 \pm 1.14^{\mathrm{a}}$ & $24.94 \pm 1.09^{\mathrm{a}}$ \\
\hline C18:2n-6 & $8.43 \pm 0.26^{\mathrm{a}}$ & $8.23 \pm 0.17^{\mathrm{a}}$ & $11.81 \pm 0.26^{\mathrm{b}}$ & $10.62 \pm 0.24^{\mathrm{ab}}$ & $8.27 \pm 0.29^{\mathrm{a}}$ & $14.40 \pm 0.65^{c}$ & $21.53 \pm 0.81^{\mathrm{d}}$ & $14.87 \pm 0.73^{c}$ & $\begin{array}{l}12.78 \\
0.68^{\mathrm{bc}}\end{array}$ \\
\hline C20:0 & $0.40 \pm 0.02^{\mathrm{c}}$ & $0.22 \pm 0.02^{\mathrm{ab}}$ & $0.27 \pm 0.01^{\mathrm{b}}$ & $0.18 \pm 0.01^{\mathrm{ab}}$ & $0.25 \pm 0.01^{\mathrm{ab}}$ & $0.38 \pm 0.01^{\mathrm{c}}$ & $0.59 \pm 0.04^{\mathrm{d}}$ & $0.22 \pm 0.01^{\mathrm{ab}}$ & $0.16 \pm 0.02^{\mathrm{a}}$ \\
\hline C20:1n-9 & $0.05 \pm 0.00^{\mathrm{ab}}$ & $0.08 \pm 0.01^{\mathrm{b}}$ & $0.08 \pm 0.00^{\mathrm{b}}$ & $0.06 \pm 0.02^{\mathrm{ab}}$ & $0.06 \pm 0.01^{\mathrm{ab}}$ & $0.06 \pm 0.02^{\mathrm{ab}}$ & $0.03 \pm 0.01^{\mathrm{a}}$ & $0.06 \pm 0.00^{\mathrm{ab}}$ & $0.08 \pm 0.01^{\mathrm{ab}}$ \\
\hline C18:3n-3 & $5.28 \pm 0.04^{\mathrm{ab}}$ & $2.45 \pm 0.19^{\mathrm{a}}$ & $3.09 \pm 0.08^{\mathrm{a}}$ & $3.41 \pm 0.14^{\mathrm{a}}$ & $3.45 \pm 0.03^{\mathrm{a}}$ & $7.17 \pm 0.16^{b}$ & $3.19 \pm 0.06^{\mathrm{a}}$ & $20.25 \pm 0.97^{\mathrm{c}}$ & $24.39 \pm 1.49^{\mathrm{d}}$ \\
\hline$C 20: 2 n-6$ & $0.70 \pm 0.03^{\mathrm{a}}$ & $1.01 \pm 0.11^{\mathrm{abc}}$ & $1.26 \pm 0.06^{\mathrm{bc}}$ & $1.05 \pm 0.02^{\mathrm{abc}}$ & $0.81 \pm 0.04^{\mathrm{a}}$ & $1.42 \pm 0.12^{\mathrm{c}}$ & $1.95 \pm 0.18^{\mathrm{d}}$ & $1.10 \pm 0.04^{\mathrm{abc}}$ & $0.83 \pm 0.03^{\mathrm{ab}}$ \\
\hline$C 20: 3 n-6$ & $0.12 \pm 0.00^{\mathrm{a}}$ & $0.13 \pm 0.01^{\mathrm{a}}$ & $0.13 \pm 0.00^{\mathrm{a}}$ & $0.12 \pm 0.00^{\mathrm{a}}$ & $0.10 \pm 0.01^{\mathrm{a}}$ & $0.14 \pm 0.02^{\mathrm{a}}$ & $1.03 \pm 0.12^{\mathrm{b}}$ & $0.15 \pm 0.01^{\mathrm{a}}$ & $0.19 \pm 0.05^{\mathrm{a}}$ \\
\hline C22:1n-9 & $1.18 \pm 0.06^{\mathrm{a}}$ & ND & ND & ND & ND & ND & $3.74 \pm 0.09^{b}$ & ND & ND \\
\hline$C 20: 3 n-3$ & $1.41 \pm 0.05^{b}$ & $0.76 \pm 0.14^{\mathrm{a}}$ & $0.91 \pm 0.10^{\mathrm{ab}}$ & $0.89 \pm 0.06^{\mathrm{ab}}$ & $1.01 \pm 0.09^{\mathrm{ab}}$ & $1.25 \pm 0.03^{\mathrm{ab}}$ & $0.86 \pm 0.03^{\mathrm{ab}}$ & $4.17 \pm 0.24^{\mathrm{c}}$ & $4.03 \pm 0.20^{c}$ \\
\hline$C 20: 4 n-6$ & $0.10 \pm 0.01$ & $0.05 \pm 0.02$ & $0.06 \pm 0.00$ & $0.04 \pm 0.01$ & $0.06 \pm 0.01$ & $0.06 \pm 0.01$ & $0.08 \pm 0.02$ & $0.07 \pm 0.00$ & $0.08 \pm 0.02$ \\
\hline$C 20: 4 n-3$ & $0.18 \pm 0.03^{\mathrm{ab}}$ & $0.22 \pm 0.05^{\mathrm{ab}}$ & $0.18 \pm 0.02^{\mathrm{ab}}$ & $0.17 \pm 0.02^{\mathrm{ab}}$ & $0.10 \pm 0.02^{\mathrm{a}}$ & $0.23 \pm 0.02^{\mathrm{ab}}$ & $0.41 \pm 0.05^{\mathrm{c}}$ & $0.26 \pm 0.00^{\mathrm{b}}$ & $0.13 \pm 0.02^{\mathrm{ab}}$ \\
\hline $\mathrm{C} 24: 0$ & $2.25 \pm 0.07^{b}$ & $0.43 \pm 0.00^{\mathrm{a}}$ & $0.45 \pm 0.01^{\mathrm{a}}$ & $0.46 \pm 0.01^{\mathrm{a}}$ & $0.44 \pm 0.02^{\mathrm{a}}$ & $0.51 \pm 0.01^{\mathrm{a}}$ & $0.49 \pm 0.04^{\mathrm{a}}$ & $0.56 \pm 0.04^{\mathrm{a}}$ & $0.58 \pm 0.01^{\mathrm{a}}$ \\
\hline$C 20: 5 n-3$ & $0.71 \pm 0.04^{b}$ & $0.40 \pm 0.11^{\mathrm{a}}$ & $0.42 \pm 0.02^{\mathrm{a}}$ & $0.44 \pm 0.05^{\mathrm{ab}}$ & $0.36 \pm 0.03^{\mathrm{a}}$ & $1.07 \pm 0.05^{\mathrm{c}}$ & $0.37 \pm 0.06^{\mathrm{a}}$ & $0.49 \pm 0.02^{\mathrm{ab}}$ & $0.31 \pm 0.08^{\mathrm{a}}$ \\
\hline$C 22: 5 n-3$ & $2.36 \pm 0.06^{\mathrm{b}}$ & $0.61 \pm 0.22^{\mathrm{a}}$ & $0.78 \pm 0.01^{\mathrm{a}}$ & $0.70 \pm 0.03^{\mathrm{a}}$ & $0.65 \pm 0.02^{\mathrm{a}}$ & $0.64 \pm 0.06^{\mathrm{a}}$ & $0.77 \pm 0.06^{\mathrm{a}}$ & $0.77 \pm 0.01^{\mathrm{a}}$ & $0.68 \pm 0.00^{\mathrm{a}}$ \\
\hline
\end{tabular}




\begin{tabular}{|c|c|c|c|c|c|c|c|c|c|}
\hline$C 22: 6 n-3$ & $7.30 \pm 0.14^{\mathrm{c}}$ & $2.38 \pm 0.09^{b}$ & $2.14 \pm 0.08^{\mathrm{ab}}$ & $2.01 \pm 0.02^{\mathrm{ab}}$ & $1.84 \pm 0.05^{\mathrm{a}}$ & $2.09 \pm 0.13^{\mathrm{ab}}$ & $2.10 \pm 0.13^{\mathrm{ab}}$ & $2.22 \pm 0.11^{\mathrm{ab}}$ & $2.12 \pm 0.09^{\mathrm{ab}}$ \\
\hline$\Sigma \mathrm{SFA}^{1}$ & $\begin{array}{l}35.14 \\
0.35^{\mathrm{b}}\end{array}$ & $54.45 \pm 1.90^{\mathrm{a}}$ & $36.59 \pm 0.13^{b}$ & $25.66 \pm 0.34^{\mathrm{a}}$ & $26.75 \pm 0.06^{\mathrm{a}}$ & $24.80 \pm 0.64^{\mathrm{a}}$ & $27.26 \pm 0.68^{a}$ & $25.24 \pm 0.74^{\mathrm{a}}$ & $25.40 \pm 0.99^{\mathrm{a}}$ \\
\hline$\Sigma \mathrm{MUFA}^{2}$ & $\begin{array}{l}31.55 \\
0.52^{\mathrm{b}}\end{array}$ & $27.88 \pm 0.50^{\mathrm{ab}}$ & $40.63 \pm 0.50^{c}$ & $52.33 \pm 0.63^{\mathrm{e}}$ & $55.06 \pm 0.34^{\mathrm{e}}$ & $44.80 \pm 0.32^{\mathrm{d}}$ & $37.71 \pm 1.24^{\mathrm{c}}$ & $27.69 \pm 1.16^{\mathrm{a}}$ & $27.39 \pm 1.03^{\mathrm{a}}$ \\
\hline$\Sigma \mathrm{PUFA}^{3}$ & $\begin{array}{l}26.60 \\
0.57^{\text {bc }}\end{array}$ & $16.25 \pm 0.87^{\mathrm{a}}$ & $20.77 \pm 0.41^{\mathrm{ab}}$ & $19.44 \pm 0.22^{\mathrm{a}}$ & $16.64 \pm 0.37^{\mathrm{a}}$ & $28.47 \pm 1.03^{c}$ & $32.29 \pm 1.50^{\mathrm{c}}$ & $44.36 \pm 1.82^{\mathrm{d}}$ & $45.55 \pm 2.45^{\mathrm{d}}$ \\
\hline$\Sigma$ n-6 PUFA ${ }^{4}$ & $9.35 \pm 0.30^{\mathrm{a}}$ & $9.42 \pm 0.24^{\mathrm{a}}$ & $13.26 \pm 0.32^{\mathrm{bc}}$ & $11.82 \pm 0.25^{\mathrm{ab}}$ & $9.23 \pm 0.32^{\mathrm{a}}$ & $16.03 \pm 0.79^{c}$ & $24.59 \pm 1.12^{\mathrm{d}}$ & $16.19 \pm 0.76^{\mathrm{c}}$ & $\begin{array}{l}13.88 \\
0.77^{\mathrm{bc}}\end{array}$ \\
\hline$\Sigma$ n-3 PUFA ${ }^{5}$ & $17.24 \pm 0.30^{\mathrm{c}}$ & $6.83 \pm 0.67^{\mathrm{a}}$ & $7.52 \pm 0.16^{\mathrm{a}}$ & $7.62 \pm 0.19^{a}$ & $7.41 \pm 0.08^{\mathrm{a}}$ & $12.44 \pm 0.32^{b}$ & $7.70 \pm 0.38^{a}$ & $28.17 \pm 1.29^{d}$ & $31.66 \pm 1.68^{d}$ \\
\hline$\Sigma$ LC-PUFA $^{6}$ & $12.89 \pm 0.30^{f}$ & $5.56 \pm 0.58^{\mathrm{ab}}$ & $5.87 \pm 0.18^{\mathrm{abc}}$ & $5.41 \pm 0.07^{\mathrm{ab}}$ & $4.92 \pm 0.09^{\mathrm{a}}$ & $6.90 \pm 0.35^{\mathrm{bcd}}$ & $7.57 \pm 0.63^{\text {cde }}$ & $9.24 \pm 0.39^{\mathrm{e}}$ & $8.38 \pm 0.31^{\mathrm{de}}$ \\
\hline n-3/n-6 PUFA & $1.85 \pm 0.03^{\mathrm{d}}$ & $0.72 \pm 0.06^{b c}$ & $0.57 \pm 0.01^{b}$ & $0.65 \pm 0.02^{b c}$ & $0.80 \pm 0.03^{c}$ & $0.78 \pm 0.03^{\mathrm{c}}$ & $0.31 \pm 0.00^{\mathrm{a}}$ & $1.74 \pm 0.07^{\mathrm{d}}$ & $2.28 \pm 0.01^{\mathrm{e}}$ \\
\hline
\end{tabular}

Notes: Values are mean $\pm \mathrm{SE}(\mathrm{n}=3)$. Mean values in the same row with different superscripts are significantly different $(P<0.05)$. ND, no detected.

${ }^{1} \Sigma$ SFA is the sum of saturated fatty acids; ${ }^{2} \Sigma$ MUFA is the sum of monounsaturated fatty acids; ${ }^{3} \Sigma$ PUFA is the sum of polyunsaturated fatty acids; ${ }^{4} \Sigma$ n- 6 PUFA is the sum of n-6 polyunsaturated fatty acids; ${ }^{5} \Sigma$ n-3 PUFA is the sum of n-3 polyunsaturated fatty acids; ${ }^{6} \Sigma$ LC-PUFA is the sum of long-chain polyunsaturated fatty acids. FO, fish oil; CO, coconut oil; PO, palm oil; OTO, oil-tea camellia oil; OO, olive oil; CNO, canola oil; PNO, peanut oil; LO, linseed oil; PFO, perilla oil. 
Supplementary Table 4. The fatty acid composition of polar lipids of liver ( $\%$ total fatty acids).

\begin{tabular}{|c|c|c|c|c|c|c|c|c|c|}
\hline \multirow[t]{2}{*}{ Parameter } & \multicolumn{9}{|c|}{ Dietary treatment } \\
\hline & $\mathrm{FO}$ & $\mathrm{CO}$ & $\mathrm{PO}$ & OTO & $\mathrm{OO}$ & $\mathrm{CNO}$ & PNO & $\mathrm{LO}$ & PFO \\
\hline C12:0 & ND & ND & ND & ND & ND & ND & ND & ND & ND \\
\hline $\mathrm{C} 14: 0$ & $0.58 \pm 0.03^{b}$ & $1.07 \pm 0.06^{\mathrm{c}}$ & $0.32 \pm 0.10^{\mathrm{ab}}$ & $0.26 \pm 0.02^{\mathrm{a}}$ & $0.40 \pm 0.09^{\mathrm{ab}}$ & $0.55 \pm 0.05^{\mathrm{ab}}$ & $0.50 \pm 0.03^{\mathrm{ab}}$ & $0.25 \pm 0.08^{\mathrm{a}}$ & $0.28 \pm 0.06^{\mathrm{ab}}$ \\
\hline C16:0 & $\begin{array}{l}23.59 \\
0.33^{\mathrm{b}}\end{array}$ & $22.89 \pm 0.59^{\mathrm{ab}}$ & $19.74 \pm 1.25^{\mathrm{a}}$ & $20.07 \pm 0.30^{\mathrm{ab}}$ & $19.36 \pm 0.53^{\mathrm{a}}$ & $19.57 \pm 0.10^{\mathrm{a}}$ & $\begin{array}{l}21.10 \\
0.91^{\mathrm{ab}}\end{array}$ & $22.89 \pm 1.20^{\mathrm{ab}}$ & $\begin{array}{l}21.65 \\
0.57^{\mathrm{ab}}\end{array}$ \\
\hline $\mathrm{C} 16: 1^{1}$ & $1.08 \pm 0.04$ & $0.88 \pm 0.09$ & $0.89 \pm 0.18$ & $0.61 \pm 0.02$ & $0.85 \pm 0.15$ & $0.98 \pm 0.04$ & $1.07 \pm 0.08$ & $0.59 \pm 0.12$ & $0.75 \pm 0.06$ \\
\hline C18:0 & $9.08 \pm 0.26^{\mathrm{cd}}$ & $10.84 \pm 0.17^{\mathrm{ef}}$ & $9.55 \pm 0.73^{\mathrm{de}}$ & $8.70 \pm 0.28^{\mathrm{bcd}}$ & $7.47 \pm 0.15^{\mathrm{abc}}$ & $6.79 \pm 0.17^{\mathrm{a}}$ & $7.35 \pm 0.22^{\mathrm{ab}}$ & $11.85 \pm 0.44^{\mathrm{f}}$ & $9.74 \pm 0.15^{\mathrm{de}}$ \\
\hline $\mathrm{C} 18: 1^{2}$ & $14.73 \pm 0.21^{\mathrm{a}}$ & $12.13 \pm 0.72^{\mathrm{a}}$ & $17.69 \pm 2.02^{\mathrm{ab}}$ & $23.78 \pm 0.32^{\mathrm{bc}}$ & $26.15 \pm 3.75^{b c}$ & $26.84 \pm 0.47^{c}$ & $\begin{array}{l}24.75 \\
0.80^{\mathrm{bc}}\end{array}$ & $17.93 \pm 2.42^{\mathrm{ab}}$ & $\begin{array}{l}19.23 \\
1.03^{\mathrm{abc}}\end{array}$ \\
\hline$C 18: 2 n-6$ & $5.19 \pm 0.25^{\mathrm{a}}$ & $8.64 \pm 0.21^{\mathrm{ab}}$ & $11.52 \pm 1.72^{\mathrm{ab}}$ & $7.81 \pm 0.10^{\mathrm{ab}}$ & $9.76 \pm 2.54^{\mathrm{ab}}$ & $10.21 \pm 1.17^{\mathrm{ab}}$ & $13.02 \pm 1.91^{\mathrm{b}}$ & $9.93 \pm 0.54^{\mathrm{ab}}$ & $7.38 \pm 0.20^{\mathrm{ab}}$ \\
\hline C20:0 & $\begin{array}{l}0.19 \quad \pm \\
0.02^{\text {bcd }}\end{array}$ & $0.13 \pm 0.01^{\mathrm{ab}}$ & $0.16 \pm 0.01^{\mathrm{abc}}$ & $0.12 \pm 0.01^{\mathrm{a}}$ & $0.19 \pm 0.02^{\mathrm{bcd}}$ & $0.20 \pm 0.01^{\mathrm{cd}}$ & $0.24 \pm 0.02^{\mathrm{d}}$ & $0.21 \pm 0.01^{\mathrm{cd}}$ & $0.20 \pm 0.01^{\mathrm{bcd}}$ \\
\hline $\mathrm{C} 20: 1 \mathrm{n}-9$ & $0.20 \pm 0.00$ & $0.10 \pm 0.01$ & $0.13 \pm 0.01$ & $0.10 \pm 0.02$ & $0.08 \pm 0.01$ & $0.08 \pm 0.01$ & $0.37 \pm 0.27$ & $0.08 \pm 0.01$ & $0.09 \pm 0.00$ \\
\hline$C 18: 3 n-3$ & $1.97 \pm 0.03^{\mathrm{ab}}$ & $1.63 \pm 0.02^{\mathrm{a}}$ & $2.13 \pm 0.25^{\mathrm{ab}}$ & $2.90 \pm 0.05^{b}$ & $2.90 \pm 0.41^{b}$ & $4.16 \pm 0.06^{\mathrm{c}}$ & $2.68 \pm 0.19^{\mathrm{ab}}$ & $7.80 \pm 0.15^{d}$ & $7.39 \pm 0.36^{\mathrm{d}}$ \\
\hline$C 20: 2 n-6$ & $1.43 \pm 0.03^{\mathrm{a}}$ & $2.26 \pm 0.13^{\mathrm{abc}}$ & $2.65 \pm 0.06^{\mathrm{bc}}$ & $2.18 \pm 0.03^{\mathrm{abc}}$ & $2.52 \pm 0.31^{\mathrm{bc}}$ & $2.86 \pm 0.23^{\mathrm{c}}$ & $3.75 \pm 0.26^{\mathrm{d}}$ & $1.95 \pm 0.18^{\mathrm{ab}}$ & $1.76 \pm 0.15^{\mathrm{ab}}$ \\
\hline$C 20: 3 n-6$ & $0.35 \pm 0.25$ & $0.21 \pm 0.01$ & $0.27 \pm 0.03$ & $0.17 \pm 0.01$ & $0.21 \pm 0.04$ & $0.15 \pm 0.02$ & $0.19 \pm 0.01$ & $0.07 \pm 0.00$ & $0.05 \pm 0.01$ \\
\hline C22:1n-9 & ND & ND & $\mathrm{ND}$ & ND & ND & ND & ND & ND & ND \\
\hline$C 20: 3 n-3$ & $0.85 \pm 0.03^{\mathrm{a}}$ & $0.48 \pm 0.03^{\mathrm{a}}$ & $0.48 \pm 0.06^{\mathrm{a}}$ & $0.46 \pm 0.01^{\mathrm{a}}$ & $0.56 \pm 0.07^{\mathrm{a}}$ & $1.60 \pm 0.10^{\mathrm{b}}$ & $0.61 \pm 0.01^{\mathrm{a}}$ & $4.29 \pm 0.27^{\mathrm{c}}$ & $4.41 \pm 0.04^{\mathrm{c}}$ \\
\hline$C 20: 4 n-6$ & $2.83 \pm 0.08^{\mathrm{cd}}$ & $2.38 \pm 0.16^{\mathrm{d}}$ & $1.89 \pm 0.11^{\mathrm{bc}}$ & $1.38 \pm 0.05^{\mathrm{ab}}$ & $1.40 \pm 0.16^{\mathrm{ab}}$ & $1.24 \pm 0.01^{\mathrm{ab}}$ & $0.96 \pm 0.09^{a}$ & $1.62 \pm 0.28^{\mathrm{ab}}$ & $1.40 \pm 0.08^{\mathrm{ab}}$ \\
\hline$C 20: 4 n-3$ & $0.37 \pm 0.01^{\mathrm{c}}$ & $0.26 \pm 0.01^{b c}$ & $0.18 \pm 0.04^{\mathrm{ab}}$ & $0.11 \pm 0.01^{\mathrm{a}}$ & $0.12 \pm 0.02^{\mathrm{ab}}$ & $0.11 \pm 0.01^{\mathrm{a}}$ & $0.22 \pm 0.03^{\mathrm{ab}}$ & $0.13 \pm 0.06^{\mathrm{ab}}$ & $0.21 \pm 0.01^{\mathrm{ab}}$ \\
\hline $\mathrm{C} 24: 0$ & $1.38 \pm 0.03^{b c}$ & $1.41 \pm 0.04^{\mathrm{c}}$ & $1.39 \pm 0.32^{\mathrm{c}}$ & $0.99 \pm 0.04^{\mathrm{abc}}$ & $0.72 \pm 0.07^{\mathrm{a}}$ & $0.77 \pm 0.05^{\mathrm{a}}$ & $0.45 \pm 0.03^{\mathrm{a}}$ & $0.77 \pm 0.13^{\mathrm{ab}}$ & $0.83 \pm 0.09^{\mathrm{abc}}$ \\
\hline$C 20: 5 n-3$ & $0.56 \pm 0.04^{\mathrm{e}}$ & $0.48 \pm 0.00^{\mathrm{de}}$ & $0.48 \pm 0.04^{\mathrm{de}}$ & $0.39 \pm 0.02^{\mathrm{bcd}}$ & $0.43 \pm 0.04^{\mathrm{de}}$ & $0.33 \pm 0.03^{\mathrm{abc}}$ & $0.33 \pm 0.01^{\mathrm{abc}}$ & $0.22 \pm 0.02^{\mathrm{a}}$ & $0.29 \pm 0.02^{\mathrm{ab}}$ \\
\hline
\end{tabular}




\begin{tabular}{|c|c|c|c|c|c|c|c|c|c|}
\hline$C 22: 5 n-3$ & $1.68 \pm 0.01^{\mathrm{f}}$ & $1.64 \pm 0.08^{\mathrm{ef}}$ & $1.35 \pm 0.18^{\mathrm{def}}$ & $1.20 \pm 0.01^{\mathrm{cde}}$ & $0.91 \pm 0.07^{\mathrm{bcd}}$ & $0.80 \pm 0.05^{b c}$ & $0.66 \pm 0.00^{\mathrm{ab}}$ & $0.33 \pm 0.19^{\mathrm{a}}$ & $0.57 \pm 0.05^{\mathrm{ab}}$ \\
\hline$C 22: 6 n-3$ & $33.14 \pm 0.58^{c}$ & $31.26 \pm 0.66^{\mathrm{c}}$ & $26.96 \pm 2.44^{b c}$ & $27.00 \pm 0.52^{b c}$ & $23.84 \pm 2.09^{\mathrm{ab}}$ & $20.56 \pm 1.57^{\mathrm{ab}}$ & $\begin{array}{l}20.17 \\
0.43^{\mathrm{ab}}\end{array}$ & $18.67 \pm 1.64^{\mathrm{a}}$ & $\begin{array}{l}22.98 \\
1.70^{\mathrm{ab}}\end{array}$ \\
\hline$\Sigma \mathrm{SFA}^{3}$ & $\begin{array}{l}34.83 \\
0.34^{\mathrm{d}}\end{array}$ & $36.35 \pm 0.40^{\mathrm{cd}}$ & $\begin{array}{l}31.17 \\
1.58^{\mathrm{abc}}\end{array}$ & $30.14 \pm 0.36^{\mathrm{ab}}$ & $28.14 \pm 0.72^{\mathrm{a}}$ & $27.89 \pm 0.05^{\mathrm{a}}$ & $\begin{array}{l}29.65 \\
0.68^{\mathrm{ab}}\end{array}$ & $35.97 \pm 1.00^{\mathrm{d}}$ & $\begin{array}{l}32.70 \\
0.67^{\text {bcd }}\end{array}$ \\
\hline$\Sigma \mathrm{MUFA}^{4}$ & $\begin{array}{l}16.01 \\
0.24^{\mathrm{ab}}\end{array}$ & $13.12 \pm 0.63^{\mathrm{a}}$ & $\begin{array}{l}18.71 \\
2.20^{\mathrm{abc}}\end{array}$ & $\begin{array}{l}24.49 \\
0.34^{\text {bcd }}\end{array}$ & $27.08 \pm 3.90^{\mathrm{cd}}$ & $27.90 \pm 0.47^{\mathrm{d}}$ & $\begin{array}{l}26.19 \\
0.61^{\mathrm{cd}}\end{array}$ & $\begin{array}{l}18.59 \\
2.54^{\mathrm{abc}}\end{array}$ & $\begin{array}{l}20.07 \\
1.09^{\text {abcd }}\end{array}$ \\
\hline$\Sigma \mathrm{PUFA}^{5}$ & $48.37 \pm 0.97$ & $49.24 \pm 1.09$ & $47.90 \pm 1.80$ & $43.60 \pm 0.62$ & $42.65 \pm 4.26$ & $42.02 \pm 0.60$ & $42.58 \pm 1.66$ & $45.01 \pm 3.18$ & $46.44 \pm 1.81$ \\
\hline$\Sigma \mathrm{n}-6 \mathrm{PUFA}^{6}$ & $9.79 \pm 0.50^{\mathrm{a}}$ & $13.49 \pm 0.48^{\mathrm{ab}}$ & $16.33 \pm 1.69^{\mathrm{ab}}$ & $11.54 \pm 0.18^{\mathrm{ab}}$ & $13.90 \pm 2.96^{\mathrm{ab}}$ & $14.46 \pm 1.38^{\mathrm{ab}}$ & $17.92 \pm 2.26^{\mathrm{b}}$ & $13.58 \pm 0.92^{\mathrm{ab}}$ & $\begin{array}{l}10.60 \\
0.42^{\mathrm{ab}}\end{array}$ \\
\hline$\Sigma \mathrm{n}-3 \mathrm{PUFA}^{7}$ & $38.58 \pm 0.54^{\mathrm{c}}$ & $35.75 \pm 0.61^{\mathrm{bc}}$ & $\begin{array}{l}31.57 \\
2.66^{\mathrm{abc}}\end{array}$ & $\begin{array}{l}32.05 \\
0.50^{\mathrm{abc}}\end{array}$ & $28.75 \pm 2.04^{\mathrm{ab}}$ & $27.56 \pm 1.48^{\mathrm{a}}$ & $24.66 \pm 0.61^{\mathrm{a}}$ & $\begin{array}{l}31.43 \\
2.27^{\mathrm{abc}}\end{array}$ & $\begin{array}{l}35.84 \\
1.41^{\mathrm{bc}}\end{array}$ \\
\hline$\Sigma \mathrm{HUFA}^{8}$ & $41.21 \pm 0.72^{c}$ & $38.96 \pm 0.91^{\mathrm{bc}}$ & $\begin{array}{l}34.25 \\
2.62^{\mathrm{abc}}\end{array}$ & $\begin{array}{l}32.90 \\
0.59^{\mathrm{abc}}\end{array}$ & $29.99 \pm 2.60^{\mathrm{a}}$ & $27.65 \pm 1.41^{\mathrm{a}}$ & $26.89 \pm 0.09^{\mathrm{a}}$ & $27.28 \pm 2.57^{\mathrm{a}}$ & $\begin{array}{l}31.67 \\
1.98^{\mathrm{ab}}\end{array}$ \\
\hline$n-3 / n-6$ & $3.96 \pm 0.17^{\mathrm{d}}$ & $2.65 \pm 0.05^{b c}$ & $2.00 \pm 0.35^{\mathrm{ab}}$ & $2.78 \pm 0.04^{b c}$ & $2.21 \pm 0.36^{\mathrm{ab}}$ & $1.96 \pm 0.27^{\mathrm{ab}}$ & $1.43 \pm 0.19^{a}$ & $2.31 \pm 0.03^{\mathrm{ab}}$ & $3.38 \pm 0.05^{\mathrm{cd}}$ \\
\hline
\end{tabular}

Notes: Values are mean $\pm \mathrm{SE}(\mathrm{n}=3)$. Mean values in the same row with different superscripts are significantly different $(P<0.05)$. ND, no detected.

${ }^{1} \Sigma$ SFA is the sum of saturated fatty acids; ${ }^{2} \Sigma$ MUFA is the sum of monounsaturated fatty acids; ${ }^{3} \Sigma$ PUFA is the sum of polyunsaturated fatty acids; ${ }^{4} \Sigma \mathrm{n}-6$ PUFA is the sum of n-6 polyunsaturated fatty acids; ${ }^{5} \Sigma \mathrm{n}-3$ PUFA is the sum of n-3 polyunsaturated fatty acids; ${ }^{6} \Sigma$ LC-PUFA is the sum of long-chain polyunsaturated fatty acids. FO, fish oil; CO, coconut oil; PO, palm oil; OTO, oil-tea camellia oil; OO, olive oil; CNO, canola oil; PNO, peanut oil; LO, linseed oil; PFO, perilla oil. 
Supplementary Table 5. The fatty acid composition of polar lipids of dorsal muscle ( $\%$ total fatty acids).

\begin{tabular}{|c|c|c|c|c|c|c|c|c|c|}
\hline \multirow[t]{2}{*}{ Parameter } & \multicolumn{9}{|c|}{ Dietary treatment } \\
\hline & $\mathrm{FO}$ & $\mathrm{CO}$ & $\mathrm{PO}$ & OTO & $\mathrm{OO}$ & $\mathrm{CNO}$ & PNO & $\mathrm{LO}$ & PFO \\
\hline $\mathrm{C} 12: 0$ & ND & ND & ND & ND & ND & ND & ND & ND & ND \\
\hline $\mathrm{C} 14: 0$ & $0.55 \pm 0.15^{\mathrm{a}}$ & $1.60 \pm 0.23^{b}$ & ND & ND & ND & ND & ND & ND & ND \\
\hline C16:0 & $\begin{array}{l}19.09 \\
0.40^{\mathrm{ab}}\end{array} \quad \pm$ & $20.65 \pm 1.83^{\mathrm{ab}}$ & $21.22 \pm 0.88^{\mathrm{b}}$ & $16.62 \pm 1.07^{\mathrm{ab}}$ & $16.55 \pm 0.59^{\mathrm{ab}}$ & $16.39 \pm 0.36^{\mathrm{ab}}$ & $15.29 \pm 1.43^{\mathrm{a}}$ & $18.33 \pm 0.87^{\mathrm{ab}}$ & $\begin{array}{l}18.87 \\
1.65^{\mathrm{ab}}\end{array}$ \\
\hline $\mathrm{C} 16: 1^{1}$ & $1.11 \pm 0.12^{\mathrm{ab}}$ & $1.73 \pm 0.27^{\mathrm{b}}$ & $1.15 \pm 0.33^{\mathrm{ab}}$ & $0.49 \pm 0.06^{\mathrm{a}}$ & $0.81 \pm 0.11^{\mathrm{a}}$ & $0.48 \pm 0.03^{\mathrm{a}}$ & $0.74 \pm 0.10^{\mathrm{a}}$ & $0.58 \pm 0.05^{\mathrm{a}}$ & $0.68 \pm 0.07^{\mathrm{a}}$ \\
\hline C18:0 & $13.13 \pm 0.90$ & $12.30 \pm 0.50$ & $11.55 \pm 0.66$ & $11.60 \pm 0.59$ & $10.50 \pm 0.48$ & $10.98 \pm 0.20$ & $11.96 \pm 0.47$ & $12.67 \pm 0.36$ & $12.15 \pm 1.37$ \\
\hline $\mathrm{C} 18: 1^{2}$ & $17.01 \pm 1.05^{\mathrm{a}}$ & $20.44 \pm 0.08^{\mathrm{ab}}$ & $25.85 \pm 1.01^{\mathrm{cd}}$ & $31.41 \pm 0.40^{\mathrm{e}}$ & $33.55 \pm 0.94^{\mathrm{e}}$ & $30.04 \pm 1.59^{\mathrm{de}}$ & $\begin{array}{l}23.50 \\
0.24^{\mathrm{bc}}\end{array}$ & $17.71 \pm 0.76^{\mathrm{a}}$ & $\begin{array}{l}19.31 \\
1.04^{\mathrm{ab}}\end{array}$ \\
\hline$C 18: 2 n-6$ & $7.97 \pm 0.31^{\mathrm{a}}$ & $13.35 \pm 0.66^{\mathrm{b}}$ & $13.63 \pm 0.32^{\mathrm{b}}$ & $12.31 \pm 0.61^{\mathrm{b}}$ & $11.66 \pm 0.39^{\mathrm{b}}$ & $14.13 \pm 0.62^{b}$ & $20.07 \pm 0.24^{\mathrm{c}}$ & $13.79 \pm 0.47^{b}$ & $12.67 \pm 0.90^{\mathrm{b}}$ \\
\hline C20:0 & $0.30 \pm 0.02^{\mathrm{ab}}$ & $0.28 \pm 0.03^{\mathrm{ab}}$ & $0.24 \pm 0.02^{\mathrm{a}}$ & $0.23 \pm 0.02^{\mathrm{a}}$ & $0.27 \pm 0.02^{\mathrm{a}}$ & $0.20 \pm 0.01^{\mathrm{a}}$ & $0.43 \pm 0.07^{\mathrm{b}}$ & $0.25 \pm 0.00^{\mathrm{a}}$ & $0.23 \pm 0.02^{\mathrm{a}}$ \\
\hline C20:1n-9 & $0.28 \pm 0.01^{\mathrm{b}}$ & $0.10 \pm 0.00^{\mathrm{a}}$ & $0.10 \pm 0.02^{\mathrm{a}}$ & $0.16 \pm 0.04^{\mathrm{a}}$ & $0.12 \pm 0.02^{\mathrm{a}}$ & $0.13 \pm 0.01^{\mathrm{a}}$ & $0.14 \pm 0.03^{\mathrm{a}}$ & $0.14 \pm 0.02^{\mathrm{a}}$ & $0.09 \pm 0.00^{\mathrm{a}}$ \\
\hline C18:3n-3 & $2.82 \pm 0.12^{\mathrm{a}}$ & $1.82 \pm 0.07^{\mathrm{a}}$ & $1.85 \pm 0.07^{\mathrm{a}}$ & $2.31 \pm 0.09^{a}$ & $2.35 \pm 0.09^{a}$ & $3.64 \pm 0.54^{\mathrm{a}}$ & $2.05 \pm 0.10^{\mathrm{a}}$ & $9.34 \pm 0.75^{b}$ & $11.27 \pm 0.91^{\mathrm{b}}$ \\
\hline$C 20: 2 n-6$ & $1.06 \pm 0.14^{\mathrm{a}}$ & $1.74 \pm 0.24^{\mathrm{b}}$ & $1.59 \pm 0.08^{\mathrm{ab}}$ & $1.69 \pm 0.04^{\mathrm{ab}}$ & $1.62 \pm 0.07^{\mathrm{ab}}$ & $1.86 \pm 0.05^{b}$ & $2.64 \pm 0.16^{\mathrm{c}}$ & $1.82 \pm 0.14^{b}$ & $1.22 \pm 0.10^{\mathrm{ab}}$ \\
\hline$C 20: 3 n-6$ & $0.04 \pm 0.02^{\mathrm{a}}$ & $0.08 \pm 0.00^{\mathrm{a}}$ & $0.05 \pm 0.01^{\mathrm{a}}$ & $0.13 \pm 0.05^{\mathrm{ab}}$ & $0.23 \pm 0.02^{b c}$ & $0.12 \pm 0.01^{\mathrm{ab}}$ & $0.14 \pm 0.00^{\mathrm{abc}}$ & $0.25 \pm 0.03^{c}$ & $0.14 \pm 0.00^{\mathrm{abc}}$ \\
\hline C22:1n-9 & ND & ND & ND & ND & ND & ND & ND & ND & ND \\
\hline$C 20: 3 n-3$ & $1.46 \pm 0.12^{\mathrm{b}}$ & $0.97 \pm 0.08^{\mathrm{a}}$ & $0.82 \pm 0.07^{\mathrm{a}}$ & $0.97 \pm 0.12^{\mathrm{a}}$ & $0.96 \pm 0.02^{\mathrm{a}}$ & $1.05 \pm 0.07^{\mathrm{a}}$ & $0.90 \pm 0.04^{\mathrm{a}}$ & $2.27 \pm 0.08^{\mathrm{b}}$ & $2.23 \pm 0.04^{\mathrm{b}}$ \\
\hline$C 20: 4 n-6$ & $0.41 \pm 0.19^{\mathrm{ab}}$ & $0.28 \pm 0.05^{\mathrm{ab}}$ & $0.07 \pm 0.01^{\mathrm{a}}$ & $0.23 \pm 0.09^{\mathrm{ab}}$ & $0.27 \pm 0.03^{\mathrm{ab}}$ & $0.32 \pm 0.05^{\mathrm{ab}}$ & $0.15 \pm 0.06^{\mathrm{a}}$ & $0.79 \pm 0.29^{b c}$ & $1.13 \pm 0.11^{\mathrm{c}}$ \\
\hline$C 20: 4 n-3$ & $0.39 \pm 0.02$ & $0.44 \pm 0.03$ & $0.22 \pm 0.11$ & $0.30 \pm 0.00$ & $0.24 \pm 0.01$ & $0.16 \pm 0.06$ & $0.30 \pm 0.12$ & $0.21 \pm 0.06$ & $0.25 \pm 0.05$ \\
\hline $\mathrm{C} 24: 0$ & $3.27 \pm 0.38^{\mathrm{b}}$ & $2.36 \pm 0.05^{\mathrm{a}}$ & $2.01 \pm 0.04^{\mathrm{a}}$ & $1.86 \pm 0.14^{\mathrm{a}}$ & $1.77 \pm 0.04^{\mathrm{a}}$ & $2.10 \pm 0.19^{\mathrm{a}}$ & $1.80 \pm 0.04^{\mathrm{a}}$ & $1.75 \pm 0.12^{\mathrm{a}}$ & $1.87 \pm 0.08^{\mathrm{a}}$ \\
\hline$C 20: 5 n-3$ & $0.75 \pm 0.13^{\mathrm{ab}}$ & $0.42 \pm 0.03^{\mathrm{a}}$ & $1.28 \pm 0.38^{\mathrm{b}}$ & $0.45 \pm 0.09^{a}$ & $0.36 \pm 0.02^{\mathrm{a}}$ & $0.20 \pm 0.05^{\mathrm{a}}$ & $0.32 \pm 0.06^{\mathrm{a}}$ & $0.37 \pm 0.05^{\mathrm{a}}$ & $0.29 \pm 0.03^{\mathrm{a}}$ \\
\hline$C 22: 5 n-3$ & $2.79 \pm 0.23^{\mathrm{c}}$ & $1.66 \pm 0.05^{\mathrm{b}}$ & $0.96 \pm 0.24^{\mathrm{ab}}$ & $1.35 \pm 0.07^{\mathrm{ab}}$ & $1.42 \pm 0.11^{\mathrm{ab}}$ & $0.53 \pm 0.16^{\mathrm{a}}$ & $1.32 \pm 0.25^{\mathrm{ab}}$ & $1.00 \pm 0.21^{\mathrm{ab}}$ & $1.02 \pm 0.21^{\mathrm{ab}}$ \\
\hline
\end{tabular}




\begin{tabular}{|c|c|c|c|c|c|c|c|c|c|}
\hline$C 22: 6 n-3$ & $25.34 \pm 1.13^{\mathrm{c}}$ & $18.94 \pm 0.92^{\mathrm{b}}$ & $16.95 \pm 0.52^{\mathrm{ab}}$ & $16.32 \pm 1.33^{\mathrm{ab}}$ & $16.17 \pm 0.19^{\mathrm{ab}}$ & $16.84 \pm 0.42^{\mathrm{ab}}$ & $\begin{array}{l}16.78 \\
0.86^{\mathrm{ab}}\end{array}$ & $16.41 \pm 0.20^{\mathrm{ab}}$ & $14.82 \pm 0.94^{\mathrm{a}}$ \\
\hline$\Sigma \mathrm{SFA}^{3}$ & $\begin{array}{l}36.34 \\
1.48^{\mathrm{ab}}\end{array}$ & $37.19 \pm 1.75^{\mathrm{b}}$ & $35.03 \pm 1.27^{\mathrm{ab}}$ & $30.30 \pm 1.33^{\mathrm{ab}}$ & $29.09 \pm 1.10^{\mathrm{a}}$ & $29.67 \pm 0.29^{\mathrm{ab}}$ & $29.48 \pm 1.77^{\mathrm{a}}$ & $33.01 \pm 1.07^{\mathrm{ab}}$ & $\begin{array}{l}33.12 \\
2.72^{\mathrm{ab}}\end{array}$ \\
\hline$\Sigma \mathrm{MUFA}^{4}$ & $18.40 \pm 1.05^{\mathrm{a}}$ & $22.27 \pm 0.29^{\mathrm{ab}}$ & $27.10 \pm 1.33^{\mathrm{cd}}$ & $32.06 \pm 0.37^{\mathrm{e}}$ & $34.47 \pm 1.03^{\mathrm{e}}$ & $30.66 \pm 1.61^{\mathrm{de}}$ & $\begin{array}{l}24.38 \\
0.18^{\mathrm{bc}}\end{array}$ & $18.42 \pm 0.71^{\mathrm{a}}$ & $\begin{array}{l}20.09 \\
1.02^{\mathrm{ab}}\end{array}$ \\
\hline$\Sigma \mathrm{PUFA}^{5}$ & $\begin{array}{l}43.03 \\
0.93^{\mathrm{bcd}}\end{array}$ & $\begin{array}{l}39.69 \\
1.88^{\text {abcd }}\end{array}$ & $\begin{array}{l}37.41 \\
1.00^{\mathrm{abc}}\end{array} \quad \pm$ & $36.06 \pm 2.08^{\mathrm{ab}}$ & $35.28 \pm 0.75^{\mathrm{a}}$ & $\begin{array}{l}38.87 \\
1.11^{\mathrm{abcd}}\end{array}$ & $\begin{array}{l}44.66 \\
1.64^{\mathrm{cd}}\end{array}$ & $46.23 \pm 0.62^{\mathrm{d}}$ & $\begin{array}{l}45.05 \\
2.65^{\mathrm{cd}}\end{array}$ \\
\hline$\Sigma$ n-6 PUFA ${ }^{6}$ & $9.47 \pm 0.53^{\mathrm{a}}$ & $15.46 \pm 0.84^{b}$ & $15.33 \pm 0.28^{\mathrm{b}}$ & $14.36 \pm 0.46^{\mathrm{b}}$ & $13.78 \pm 0.44^{\mathrm{b}}$ & $16.43 \pm 0.61^{b}$ & $23.00 \pm 0.38^{\mathrm{b}}$ & $16.64 \pm 0.35^{\mathrm{b}}$ & $15.17 \pm 0.99^{b}$ \\
\hline$\Sigma \mathrm{n}-3 \mathrm{PUFA}^{7}$ & $33.56 \pm 0.99^{c}$ & $24.23 \pm 1.07^{\mathrm{ab}}$ & $22.08 \pm 1.24^{\mathrm{a}}$ & $21.70 \pm 1.64^{\mathrm{a}}$ & $21.50 \pm 0.32^{\mathrm{a}}$ & $22.44 \pm 0.50^{\mathrm{a}}$ & $21.67 \pm 1.33^{\mathrm{a}}$ & $29.60 \pm 0.33^{b c}$ & $29.88 \pm 1.66^{\mathrm{c}}$ \\
\hline$\Sigma \mathrm{HUFA}^{8}$ & $\begin{array}{l}32.24 \\
0.97^{\mathrm{b}}\end{array} \quad \pm$ & $24.52 \pm 1.21^{\mathrm{a}}$ & $21.93 \pm 1.37^{\mathrm{a}}$ & $21.44 \pm 1.40^{\mathrm{a}}$ & $21.27 \pm 0.32^{\mathrm{a}}$ & $21.09 \pm 0.05^{\mathrm{a}}$ & $22.54 \pm 1.38^{\mathrm{a}}$ & $23.11 \pm 0.66^{\mathrm{a}}$ & $21.11 \pm 1.07^{\mathrm{a}}$ \\
\hline$n-3 / n-6$ & $3.57 \pm 0.27^{\mathrm{d}}$ & $1.57 \pm 0.03^{\mathrm{bc}}$ & $1.44 \pm 0.10^{\mathrm{ab}}$ & $1.51 \pm 0.07^{\mathrm{bc}}$ & $1.56 \pm 0.03^{b c}$ & $1.36 \pm 0.02^{\mathrm{ab}}$ & $0.94 \pm 0.05^{\mathrm{a}}$ & $1.78 \pm 0.03^{b c}$ & $1.97 \pm 0.02^{\mathrm{b}}$ \\
\hline
\end{tabular}

Notes: Values are mean $\pm \mathrm{SE}(\mathrm{n}=3)$. Mean values in the same row with different superscripts are significantly different $(P<0.05)$. ND, no detected.

${ }^{1} \Sigma$ SFA is the sum of saturated fatty acids; ${ }^{2} \Sigma$ MUFA is the sum of monounsaturated fatty acids; ${ }^{3} \Sigma P U F A$ is the sum of polyunsaturated fatty acids; ${ }^{4} \Sigma \mathrm{n}-6$ PUFA is the sum of n-6 polyunsaturated fatty acids; ${ }^{5} \Sigma \mathrm{n}-3$ PUFA is the sum of n-3 polyunsaturated fatty acids; ${ }^{6} \Sigma$ LC-PUFA is the sum of long-chain polyunsaturated fatty acids. FO, fish oil; CO, coconut oil; PO, palm oil; OTO, oil-tea camellia oil; OO, olive oil; CNO, canola oil; PNO, peanut oil; LO, linseed oil; PFO, perilla oil. 
Supplementary Table 6. The fatty acid composition of neutral lipid in ventral muscle (\% total fatty acids).

\begin{tabular}{|c|c|c|c|c|c|c|c|c|c|}
\hline \multirow[t]{2}{*}{ Parameter } & \multicolumn{9}{|c|}{ Dietary treatment } \\
\hline & FO & $\mathrm{CO}$ & $\mathrm{PO}$ & OTO & $\mathrm{OO}$ & $\mathrm{CNO}$ & PNO & LO & PFO \\
\hline C12:0 & ND & ND & ND & ND & ND & ND & ND & ND & ND \\
\hline $\mathrm{C} 14: 0$ & ND & ND & ND & ND & ND & ND & ND & ND & ND \\
\hline C16:0 & $\begin{array}{l}21.98 \\
1.29^{\mathrm{ab}}\end{array}$ & $22.34 \pm 1.46^{\mathrm{b}}$ & $18.97 \pm 0.61^{\mathrm{a}}$ & $17.08 \pm 1.22^{\mathrm{a}}$ & $17.73 \pm 0.74^{\mathrm{ab}}$ & $17.23 \pm 0.82^{\mathrm{ab}}$ & $\begin{array}{l}19.37 \\
0.74^{\mathrm{ab}}\end{array}$ & $16.85 \pm 1.06^{\mathrm{a}}$ & $\begin{array}{l}18.72 \\
1.21^{\mathrm{ab}}\end{array}$ \\
\hline $\mathrm{C} 16: 1^{1}$ & $1.73 \pm 0.38^{\mathrm{ab}}$ & $2.33 \pm 0.42^{b}$ & $1.09 \pm 0.14^{\mathrm{ab}}$ & $1.60 \pm 0.49^{\mathrm{ab}}$ & $1.86 \pm 0.48^{\mathrm{ab}}$ & $0.56 \pm 0.30^{\mathrm{a}}$ & $0.91 \pm 0.17^{\mathrm{ab}}$ & $0.60 \pm 0.09^{\mathrm{a}}$ & $0.96 \pm 0.25^{\mathrm{ab}}$ \\
\hline C18:0 & $11.15 \pm 1.34$ & $11.62 \pm 0.60$ & $9.64 \pm 0.21$ & $8.96 \pm 0.90$ & $8.91 \pm 0.17$ & $8.89 \pm 0.67$ & $10.80 \pm 0.17$ & $10.71 \pm 0.47$ & $9.50 \pm 0.09$ \\
\hline $\mathrm{C} 18: 1^{2}$ & $16.25 \pm 1.68^{\mathrm{a}}$ & $\begin{array}{l}22.43 \\
0.92^{\text {bcd }}\end{array}$ & $25.99 \pm 1.75^{\mathrm{de}}$ & $35.45 \pm 1.52^{f}$ & $35.54 \pm 0.54^{\mathrm{f}}$ & $28.70 \pm 0.60^{\mathrm{e}}$ & $\begin{array}{l}24.34 \\
1.23^{\text {cde }}\end{array}$ & $18.12 \pm 1.40^{\mathrm{ab}}$ & $\begin{array}{l}19.30 \\
0.23^{\mathrm{abc}}\end{array}$ \\
\hline C18:2n-6 & $7.78 \pm 0.42^{\mathrm{a}}$ & $\begin{array}{l}14.44 \\
0.13^{\text {bcd }}\end{array}$ & $16.62 \pm 0.40^{\mathrm{de}}$ & $13.90 \pm 0.81^{b c}$ & $12.32 \pm 0.55^{\mathrm{a}}$ & $18.40 \pm 0.57^{\mathrm{e}}$ & $22.43 \pm 0.53^{\mathrm{f}}$ & $\begin{array}{l}15.87 \\
0.58^{\text {cde }}\end{array}$ & $\begin{array}{l}13.28 \\
0.44^{\mathrm{bc}}\end{array}$ \\
\hline $\mathrm{C} 20: 0$ & $0.41 \pm 0.01^{\mathrm{b}}$ & $0.45 \pm 0.06^{\mathrm{b}}$ & $0.24 \pm 0.03^{\mathrm{a}}$ & $0.21 \pm 0.01^{\mathrm{a}}$ & $0.22 \pm 0.01^{\mathrm{a}}$ & $0.19 \pm 0.02^{\mathrm{a}}$ & $0.22 \pm 0.02^{\mathrm{a}}$ & $0.24 \pm 0.02^{\mathrm{a}}$ & $0.24 \pm 0.02^{\mathrm{a}}$ \\
\hline C20:1n-9 & $0.10 \pm 0.01$ & $0.11 \pm 0.02$ & $0.10 \pm 0.01$ & $0.09 \pm 0.01$ & $0.08 \pm 0.00$ & $0.06 \pm 0.02$ & $0.10 \pm 0.02$ & $0.10 \pm 0.01$ & $0.09 \pm 0.01$ \\
\hline C18:3n-3 & $2.63 \pm 0.16^{\mathrm{ab}}$ & $1.26 \pm 0.19^{\mathrm{a}}$ & $1.60 \pm 0.07^{\mathrm{a}}$ & $1.69 \pm 0.04^{\mathrm{a}}$ & $1.78 \pm 0.03^{\mathrm{ab}}$ & $3.67 \pm 0.41^{\mathrm{b}}$ & $1.73 \pm 0.05^{\mathrm{a}}$ & $11.67 \pm 0.75^{\mathrm{c}}$ & $12.97 \pm 0.72^{\mathrm{c}}$ \\
\hline$C 20: 2 n-6$ & $0.72 \pm 0.11^{\mathrm{a}}$ & $0.72 \pm 0.02^{\mathrm{a}}$ & $1.15 \pm 0.36^{\mathrm{ab}}$ & $0.97 \pm 0.22^{\mathrm{ab}}$ & $0.76 \pm 0.18^{\mathrm{ab}}$ & $1.70 \pm 0.10^{\mathrm{bc}}$ & $2.12 \pm 0.11^{\mathrm{c}}$ & $0.75 \pm 0.17^{\mathrm{a}}$ & $1.18 \pm 0.25^{\mathrm{abc}}$ \\
\hline$C 20: 3 n-6$ & $0.07 \pm 0.01$ & $0.08 \pm 0.00$ & $0.06 \pm 0.01$ & $0.09 \pm 0.02$ & $0.09 \pm 0.02$ & $0.08 \pm 0.00$ & $0.11 \pm 0.01$ & $0.09 \pm 0.01$ & $0.10 \pm 0.01$ \\
\hline $\mathrm{C} 22: 1 \mathrm{n}-9$ & ND & ND & ND & ND & ND & ND & ND & ND & ND \\
\hline$C 20: 3 n-3$ & $\begin{array}{l}1.45 \\
0.18^{\text {cde }}\end{array}$ & $0.49 \pm 0.15^{\mathrm{ab}}$ & $0.86 \pm 0.07^{\mathrm{abc}}$ & $1.38 \pm 0.23^{\text {bcde }}$ & $1.20 \pm 0.21^{\mathrm{bcd}}$ & $1.50 \pm 0.27^{\text {cde }}$ & $0.13 \pm 0.01^{\mathrm{a}}$ & $2.24 \pm 0.25^{\mathrm{e}}$ & $1.94 \pm 0.20^{\mathrm{de}}$ \\
\hline$C 20: 4 n-6$ & $0.15 \pm 0.01^{\mathrm{a}}$ & $0.09 \pm 0.01^{\mathrm{a}}$ & $0.08 \pm 0.01^{\mathrm{a}}$ & $0.09 \pm 0.03^{\mathrm{a}}$ & $0.11 \pm 0.02^{\mathrm{a}}$ & $0.09 \pm 0.01^{\mathrm{a}}$ & $1.44 \pm 0.34^{\mathrm{b}}$ & $0.09 \pm 0.01^{\mathrm{a}}$ & $0.08 \pm 0.00^{\mathrm{a}}$ \\
\hline$C 20: 4 n-3$ & $0.33 \pm 0.02^{\mathrm{c}}$ & $0.14 \pm 0.01^{\mathrm{b}}$ & $0.13 \pm 0.00^{\mathrm{ab}}$ & $0.12 \pm 0.01^{\mathrm{ab}}$ & $0.13 \pm 0.02^{\mathrm{ab}}$ & $0.10 \pm 0.01^{\mathrm{ab}}$ & $0.08 \pm 0.01^{\mathrm{a}}$ & $0.14 \pm 0.01^{\mathrm{ab}}$ & $0.13 \pm 0.01^{\mathrm{ab}}$ \\
\hline $\mathrm{C} 24: 0$ & $4.80 \pm 0.45^{\mathrm{b}}$ & $2.69 \pm 0.80^{\mathrm{ab}}$ & $2.65 \pm 0.15^{\mathrm{ab}}$ & $2.39 \pm 0.62^{\mathrm{a}}$ & $2.00 \pm 0.44^{\mathrm{a}}$ & $2.47 \pm 0.60^{\mathrm{a}}$ & $1.30 \pm 0.27^{\mathrm{a}}$ & $2.93 \pm 0.19^{\mathrm{ab}}$ & $3.35 \pm 0.21^{\mathrm{ab}}$ \\
\hline$C 20: 5 n-3$ & $0.52 \pm 0.10$ & $0.60 \pm 0.07$ & $0.55 \pm 0.02$ & $0.56 \pm 0.08$ & $0.57 \pm 0.06$ & $0.43 \pm 0.06$ & $0.53 \pm 0.06$ & $0.45 \pm 0.04$ & $0.48 \pm 0.03$ \\
\hline
\end{tabular}




\begin{tabular}{|c|c|c|c|c|c|c|c|c|c|}
\hline$C 22: 5 n-3$ & $0.51 \pm 0.03^{b}$ & $0.53 \pm 0.10^{b}$ & $0.40 \pm 0.02^{\mathrm{ab}}$ & $0.46 \pm 0.04^{\mathrm{ab}}$ & $0.42 \pm 0.08^{\mathrm{ab}}$ & $0.21 \pm 0.04^{\mathrm{a}}$ & $0.28 \pm 0.08^{\mathrm{ab}}$ & $0.39 \pm 0.03^{\mathrm{ab}}$ & $0.35 \pm 0.04^{\mathrm{ab}}$ \\
\hline$C 22: 6 n-3$ & $28.05 \pm 1.72^{\mathrm{c}}$ & $18.80 \pm 1.25^{\mathrm{b}}$ & $19.14 \pm 1.22^{\mathrm{b}}$ & $15.04 \pm 0.72^{\mathrm{ab}}$ & $15.04 \pm 0.72^{\mathrm{ab}}$ & $15.02 \pm 1.00^{\mathrm{ab}}$ & $12.22 \pm 0.87^{\mathrm{a}}$ & $15.92 \pm 0.39^{\mathrm{ab}}$ & $\begin{array}{l}15.41 \\
0.85^{\mathrm{ab}}\end{array}$ \\
\hline$\Sigma \mathrm{SFA}^{3}$ & $38.34 \pm 0.14^{\mathrm{c}}$ & $37.10 \pm 1.59^{b c}$ & $31.50 \pm 0.60^{\mathrm{ab}}$ & $28.64 \pm 1.64^{\mathrm{a}}$ & $28.85 \pm 0.92^{\mathrm{a}}$ & $28.77 \pm 1.22^{\mathrm{a}}$ & $\begin{array}{l}31.70 \\
0.62^{\mathrm{ab}}\end{array}$ & $30.72 \pm 1.38^{\mathrm{ab}}$ & $\begin{array}{l}31.81 \\
1.51^{\mathrm{ab}}\end{array}$ \\
\hline$\Sigma$ MUFA $^{4}$ & $18.09 \pm 1.31^{\mathrm{a}}$ & $\begin{array}{l}24.87 \\
1.13^{\mathrm{bcd}}\end{array}$ & $27.17 \pm 1.87^{d}$ & $37.14 \pm 1.63^{\mathrm{e}}$ & $37.49 \pm 0.49^{\mathrm{e}}$ & $29.32 \pm 0.83^{\mathrm{d}}$ & $\begin{array}{l}25.34 \\
1.24^{\text {cd }}\end{array}$ & $18.82 \pm 1.35^{\mathrm{ab}}$ & $\begin{array}{l}20.34 \\
0.13^{\mathrm{abc}}\end{array}$ \\
\hline$\Sigma \mathrm{PUFA}^{5}$ & $\begin{array}{l}42.22 \\
1.22^{\text {bcd }}\end{array}$ & $37.16 \pm 1.29^{\mathrm{ab}}$ & $40.58 \pm 1.48^{b c}$ & $33.47 \pm 0.81^{\mathrm{a}}$ & $32.41 \pm 0.98^{\mathrm{a}}$ & $41.20 \pm 2.04^{\mathrm{bc}}$ & $\begin{array}{l}41.07 \\
0.75^{\mathrm{bc}}\end{array}$ & $47.61 \pm 0.27^{\mathrm{d}}$ & $\begin{array}{l}45.92 \\
1.56^{\mathrm{cd}}\end{array}$ \\
\hline$\Sigma$ n-6 PUFA ${ }^{6}$ & $8.71 \pm 0.51^{\mathrm{a}}$ & $15.33 \pm 0.15^{b c}$ & $17.92 \pm 0.74^{\mathrm{de}}$ & $15.04 \pm 0.69^{\mathrm{bc}}$ & $13.28 \pm 0.42^{b}$ & $20.28 \pm 0.57^{\mathrm{e}}$ & $26.11 \pm 0.23^{\mathrm{b}}$ & $16.81 \pm 0.72^{\mathrm{cd}}$ & $\begin{array}{l}14.63 \\
0.65^{\mathrm{bc}}\end{array}$ \\
\hline$\Sigma \mathrm{n}-3 \mathrm{PUFA}^{7}$ & $33.50 \pm 1.72^{c}$ & $21.82 \pm 1.43^{b}$ & $22.66 \pm 1.13^{b}$ & $18.42 \pm 1.37^{\mathrm{ab}}$ & $19.14 \pm 0.76^{\mathrm{ab}}$ & $20.92 \pm 1.69^{\mathrm{ab}}$ & $14.97 \pm 0.94^{\mathrm{a}}$ & $30.80 \pm 0.76^{\mathrm{c}}$ & $31.29 \pm 0.94^{c}$ \\
\hline$\Sigma \mathrm{HUFA}^{8}$ & $\begin{array}{l}31.80 \\
1.75^{\mathrm{b}}\end{array} \quad \pm$ & $21.45 \pm 1.25^{\mathrm{a}}$ & $22.36 \pm 1.38^{\mathrm{a}}$ & $17.88 \pm 1.59^{\mathrm{a}}$ & $18.31 \pm 0.59^{\mathrm{a}}$ & $18.31 \pm 0.59^{\mathrm{a}}$ & $16.91 \pm 1.00^{\mathrm{a}}$ & $20.07 \pm 0.47^{\mathrm{a}}$ & $19.67 \pm 1.27^{\mathrm{a}}$ \\
\hline$n-3 / n-6$ & $3.90 \pm 0.45^{\mathrm{d}}$ & $1.42 \pm 0.11^{\mathrm{abc}}$ & $1.27 \pm 0.07^{\mathrm{ab}}$ & $1.24 \pm 0.14^{\mathrm{ab}}$ & $1.44 \pm 0.06^{\mathrm{bc}}$ & $1.03 \pm 0.08^{\mathrm{ab}}$ & $0.57 \pm 0.04^{\mathrm{a}}$ & $1.85 \pm 0.12^{b c}$ & $2.14 \pm 0.04^{\mathrm{c}}$ \\
\hline
\end{tabular}

Notes: Values are mean $\pm \mathrm{SE}(\mathrm{n}=3)$. Mean values in the same row with different superscripts are significantly different $(P<0.05)$. ND, no detected.

${ }^{1} \Sigma$ SFA is the sum of saturated fatty acids; ${ }^{2} \Sigma$ MUFA is the sum of monounsaturated fatty acids; ${ }^{3} \Sigma$ PUFA is the sum of polyunsaturated fatty acids; ${ }^{4} \Sigma \mathrm{n}-6$ PUFA is the sum of n-6 polyunsaturated fatty acids; ${ }^{5} \Sigma \mathrm{n}-3$ PUFA is the sum of n-3 polyunsaturated fatty acids; ${ }^{6} \Sigma$ LC-PUFA is the sum of long-chain polyunsaturated fatty acids. FO, fish oil; CO, coconut oil; PO, palm oil; OTO, oil-tea camellia oil; OO, olive oil; CNO, canola oil; PNO, peanut oil; LO, linseed oil; PFO, perilla oil. 